\section{Camargo Foundation}

1, Avenue Jermini, F-13260 Cassis, France.

Tel: $\quad$ (33) 442011311

Email: apply@camargofoundation.org

Website: www.camargofoundation.org

Contact: Cynthia A. Gehrig, President

The Camargo Foundation is a residential center offering programming in the humanities and the arts.

\section{The Camargo Core Program}

Purpose: The Camargo Foundation, located in Cassis, France, and founded by artist and philanthropist Jerome Hill, is a residential center offering programming in the Arts and Humanities. It offers time and space in a contemplative environment to think, create, and connect. The Foundation encourages the visionary work of artists, scholars, and thinkers in the Arts and Humanities. The Camargo Core Program is the historical and flagship program of the Camargo Foundation. Each year an international call is launched through which 18 fellows (9 artists and 9 scholars/thinkers) are selected. The Camargo Core Program offers time and space in a contemplative environment to think, create, and connect. By supporting groundbreaking research and experimentation, it contributes to the visionary work of artists, scholars and thinkers in the Arts and Humanities. By encouraging multidisciplinary and interdisciplinary approaches, it intends to foster connections between research and creation

Eligibility: Scholars should be connected to the Arts and Humanities working on French and Francophone cultures, or cross-cultural studies that engage the cultures and influences of the Mediterranean region. To be eligible for a fellowship in the "Scholars" category, applicants are

(C) Springer Nature Limited 2020

Palgrave Macmillan (ed.), The Grants Register 2021,

https://doi.org/10.1057/978-1-349-95988-4 expected either to hold a PhD and a record of post-doctoral scholarship, or to be $\mathrm{PhD}$ candidates completing the final stages of research for, or writing of, their dissertation

Level of Study: Doctorate, Postdoctorate, Postgraduate, Professional development, Research, Foundation programme

Type: Residential fellowships

Value: A stipend of $€ 250$ per week is available, as is funding for basic transportation to and from Cassis for the Fellow for the residency. In the case of air travel, basic coach class booked far in advance is covered

Frequency: Annual

Country of Study: France

Application Procedure: The call for applications for the Camargo Core Program for the upcoming years will be open in summer years. More information will be available on www. camargofoundation.org

No. of awards offered: 1038

Funding: Government, Private, Foundation, Trusts, Individuals

No. of awards given last year: 18

No. of applicants last year: 1038

Additional Information: More information is available on camargofoundation.org/programs/camargo-core-program/

\section{Canada Council for the Arts}

150 Elgin St., PO Box 1047, Ottawa, ON, K1P 5V8, Canada.

Tel: (1) 8002635588 or (1) 6135664414

Email: info@canadacouncil.ca

Website: www.canadacouncil.ca

Contact: Martin, Program Officer

The Canada Council for the Arts is a national agency that provides grants and services to professional Canadian artists and art organizations in dance, media arts, music, theatre, writing and publishing, inter-arts and the visual arts. 


\section{John G. Diefenbaker Award}

Purpose: The John G. Diefenbaker Award is funded by an endowment given to the Canada Council for the Arts by the Government of Canada. The endowment, announced by Prime Minister Brian Mulroney during his visit to Germany in the spring of 1991, honours the memory of former Prime Minister John G. Diefenbaker. The award is given annually, and it enables a distinguished German scholar to do research in Canada, which may include brief periods in the United States. The spirit of the award is to encourage exchange between scholarly communities in Canada and Germany

Eligibility: Candidates may not apply for this award: they must be nominated by a department within a host university or research institute in Canada. This award is open to German scholars who have demonstrated outstanding ability, especially through a substantial publication record over several years. The award is offered in support of research in any of the disciplines of the social sciences and humanities. Candidates must be German citizens with a contractual or working relationship with an academic institution in Germany. They must have a sound working knowledge of at least one of Canada's two official languages

Value: Up to US $\$ 95,000$

Country of Study: Any country

Application Procedure: Check website for more details Closing Date: 1 November

Additional Information: canadacouncil.ca/funding/prizes/ john-g-diefenbaker-award

\section{For further information contact:}

Email: luiza.pereira@canadacouncil.ca

\section{John Hobday Awards in Arts Management}

Purpose: Established through a donation of $\mathrm{C} \$ 1,000,000$ from The Samuel and Saidye Bronfman Family Foundation to the Canada Council for the Arts, the awards recognize outstanding established and mid-career arts managers in Canadian professional arts organizations. Arts managers from any artistic discipline supported by the Canada Council may apply for the awards, which are intended for professional development, mentoring and related purposes

Eligibility: Applicants should be a Canadian citizen or have permanent resident status, as defined by Citizenship and Immigration Canada. You do not need to be living in Canada when you apply. Applicants should have a minimum of 10 years' experience (not necessarily continuous years) as a professional arts manager

Level of Study: Postgraduate

Type: Cash prize

Value: Two awards of C $\$ 10,000$ each may be given annually
Frequency: Annual

Country of Study: Canada

Closing Date: 30 September

Additional Information: canadacouncil.ca/funding/prizes/ john-hobday-awards-in-arts-management

\section{For further information contact:}

Email: sarah.brown@canadacouncil.ca

\section{Killam Research Fellowships}

Purpose: To support Canadian scholars of exceptional ability engaged in advanced research projects

Eligibility: Open to Canadian citizens or permanent residents of Canada. Killam Research Fellowships are aimed at established scholars who have demonstrated outstanding ability through substantial publications in their fields over a period of several years. Killam Research Fellows are expected to continue contributing to the Canadian research community after they have completed their fellowship project Level of Study: Postgraduate

Type: Fellowship

Value: C\$70,000 per year, paid to the university or research institution which employs the fellow

Length of Study: 2 years

Frequency: Annual

Country of Study: Any country

Application Procedure: There are no hard copy application forms: applicants must submit their requests through the Canada Council's online application system at killam.canadacouncil.ca

Closing Date: 15 May

Funding: Private

Contributor: Killam Trust

Additional Information: Please check at canadacouncil.ca/ en/council/grants/find-a-grant canadacouncil.ca/funding/ prizes/killam-research-fellowships for further information

\section{For further information contact:}

Email: killam.canadacouncil.ca

\section{Musical Instrument Bank}

Purpose: Every 3 years, talented Canadian classical musicians compete for the chance to borrow legendary instruments from the Canada Council's Musical Instrument Bank (MIB). The competition is intense and is decided by a jury of professional musicians and peers. Musicians who win the competition are often invited to perform with their instruments on some of the world's most celebrated stages. The MIB includes over $20 \mathrm{mag}$ nificent instruments worth a total of over $\mathrm{C} \$ 41,000,000$. These violins, cellos and bows, created by such master craftsmen as 
Stradivari, Gagliano and Pressenda, have been donated or lent to the MIB since it was created in 1985

Eligibility: For eligibility criteria, the application form and further information on this competition, see the Canada Council's Musical Instrument Bank Guidelines and the Musical Instrument Bank website.

Level of Study: Doctorate

Value: $C \$ 100,000$

Length of Study: 3 years

Country of Study: Canada

Closing Date: 1 April

Additional Information: canadacouncil.ca/funding/prizes/ musical-instrument-bank

\section{For further information contact:}

Tel: (1) 4032443074

\section{Prix de Rome in Architecture for Emerging Practitioners}

Purpose: The Canada Council for the Arts Prix de Rome in Architecture for Emerging Practitioners is awarded to a recent graduate of a Canadian school of architecture who demonstrates exceptional potential in contemporary architectural design

Eligibility: Applicants must be a Canadian citizen or have Permanent Resident status, as defined by Citizenship and Immigration Canada

Value: The prize is $\mathrm{C} \$ 34,000$, to contribute towards the costs of the proposed program of work and related travels, and of the proposed public presentation

Country of Study: Any country

Closing Date: 1 October

Additional Information: Should have received a professional Bachelor or Master degree from a Canadian school of architecture that is certified by the Canadian Architectural Certification Board within 14 months prior to the deadline for submitting applications canadacouncil.ca/funding/prizes/ prix-de-rome-in-architecture-for-emerging-practitioners

\section{For further information contact:}

Email: sarah.brown@canadacouncil.ca

\section{Canadian Association of Broadcasters (CAB)}

770-45 O’Connor St., Ottawa, ON K1P 1A4, Canada.

Tel: $\quad$ (1) 6132334035

Email: cab@cab-acr.ca
Website: www.cab-acr.ca
Contact: Vanessa Dawson, Special Events and Projects Co-ordinator

The Canadian Association of Broadcasters (CAB) is the collective voice of Canada's private radio and television stations and speciality services. The CAB develops industry-wide strategic plans, works to improve the financial health of the industry, and promotes private broadcasting's role as Canada's leading programmer and local service provider.

\section{Horatio Alger Association Canadian Scholarships}

Purpose: Horatio Alger Association Canadian Scholarships are funded through the generosity of the Association's Members Eligibility: 1. Be graduating high school (or be in the final year of CEGEP). 2. Exhibit a strong commitment to pursue and complete a bachelor's degree program at an accredited university 3. Demonstrate critical financial need (C\$65,000 or less annual net income per family is required) 4 . Be involved in co-curricular and community service activities 5. Display integrity and perseverance in overcoming adversity 6 . Maintain a minimum grade percentage of 65. 7. Attend high school (or CEGEP) and reside in Canada 8. Be Canadian citizens

Level of Study: Graduate

Type: Scholarship

Value: $C \$ 5,000$

Frequency: Annual

Country of Study: Canada

Closing Date: 25 October

Funding: Private

Additional Information: scholartree.ca/scholarship/horatioalger-canadian-scholarships/ygaPZSxKV

\section{For further information contact:}

Email: scholarships@horatioalger.org

\section{Canadian Blood Services (CBS)}

1800 Alta Vista Drive, Ottawa, ON K1G 4J5, Canada.

Tel: $\quad$ (1) 6137392300

Email:_onematch@blood.ca

Website: www.bloodservices.ca

Canadian Blood Services (CBS) is a non-profit, charitable organization whose sole mission is to manage the blood system for Canadians. CBS collects approx. 900,000 units of blood annually and processes it into components and products that are administered to thousands of patients each year. 


\section{Canadian Blood Services Graduate Fellowship Program}

Purpose: To attract and support young investigators to initiate or continue training in the field of blood or blood products research Eligibility: Open to graduate students who are undertaking full-time research training leading to a PhD degree. Students registering solely for a Master's degree will not be considered and only those demonstrating acceptance into a $\mathrm{PhD}$ programme will receive continued support. Candidates must have completed sufficient academic work to be admitted in good standing to a graduate school by the time the award is to take effect, or be already engaged in a $\mathrm{PhD}$ programme. Applicants possessing a medical degree but not licensed to practice medicine in Canada are eligible to apply for this award providing they meet the above criteria

Level of Study: Graduate

Type: Fellowship

Value: C\$25,000 per annum with an additional travel allowance of C\$1,000 per year

Length of Study: 4 years

Country of Study: Canada

Application Procedure: Candidates are required to submit a completed application form (GFP-01) that is available either from the website, from or the main address

No. of awards offered: 15

Closing Date: 15 November

Funding: Government

No. of awards given last year: 7

No. of applicants last year: 15

Additional Information: Please check at www.blood.ca/en/ research/funding-programs blood.ca/en/research/our-researchactivities/our-research-funding-opportunities/canadian-bloodservices-graduate-fellowship-program

\section{For further information contact:}

Program Assistant, R\&D, Canadian Blood Services, 1800 Alta Vista Drive, Ottawa, ON K1G 4J5, Canada.

Tel: $\quad$ (1) 6137392230

Fax: (1) 6137392201

Email: elaine.konecny@blood.ca
Website: www.breast.cancer.ca

Contact: Dr Pascale Macgregor, Research Program Director

Established in 1993, the Canadian Breast Cancer Research Alliance (CBCRA) is Canada's primary funder of breast cancer study. As a unique partnership of groups from the public, private and non-profit sectors, CBCRA is committed to reducing the incidence of breast cancer, increasing survival and enhancing the lives of those affected by the disease.

\section{Canadian Federation of University Women Bourse Georgette Lemoyne}

Purpose: Award is for graduate study in any field at a Canadian university. The candidate must be studying in French and write the Statement of Intent essay (Section I) of the application in French

Eligibility: 1. Must be a graduate student 2. Must attend a university 3. Citizenship requirements: Canada 4. Restricted to female students 5. Must not be attending high school currently 6 . Both full-time and part-time students 7 . Restricted to residents of Alberta, British Columbia, Manitoba, New Brunswick, Newfoundland, Nova Scotia, Northwest Territories, Ontario, Prince Edward Island, Quebec, Saskatchewan, Yukon 8. Restricted to students studying in Alberta, British Columbia, Manitoba, New Brunswick, Newfoundland, Nova Scotia, Northwest Territories, Ontario, Prince Edward Island, Quebec, Saskatchewan, Yukon 9. Restricted to: Canadian

Value: C\$5,000

Country of Study: Any country

Closing Date: 1 November

No. of awards given last year: 1

Additional Information: cfuwcharitabletrust.ca/cfuwbourse-georgette-lemoyne-award-2019-2020/

For further information contact:

331 Cooper Street, Suite 502, Ottawa, ON K2P 0G5, Canada.

Tel: $\quad$ (1) 6132348252

Email: fellowships@cfuw.org

\section{Canadian Breast Cancer Research Alliance (CBCRA)}

375 University Avenue, 6th Floor, Toronto, ON M5G 2JS, Canada.

Tel: $\quad$ (1) 4165966598

Email: pmacgregor@cbcra.ca

\section{Canadian Bureau for International Education (CBIE)}

220 Laurier West, Suite 1550, Ottawa, ON K1P 5Z9, Canada.

Tel: (1) 6132374820

Email: scholarships-bourses@cbie.ca

Website: www.cbie.ca 
The Canadian Bureau for International Education (CBIE) is a national non-profit association comprising educational institutions, organizations and individuals dedicated to internal education and intercultural training. CBIE's mission is to promote the free movement of learners and trainees across national borders.

\section{Canada-Asia-Pacific Awards}

Purpose: To assist scholars in higher education institutions in Asia Pacific Region to undertake short-term research Eligibility: Open to students from the Asia-Pacific region Level of Study: Postgraduate

Type: Award

Value: C\$5,000-10,000

Frequency: Annual

Country of Study: Canada

Application Procedure: A completed application form must be submitted

Closing Date: 30 September

Funding: Government

Additional Information: scholarshippositions.blogspot. com/2010/09/canada-asia-pacific-award-capa.html

\section{For further information contact:}

Email: charles.labrecque@asiapacific.ca

\section{Canada-Brazil Awards - Joint Research Projects}

Purpose: The Canada-Brazil Awards - Joint Research Projects support exchanges of $\mathrm{PhD}$ students in the context of team based bilateral research projects. The projects must engage in collaborative research in key academic areas of bilateral cooperation leading to an eventual publication or collaborative research in line with the objectives of the Canada-Brazil Framework Agreement for Cooperation on Science, Technology and Innovation. Applicants must clearly explain the advantages of the partnership for both countries Eligibility: This competition is open to research teams from Canadian and Brazilian universities. The coordination of the project will be the responsibility of both the Canadian and Brazilian Project Leads and the teams will consist of $\mathrm{PhD}$ students from both institutions. Canadian and Brazilian Project Members: Must be citizens or permanent residents of the country of their institution; Must be doctoral students - Master's students and post-doctoral researchers will not be considered; Must be enrolled full-time at a post-secondary institution in their country of origin and paying the tuition fees required by that institution for the full duration of the exchange; Must be proficient in the language of instruction at the Canadian institution (English or French). Students already participating in an exchange program in Canada or in Brazil are not eligible

Level of Study: Research

Value: C $\$ 9,700$ for Canadian PhD students; for values for Brazilian students see: external link

Length of Study: 2 years

Country of Study: Any country

Closing Date: 3 July

Funding: Government

Contributor: Government of Canada, Foreign Affairs, Trade and Development Canada (DFATD)

Additional Information: www.educanada.ca/scholarshipsbourses/can/institutions/brazil-cbjp-brezil.aspx?lang=eng

\section{For further information contact:}

Email: admin-scholarships-bourses@cbie.ca

\section{Canada-CARICOM Faculty Leadership Program}

Purpose: To support international collaboration between Canadian post-secondary institutions and institutions in the CARICOM, through professional development opportunities for faculty and staff

Eligibility: This competition is open to research teams from Canadian and Brazilian universities. The coordination of the project will be the responsibility of both the Canadian and Brazilian Project Leads and the teams will consist of graduate project members from Canadian institutions and $\mathrm{PhD}$ project members from Brazilian institutions

Value: $\mathrm{C} \$ 2,700$ for faculty members for 2 to 3 weeks of course work or research as part of their professional development; $C \$ 2,700$ for international directors, managers or administrators for 2 to 3 weeks of course work, or for a practicum in the area of internationalization of postsecondary institutions or student mobility as part of their professional development; or $\mathrm{C} \$ 9,700$ for faculty members for 5 to 6 months of study or research at the graduate level

Country of Study: Any country

Closing Date: 25 April

Contributor: Global Affairs Canada: the Department of Foreign Affairs, Trade and Development (DFATD)

Additional Information: Further information is available on the International Scholarships Canada Application Tool Help webpages. If institutions experience difficulty filling out or submitting the form, they should send an email to adminscholarships-bourses@cbie.ca www.ub.edu.bs/wp-content/ uploads/2020/01/2020-2021-Caricom-Faculty-Leadershipin-Canada-Call.pdf

\section{For further information contact:}

Email: admin-scholarships-bourses@cbie.ca 


\section{Canada-CARICOM Leadership Scholarships Program}

Purpose: The Canada-CARICOM Leadership Scholarships are facilitated through institutional collaborations and student exchange agreements between Canadian institutions and institutions in the CARICOM

Eligibility: Canadian institutions will disburse scholarship funds to the scholarship recipient to contribute to the following costs: 1 . visa and/or study/work permit fees 2 . airfare, for the scholarship recipient only, to Canada by the most direct and economical route and return airfare upon completion of the scholarship 3. health insurance 4. living expenses, such as accommodation, utilities and food 5. ground transportation expenses, including a public transportation pass and 6 . books and supplies required for the recipient's study or research, excluding computers and other equipment.

Value: C\$,200 for college, $\mathrm{C} \$ 9,700$ for graduate students, $\mathrm{C} \$ 14,700$ for undergraduate and college

Length of Study: 4 month, 5 or 6 months, 8 months of study or research

Country of Study: Any country

Application Procedure: The Canadian institution must apply on behalf of the candidate(s) by submitting the online application form and uploading all supporting documents prior to the deadline. The following documents must be uploaded and attached to the online application form in one of the following formats: .pdf, .jpg, .doc, .docx, .txt or .gif. Each document must be smaller than $5 \mathrm{MB}$ in order for the application to upload successfully.

Closing Date: 3 March

Contributor: Canadian institutions

Additional Information: If institutions experience difficulty filling out or submitting the form, they should send an email to admin-scholarships-bourses@cbie.ca www.nationalmer itscholarships.com/canada-caricom-leadership-scholarships. html

\section{Canada-Chile Leadership Exchange Scholarship}

Purpose: The Canada-Chile Leadership Exchange Scholarship program provides students and researchers from Chile with short-term exchange opportunities for study or research, in Canada, at the college, undergraduate and graduate levels

Eligibility: 1. Must be citizens of Chile. Must be enrolled fulltime at a post-secondary institution in Chile and paying any tuition fees regulated by that institution for the full duration of the exchange. 2. People from Canadian institution can apply for this scholarship

Value: $C \$ 7,200$ for college, undergraduate or graduate students (Master)

Country of Study: Any country
Application Procedure: Selected candidates are encouraged to: ensure that they fulfill the requirements of the Canadian institution including academic requirements and language proficiency; submit their visa application as early as possible and follow the procedures of Immigration, Refugees and Citizenship Canada as outlined by the Canadian institution (generally a study permit is required for course work and a work permit is required for research); initiate the process for the transfer of credits to their home institution as soon as their Canadian courses have been identified; and contact alumni of the program through their home institution for advice and a local perspective on the scholarship experience Closing Date: 21 March

Additional Information: If institutions experience difficulty filling out or submitting the form, they should send an email to admin-scholarships-bourses@cbie.ca www.educanada.ca/ scholarships-bourses/can/institutions/ccles-bdlcc.aspx?lang= eng

\section{Canadian Prime Minister's Awards for Publishing (CPMA)}

Purpose: To increase the amount of published material related to Canada available in Japanese

Eligibility: Open to Japanese publishers who are likely to increase the knowledge and understanding of contemporary Canada

Level of Study: Postgraduate

Type: Scholarship

Frequency: Annual

Application Procedure: Further information available on the website

Closing Date: 15 November

Funding: Government

\section{For further information contact:}

Academic Relations (CPMA), Public Affairs, Embassy of Canada, 7-3-38 Akasaka, Minato-Ku, Japan.

Tel: $\quad$ (81) 354126298

Fax: (81) 354126249

Email: tokyo.lib-bib@international.gc.ca

\section{Emerging Leaders in the Americas Program (ELAP)}

Purpose: The Emerging Leaders in the Americas Program (ELAP) scholarships provide students and researchers from Latin America and the Caribbean with short-term exchange opportunities for study or research, in Canada, at the college, undergraduate and graduate levels 
Eligibility: Candidates who have obtained Canadian citizenship or who have applied for permanent residency in Canada are not eligible; candidates who have already participating in an exchange scholarship program funded by the Government of Canada are not eligible; candidates who have already enrolled in a degree or diploma program at a Canadian university or college are not eligible; and the candidates must be enrolled full-time at a post-secondary institution in an eligible country and paying any tuition fees regulated by that institution for the full duration of the exchange

Level of Study: Postgraduate

Type: Scholarship

Value: C\$7,200 for college, undergraduate or graduate students (Master)

Length of Study: 4 months to 1 academic year (master's and $\mathrm{PhD}) / 5$ to 6 months of study of research

Country of Study: Canada

Application Procedure: If institutions experience difficulty filling out or submitting the form, they should send an email to admin-scholarships-bourses@cbie.ca

Closing Date: 25 April

Contributor: Government of Canada

Additional Information: As part of the Emerging Leaders in the Americas Program, selected graduate-level recipients will be invited to participate in a study tour focused on Canadian democratic governance and civil society or other key priority areas www.educanada.ca/scholarships-bourses/can/institu tions/elap-pfla.aspx?lang=eng

\section{For further information contact:}

Email: admin-scholarships-bourses@cbie.ca

\section{International Council for Canadian Studies Graduate Student Scholarships}

Purpose: To provide access to crucial scholarly information and resources in Canada in support of a thesis/ dissertation

Eligibility: Open to students at the thesis or dissertation stage in the field of social sciences or humanities

Type: Scholarship

Value: $C \$ 3,500$

Frequency: Annual

Study Establishment: Any accredited Canadian University

Country of Study: Canada

Application Procedure: A completed application form and all supporting materials should be submitted to the Canadian Studies Associations

Closing Date: 31 December

Additional Information: www.iccs-ciec.ca/graduatestudent-scholarships.php
For further information contact:

Tel: (1) 6137897834 ext. 242

Email: csppec@iccs-ciec.ca

\section{Organization of American States (OAS) Fellowships Programs}

Purpose: To fund education of Canadian residents and nationals in other American nations

Eligibility: Open to Canadian residents and nationals

Level of Study: Doctorate, Graduate, MBA

Type: Fellowship

Value: US $\$ 30,000$ per academic year, which includes a round-trip economy-class airfare ticket; tuition fees and mandatory expenses for the academic program, a fixed monthly allowance, medical insurance, and a fixed annual book allowance

Length of Study: $1-2$ years

Frequency: Annual

Country of Study: Any country

Application Procedure: A completed application form must be submitted on time. Please refer website for more information

Closing Date: 7 March

Funding: Government

Additional Information: Please check at www.cbie-bcei.ca/ what-we-do/student-portal/scholarships/ www.educanada.ca/ scholarships-bourses/can/oas-oea.aspx?lang $=$ eng $\&$ view $=\mathrm{d}$

For further information contact:

Email: scholarships@oas.org

\section{Canadian Cancer Society Research Institute (CCSRI)}

Suite 300, 55 St. Clair Avenue W, Toronto, ON M4V 2Y7, Canada.

Tel: $\quad$ (1) 4169617223

Email:research@cancer.ca

Website: www.cancer.ca/research

The Canadian Cancer Society (CCS) is the largest non-government funder of cancer research in Canada. The CCS provides support for research and related programmes undertaken at Canadian universities, hospitals and other research institutions. 


\section{Union for International Cancer Control American Cancer Society International Fellowships for Beginning Investigators (ACSBI)}

Purpose: To provide funding for research that fosters a bi-directional flow of knowledge, experience, expertise and innovation to and from the United States of America

Eligibility: Candidates should be in the early stages of their career. Applications that are geared to the development of cancer control measures in developing central and east European countries are particularly encouraged

Level of Study: Postdoctorate, Professional development, Research

Type: Research grant

Value: Approx. US\$35,000

Length of Study: 1 year

Frequency: Annual

Country of Study: Any country

Application Procedure: Applicants must write for details or refer to the website

Closing Date: 1 October

Funding: Private

Contributor: American Cancer Society

Additional Information: Results are available in April of the following year. Further information is available on the website www.uicc.org/news/acsbi-fellowship-call-proposalsnow-open-0

\section{For further information contact:}

UICC Fellowships Department 3 rue du Conseil-General, Geneva, CH-1205, Switzerland.

Tel: $\quad$ (41) 228091811

Fax: (41) 228091810

Email: fellows@uicc.ch

\section{Union for International Cancer Control International Oncology Nursing Fellowships (IDNF)}

Purpose: The NCIC financially supports the International Union Against Cancer (UICC) which administers a number of fellowships to qualified professionals

Eligibility: English speaking nurses who are actively engaged in the management of cancer patients and who come from the developing and East European countries

Level of Study: Professional development

Type: Fellowship

Value: US $\$ 2,800$

Length of Study: 1-3 months

Frequency: Annual
Application Procedure: Applicants must request information

Closing Date: 1 November

Additional Information: Further information available on request or from the website

\section{For further information contact:}

UICC Fellowships Department, 3 Rue de Conseil-Général, Geneva, CH-1205, Switzerland.
Tel:
(41) 228091811
Fax: (41) 228091810
Email: fellows@uicc.org

\section{Canadian Crafts Council}

345 Lakeshore Road West, Oakville, ON L6K 1G3, Canada.

Tel: $\quad$ (1) 9058455357

Email:_kingfish@spectranet.ca

Contact: Ms Jan Waldorf

\section{Saidye Bronfman Award}

Purpose: To recognise excellence in the crafts. The award is made to a craftsperson judged to be an outstanding practitioner in their field, shown by their output over a working life, and their current level of achievement

Eligibility: Open to Canadian citizens, or individuals who have had landed immigrant status for at least three years. The nominee must have made a significant contribution to the development of crafts in Canada over a significant period of time, usually more than ten years

Level of Study: Postgraduate

Type: Award

Value: $\mathrm{C} \$ 25,000$

Frequency: Annual

Country of Study: Any country

Application Procedure: Nominations are made through CCC member associations across Canada. Award recipients are selected by a committee of leading Canadian craftspersons, including the current President of the Canadian Crafts Council, a past recipient of the Award, a nominee of the Bronfman Foundation, a gallery or museum director, and a member of the CCC Board. Members are selected to represent all major disciplines and geographic areas of Canada Closing Date: 15 June

Additional Information: canadacouncil.ca/funding/prizes/ saidye-bronfman-award 


\section{For further information contact:}

Tel: $\quad$ (1) 6135664414

Email: jennifer.cherniack@canadacouncil.ca

\section{Canadian Embassy (United States of America)}

501 Pennsylvania Ave. N.W., DC 20001-2114, Washington, United States of America.

Tel: $\quad$ (1) 2026821740

Email:_enqserv@dfait-maeci.gc.ca

Website: www.canadianembassy.org

\section{Canadian Embassy (United States of America) Research Grant Program}

Purpose: To assist individual scholars or a group of scholars in writing an article length manuscript of publishable quality and reporting their findings in scholarly publications

Eligibility: Open to full-time faculty members at accredited 4-year United States colleges and universities, as well as scholars at American research and policy planning institutes who undertake significant research projects concerning Canada, Canada and the United States, or Canada and North America. Recent $\mathrm{PhD}$ recipients who are citizens or permanent residents of the United States are also eligible to apply

Level of Study: Postgraduate

Type: Programme grant

Value: Up to US $\$ 15,000$; applicants whose project focuses on the priority topics listed above and who can demonstrate matching funds from others sources may request funding up to US $\$ 20,000$

Frequency: Annual

Study Establishment: An accredited 4-year college or university Country of Study: United States of America

Application Procedure: Applicants must provide 6 copies of the following in this order: the completed application form, a concise proposal of 4-8 pages which will identify all members of the research team, if a team project, and specify each member's affiliation and role in the study, identify the key issues or the main theoretical problem, describe and justify the appropriate methodology, present a general schedule of research activities, indicate clearly both the nature and scope of the projects contribution to the advancement of Canadian Studies, include a detailed budget including all other funding sources and a description of anticipated expenditures. A curriculum vitae, and the names and addresses of two scholars from whom the applicants will solicit recommendations should also be included. Application forms are available on request

Closing Date: 1 November

Funding: Government

Additional Information: The Research Grant Program promotes research in the social sciences and humanities with a view to contributing to a better knowledge and understanding of Canada and its relationship with the United States or other countries of the world

\section{For further information contact:}

Tel: $\quad$ (1) 2026827717

Email: daniel.abele@dfait-maeci.gc.ca

\section{Canadian Embassy Faculty Enrichment Program}

Purpose: To provide faculty members with the opportunity to develop or redevelop courses with substantial Canadian content that will be offered as part of their regular teaching load, or as a special offering to select audiences in continuing or distance education

Eligibility: Open to full-time, tenured or tenure track faculty members at accredited 4-year United States colleges and universities. Candidates should be able to demonstrate that they are already teaching, or will be authorized to teach, courses with substantial Canadian content (33\% or more). Team teaching applications are welcome. Applicants are ineligible to receive the same grant in 2 consecutive years or to receive two individual category Canadian Studies grants in the same grant period

Type: Programme

Value: Funding up to US\$6,000; applicants may request an additional US\$5,000 specifically to support student travel to Canada

Frequency: Annual

Country of Study: United States of America

Application Procedure: Applicants must contact the organization for an application form

Closing Date: 1 December

Additional Information: The Embassy especially encourages the use of new Internet technology to enhance existing courses, including the creation of instructional websites, interactive technologies and distance learning links to Canadian Universities grants.humanities.ufl.edu/2018/03/19/ canadian-embassy-faculty-enrichment-course-developmentprogram/

\section{For further information contact:}

Tel: $\quad$ (1) 2026827717

Email: daniel.abele@dfait-maeci.gc.ca 


\section{Canadian Embassy Graduate Student Fellowship Program}

Purpose: To assist graduate students in conducting part of their doctoral research in Canada to acquire a better knowledge and understanding of Canada or its relationship with the United States and other countries of the world

Eligibility: Open to full-time doctoral students at accredited 4-year colleges and universities in the United States or Canada whose dissertations are related in substantial part to the study of Canada, Canada and the United States or Canada and North America. Candidates must be citizens or permanent residents of the United States and should have completed all doctoral requirements except the dissertation when they apply for a grant

Level of Study: Graduate

Type: Fellowship

Value: Fellowships carrying stipends of up to US\$850 per month for up to 9 months

Length of Study: 9 months

Frequency: Annual

Study Establishment: An accredited 4-year college or university

Country of Study: Other

Application Procedure: Applicants must provide six copies of the following in the order listed: the completed application form, a concise letter of three to four pages which will explain clearly the present status of the candidate's doctoral studies, describe the candidate's study plans in Canada, list Canadian contacts such as Scholars, research institutes, academic institutions or libraries, state clearly the exact number of months for which financial support is needed, provide a complete and detailed budget, indicate what other funding sources are available, give the names and addresses of two referees, one of which must be the dissertation advisor, contain the dissertation prospectus which must identify the key issues or the main theoretical problem, justify the methodology and indicate clearly the nature of the dissertation's contribution to the advancement of Canadian Studies. An unofficial transcript of grades, a curriculum vitae and proof of United States citizenship or permanent residency must also be included. Application forms are available on request

Closing Date: October

Funding: Government

Additional Information: The Graduate Student Fellowship Program promotes research in the social sciences and humanities with a view to contributing to a better knowledge and understanding of Canada and its relationship with the United States or other countries of the world

\section{For further information contact:}

Tel: $\quad$ (1) 2026827727

Email: daniel.abele@dfait-maeci.gc.ca

\section{Outreach Grant}

Purpose: To encourage training and resource development

Eligibility: Open to all K-12 teacher who teach about Canada or Canada-United States relations

Level of Study: Professional development

Type: Grant

Value: Up to US\$14,000

Frequency: Annual

Country of Study: United States of America

Application Procedure: Contact the academic relations officer Closing Date: 30 June

Funding: Government

Contributor: Foreign Affairs Canada

For further information contact:

Email: outreach@physoc.org

\section{Canadian Federation of University Women (CFUW)}

331 Cooper Street, Suite 502, Ottawa, ON K2P 0G5, Canada.

Tel: $\quad$ (1) 6132348252 ext. 104

Email: cfuwfls@rogers.com

Website: www.cfuw.org

Contact: Betty A Dunlop, CFUW Fellowships Program Manager

Found in 1919, the Canadian Federation of University Women (CFUW) is a voluntary, non-partisan, non-profit, self-funded bilingual organization of 9,000 women university graduates. CFUW members are active in public affairs, working to raise the social, economic, and legal status of women as well as to improve education, the environment, peace, justice and human rights.

\section{Dr. A. Vibert Douglas Fellowship}

Purpose: The Fellowship is for a $\mathrm{PhD}$ thesis/project which focuses on advancing gender equality. The project must be led by women. The Fellowship is for a $\mathrm{PhD}$ thesis/project which focuses on advancing gender equality

Eligibility: If an applicant does not belong to an NFA of the GWI or to an organization that belongs to the IAW but meets the other criteria for the Fellowship they must make a US\$10 donation that will be split between those two organizations Level of Study: Postgraduate

Type: Fellowship

Value: US $\$ 8,000$ 
Frequency: Annual

Country of Study: Any country

Application Procedure: Those who are interested in this fellowship will need to pay a US\$60 application fee

Closing Date: 3 December

Funding: Private

Additional Information: For more information, visit fcfdu. fluidreview.com/ www.fcfdu.org/fellowshipsawards/dravib ertdouglasfellowship.aspx

\section{Canadian Foundation for the Study of Infant Deaths}

Suite 308, 586 Eglinton Avenue East, Toronto, ON M4P 1P2, Canada.

\section{Tel: $\quad$ (1) 4164883260}

Email:_sidsinfo@sidscanada.org

Website: www.sidscanada.org

Contact: Ravit Lasman, Executive Director

The Canadian Foundation for the Study of Infant Deaths is a federally incorporated charitable organization that was set up in 1973 to respond to the needs of families experiencing sudden and unexpected infant death. It is the only organization in Canada solely dedicated to finding the causes of Sudden Infant Death Syndrome, its effect on families and the education of the public.

\section{Cypress-Fairbanks Independent School District/ CIHR Doctoral and Postdoctoral Research Awards}

\section{For further information contact:}

The Canadian Institutes of Health Research, 440 Laurier Ave. 9th fl., Locator 4209A, Ottawa, ON K1A 0W9, Canada.

Tel: $\quad$ (1) 6139541964

Fax: (1) 6139411800

Email: srobertson@cihr.ca

\section{Canadian Institute for Advanced Legal Studies}

PO Box 43538, Leaside Post Office, 1601 Bayview Avenue, Toronto, ON M4G 4G8, Canada.

Tel: $\quad$ (1) 4164293292

Email: info@canadian-institute.com
Website: www.canadian-institute.com

Contact: Mr Randall J. Hofley, Vice-President

The Canadian Institute for Advanced Legal Studies conducts legal seminars for judges and lawyers in Cambridge, United Kingdom and Strasbourg, France.

\section{French Language Scholarship}

Purpose: For graduate studies in law toward a second cycle or third cycle diploma (the equivalent of a Master's or Doctoral degree from a Canadian university), at a European university for a program of study that is conducted principally in the French language, to a person who has, in the four years before the candidate will commence the proposed studies been awarded a bachelor's degree in law from a Canadian university

Eligibility: An applicant must be accepted into a Frenchlanguage European university for graduate studies in law in order to receive this Scholarship, although such acceptance need not be confirmed at the time of the application for the Scholarship or at the time that the Institute provides the candidate with notice that he or she has been selected to receive the Scholarship

Level of Study: Postgraduate

Type: Scholarship

Value: Full tuition fees payable by the recipient to a Frenchlanguage European university and includes an allowance to cover a portion of living expenses and reasonable travel expenses to and from the European university, subject to any other awards received by the successful candidate. The Canadian Institute for Advanced Legal Studies shall determine each year the maximum amount of the scholarship, up to an amount of US $\$ 20,000$ for the academic year, and in so doing will take into account the tuition fees as well as the anticipated living expenses and travel expenses of the successful candidate

Length of Study: 1 year

Frequency: Annual

Study Establishment: French Language European University

Country of Study: Europe, Germany

Application Procedure: Applications must include: Curriculum vitae; 1 . A personal statement indicating why the applicant wishes to undertake graduate studies in law and why the applicant is suited to undertake such studies, as well as an undertaking that the proposed program study is conducted principally in the French language. 2. A copy of transcripts for undergraduate and graduate studies, for studies in law or for a Bar Admission Course, as applicable. 3. A maximum of three letters of reference. 4. A statement of tuition fees and anticipated living and travel expenses 
Closing Date: 1 December

Funding: Trusts

Contributor: Canadian Institute for Advanced Legal Studies

Additional Information: www.canadian-institute.com/ english/index.html

\section{For further information contact:}

Canadian Institute for Advanced Legal Studies, P.O.Box 43538, Leaside Post Office, 1601 Bayview Avenue, Toronto, ON M4G 4G8, Canada.

Tel: (1) 4164293292

Fax: (1) 4164299805

\section{The Right Honorable Paul Martin Sr. Scholarship}

Purpose: To study for an LLM at the University of Cambridge

Eligibility: Open to graduates who have been awarded a law degree from a 3- or 4-year program at a faculty of law in a Canadian university in the 4 years before the candidate will commence his or her studies at the University of Cambridge (supported by The Right Honourable Paul Martin Sr. Scholarship). An applicant must be accepted into the University of Cambridge and a college of the University of Cambridge for graduate studies in law in order to receive this scholarship, although such acceptance need not be confirmed at the time of the application for the scholarship nor at the time that the Institute provides the candidate with notice that he or she has been selected to receive the scholarship

Level of Study: Postgraduate

Type: Scholarship

Value: $£ 23,000$

Length of Study: 1 year

Frequency: Annual

Study Establishment: The University of Cambridge

Country of Study: United Kingdom

Application Procedure: Applications must include curriculum vitae; a personal statement indicating why the applicant wishes to undertake graduate studies in law at the University of Cambridge and why the applicant is suited to undertake such studies; a copy of transcripts for undergraduate and graduate studies, for studies in law and for a Bar Admissions Course, as applicable; and a maximum of three letters of references

No. of awards offered: 25

Closing Date: 3 December

Funding: Private

No. of awards given last year: 2

No. of applicants last year: 25
Additional Information: The scholarship may be held with another small award as approved by the Institute. Please check at www.canadian-institute.com/english/index.html www.canadian-institute.com/english/index.html

\section{For further information contact:}

Canadian Institute for Advanced Legal Studies, P.O.Box 43538, Leaside Post Office, 1601 Bayview Avenue, Toronto, ON M4G 4G8, Canada.

Fax: (1) 4164299805

\section{Canadian Institutes of Health Research}

Canadian Institutes of Health Research; 160 Elgin Street, 9th Floor; Address Locator 4809A; Ottawa, ON K1A 0W9, Canada.

The Canadian Institutes of Health Research (CIHR) is Canada's federal funding agency for health research. Composed of 13 Institutes, we collaborate with partners and researchers to support the discoveries and innovations that improve our health and strengthen our health care system.

\section{Banting Postdoctoral Fellowships}

Eligibility: Open to Canadian citizen, permanent resident of Canada, foreign citizens

Level of Study: Postdoctorate

Type: Award

Value: $\mathrm{C} \$ 70,000$ per year (taxable)

Length of Study: 2 years

Country of Study: Canada

Closing Date: April

Additional Information: For more details, visit website ban ting.fellowships-bourses.gc.ca/en/app-dem_guide.html

\section{For further information contact:}

Email: banting@cihr-irsc.gc.ca

\section{Canadian Institutes of Health Research Gold Leaf Prizes}

Eligibility: Open to Canadian citizen, permanent resident of Canada, foreign citizens

Type: Grant

Value: $C \$ 100,000$ 
Length of Study: 2 years

Frequency: Every 2 years

Country of Study: Canada

Additional Information: For more details, please visit the Contact Centre: support@cihr-irsc.gc.ca cihr-irsc.gc.ca/e/ 27894.html

\section{For further information contact:}

Email: support@cihr-irsc.gc.ca

\section{Foundation Grant Program}

Purpose: Foundation grants are designed to support research leaders at any career stage to build and conduct programmes of health research across CIHR's mandate

Eligibility: Open to Canadian citizen, permanent resident of Canada, foreign citizens

Type: Grant

Value: Proportionate to the requirements of the research proposed and vary depending on the research field, research approach, and scope of programme activities

Length of Study: 5 to 7 years

Country of Study: Canada

Application Procedure: Please refer website www.cihr-irsc. gc.ca

Closing Date: 14 March

Additional Information: For more details, please visit the Contact Centre: support@cihr-irsc.gc.ca

cihr-irsc.gc.ca/e/49798.html

\section{For further information contact:}

Email: nbf@aabb.org

\section{Project Grant Program}

Purpose: Project grants are designed to support researchers at any career stage to build and conduct health-related research and knowledge translation projects across CIHR's mandate Eligibility: Open to Canadian citizen, permanent resident of Canada, foreign citizens

Type: Grant

Country of Study: Canada

Application Procedure: Your research proposal must include all crucial information (including tables, charts, figures and photographs) that a reviewer will need to read in order to assess your application. Reviewers are under no obligation to read other supplementary application materials that you may attach.

Closing Date: 15 May
Additional Information: For more details, please contact the Contact Centre: support@cihr-irsc.gc.ca cihr-irsc.gc.ca/e/ 49051.html

For further information contact:

Fax: (1) 6139541968

Email: support-soutien@cihr-irsc.gc.ca

\section{Vanier Canada Graduate Scholarships}

Purpose: The Vanier Canada Graduate Scholarships (Vanier CGS) was created to attract and retain world-class doctoral students and to establish Canada as a global centre of excellence in research and higher learning. The scholarships are towards a doctoral degree (or combined $\mathrm{MA} / \mathrm{PhD}$ or $\mathrm{MD} / \mathrm{PhD})$.

Eligibility: 1. be nominated by only one Canadian institution, which must have received a Vanier CGS quota 2. be pursuing your first doctoral degree (including joint undergraduate/graduate research program such as: $\mathrm{MD} / \mathrm{PhD}$, $\mathrm{DVM} / \mathrm{PhD}, \mathrm{JD} / \mathrm{PhD}$ - if it has a demonstrated and significant research component). Note that only the $\mathrm{PhD}$ portion of a combined degree is eligible for funding 3 . intend to pursue, in the summer semester or the academic year following the announcement of results, full-time doctoral (or a joint graduate program such as: $\mathrm{MD} / \mathrm{PhD}, \mathrm{DVM} / \mathrm{PhD}, \mathrm{JD} / \mathrm{PhD}$ ) studies and research at the nominating institution Note that only the $\mathrm{PhD}$ portion of a combined degree is eligible for funding 4. not have completed more than 20 months of doctoral studies as of May 1. 5. have achieved a first-class average, as determined by your institution, in each of the last two years of full-time study or equivalent. Candidates are encouraged to contact the institution for its definition of a first-class average and 6. must not hold, or have held, a doctoral-level scholarship or fellowship from CIHR, NSERC or SSHRC to undertake or complete a doctoral degree.

Level of Study: Doctorate

Type: Scholarship

Value: $C \$ 50,000$ per year

Length of Study: 3 years

Frequency: Annual

Country of Study: Canada

No. of awards offered: 166

Closing Date: 20 November

Additional Information: vanier.gc.ca/en/nomination process-processus_de_mise_en_candidature.html

\section{For further information contact:}

Email: vanier@cihr-irsc.gc.ca 


\section{Canadian Library Association (CLA)}

1150 Morrison Drive, Suite 400, Ottawa, ON K2H 8S9, Canada.

Tel: $\quad$ (1) 6132329625

Email: info@cla.ca

Website: www.cla.ca

Contact: Valoree McKay, Executive Director

The Canadian Library Association works to maintain a tradition of commitment to excellence in library education and to advance continuing research in the field of library and information science.

\section{Canadian Library Association Library Research and Development Grants}

Purpose: To support members of the Canadian Library Association for theoretical and applied research in the related fields. To encourage and support research undertaken by practitionares in the field of library and information services. To promote research in the field of library and information services by and/or about Canadians

Eligibility: Open to personal members of the Canadian Library Association

Level of Study: Postgraduate

Type: Grant

Value: $C \$ 1,000$

Frequency: Annual

Country of Study: Canada

Application Procedure: Applicants must submit grant applications via emails and MS word document in either French or English containing contact details, description of the research project, duration of the project, detailed assessment of costs and statement of other grants/awards received. Proposals should be submitted via email

Closing Date: February

Additional Information: Please check at www.cla.ca/AM/ Template.cfm?Section $=$ Grants\&amp;Template $=/ \mathrm{CM} / \mathrm{HTML}$ Display.cfm\&amp;ContentID $=12526$ cla.ca/cla-at-work/clalibrary-research-and-development-grants/

\section{For further information contact:}

Tel: (1) 6132329625 ext 322

Fax: (1) 6135639895

\section{Canadian National Institute for the Blind (CNIB)}

1929 Bayview Avenue, East York, Toronto, ON M4G 0A1, Canada.

Tel: $\quad$ (1) 8005632642 , (1) 4164862500

Email: info@cnib.ca

Website: www.cnib.ca

Contact: Mr John M Rafferty, President and CEO

CNIB is a nationwide, community-based, registered charity committed to public education, research and the vision health of all Canadians. CNIB provides the services and support necessary to enjoy a good quality of life while living with vision loss. Founded in 1918, CNIB reaches out to communities across the country, offering access to rehabilitation training, innovative consumer products and peer support programs as well as one of the world's largest libraries for people with a print disability. CNIB supports research to advance knowledge in the field of vision health. Our research program funds projects that focus on ways to cure, treat and prevent eye disease, and improve the quality of life for people with vision loss.

\section{Canadian National Institute for the Blind Baker Applied Research Fund}

Purpose: To promote non-medical applied research that will enhance the life of the blind or visually impaired

Eligibility: Open to residents of Canada enrolled in graduate study in Canada, and includes a co-applicant who is either a supervisor or mentor with an academic appointment in Canada, or a supervisory position at a healthcare facility. Refer to the website for complete details

Level of Study: Research

Value: Up to $C \$ 40,000$ plus travel and publications costs up to $\mathrm{C} \$ 2,000$

Length of Study: One year

Frequency: Annual

Country of Study: Canada

Funding: Private

Additional Information: univrsapp.usask.ca/converis/ publicweb/cfFund $/ 5654$ ? share $=$ false $\&$ cntpers $=$ false \& reqst fulltxt $=$ false \&reports $=$ false $\&$ lang $=1$ 
For further information contact:

Tel: $\quad$ (1) 4164862500 ext. 7622

Fax: (1) 4164807059

Email: shampa.bose@cnib.ca

\section{Canadian National Institute for the Blind Baker Fellowship Fund}

Purpose: CNIB's Baker Fellowships are awarded annually for post-graduate training in ophthalmic subspecialties

Eligibility: Open to Canadians for research or study in Canada, or abroad if returning to practice in Canada, with priority given to university teaching

Level of Study: Postgraduate, Professional development, Research

Value: Up to $C \$ 40,000$

Length of Study: $1-2$ years

Frequency: Annual

Country of Study: Any country

Funding: Private

For further information contact:

Tel: $\quad$ (1) 4164862500 ext. 7622

Fax: (1) 4164807059

Email: shampa.bose@cnib.ca

\section{Canadian National Institute for the Blind Baker New Researcher Fund}

Purpose: To provide one-year grants to encourage new investigations that may lead to the prevention of vision loss. It is intended to benefit new investigators (within 5 years after an academic faculty appointment) by giving them experience and results which can assist them in further grant applications and pilot investigations

Eligibility: Applicants must be residents of Canada and research must be conducted primarily in Canada

Level of Study: Postdoctorate, Professional development, Research

Value: Up to $C \$ 35,000$

Length of Study: 1 year

Frequency: Annual

Country of Study: Canada

Funding: Private

For further information contact:

Tel: $\quad$ (1) 4164862500 ext. 7622

Fax: (1) 4164807059

Email: shampa.bose@cnib.ca

\section{Canadian National Institute for the Blind Winston} Gordon Award

Purpose: The award is presented to an individual or group who has made significant technological advances benefiting people with vision loss

Eligibility: The significant advances in, or application of, technology must have occurred within 10 years of nomination. The device or application must have a documented benefit to people who are blind or visually impaired. The award may be presented to an individual, group, or organization, including corporations and academic institutions

Type: Award

Value: The award consists of a cash prize of up to $\mathrm{C} \$ 10,000$ Country of Study: Any country

Application Procedure: To submit a nomination, please write a letter to the Winston Gordon Committee nominating the individual or group for its products or services, and explaining how the nominee meets or surpasses the eligibility criteria and matches the goals of the award

Closing Date: 16 January

Funding: Private

Additional Information: cnib.ca/en/about-us/awards/ winston-gordon-award-excellence-accessible-technology? region $=$ gta

\section{For further information contact:}

Winston Gordon Award Committee, CNIB, 1929 Bayview Avenue, East York, ON M4G 3E8, Canada.

Fax: (1) 4164807000

Email: shampa.bose@cnib.ca

\section{Gretzky Scholarship Foundation for the Blind Youth of Canada}

Purpose: To provide scholarships to eligible blind and visually impaired students planning to study at the post-secondary level

Eligibility: All applicants must be blind or visually impaired, a graduate from secondary school entering their first year of post-secondary education, and a Canadian citizen. Candidates must be blind or living with vision loss. A secondary school graduate entering their first year of post-secondary education. A Canadian citizen or have held landed immigrant status for one year prior to date of application. Academic excellence, service to the community, financial need, superior leadership 
Type: Scholarship

Value: $C \$ 3,000-5,000$ each

Frequency: Annual

Country of Study: Canada

Application Procedure: All documents requested in the application form must be included with your application. Please send application and documents to Kim Kohler

Closing Date: 31 May

Funding: Private

No. of awards given last year: 23

For further information contact:

955256 Canning Rd, Paris, ON N3L 3E2, Canada

Tel: (33) 5194588665

Fax: (33) 5194588609

Email: Kim.Kohler@cnib.ca

\section{Ross Purse Doctoral Fellowship}

Purpose: To encourage and support theoretical and practical research and studies at the postgraduate or doctoral level in the field of vision loss in Canada

Eligibility: Applications will be considered from persons studying at a Canadian University or college, or at a foreign University, where a commitment to work in the field of vision loss in Canada for at least 2 years can be demonstrated

Level of Study: Doctorate, Postgraduate

Type: Fellowship

Value: Up to C $\$ 12,500$ to be paid in three equal installments Length of Study: 2 years

Frequency: Annual

Country of Study: Any country

Application Procedure: Please send completed applications to Research Coordinator

No. of awards offered: 1

Closing Date: 30 June

Funding: Private

Additional Information: www.cnib.ca/en/about-us/awards/ ross-c-purse-doctoral-fellowship?region $=$ gta

\section{For further information contact:}

CNIB, 1929 Bayview Avenue, East York, ON M4G 3E8, Canada.

Tel: $\quad$ (1) 4164862500 ext. 7622

Fax: (1) 4164807000

Email: cheryl-ann.ali@cnib.ca

\section{The E. (Ben) \& Mary Hochhausen Access} Technology Research Award

Purpose: To encourage research in the field of access technology for people living with vision loss

Eligibility: Applications are accepted from any country in the world

Level of Study: Research

Type: Research award

Value: Up to $C \$ 10,000$

Country of Study: International

Application Procedure: Please check at www.cnib.ca/en/ research/funding/hochhausen/

Closing Date: 30 September

Funding: Private

No. of awards given last year: 1

Additional Information: www.cnib.ca/en/about-us/awards/ ross-c-purse-doctoral-fellowship?region $=$ gta

For further information contact:

Email: shampa.bose@cnib.ca

\section{Canadian Political Science Association}

1 Stewart Street, Suite 205, University of Ottawa, Ottawa, ON K1N 6H7, Canada.

Tel:

(1) 6135621202

Email:_pip@csse.ca

Contact: Grants Management Officer

The Canadian Political Science Association was founded in 1913 with the aim of encouraging and developing political science and its relationship with other disciplines. To this end the Association holds conferences, meetings and exhibitions, gives grants, scholarships and fellowships and publishes journals, newspapers, books and monographs relating to political science.

\section{Canadian Parliamentary Internship Programme}

Purpose: To give university graduates an opportunity to supplement their theoretical knowledge of Parliament with practical experience of the day to day work of the Members of Parliament and to provide back bench Members with highly qualified assistants

Eligibility: Open to Canadian university graduates 
Level of Study: Postgraduate

Type: Scholarship

Value: An estimated stipend of $\mathrm{C} \$ 16,500$, plus travel subsidies

Length of Study: 10 months

Frequency: Annual, if funds are available

Study Establishment: The Canadian Parliament

Country of Study: Canada

Application Procedure: Applicants must submit the original and four copies of the completed application form, transcripts, letters of reference (two academic, one employer), and US $\$ 10$ administrative fee cheque

Closing Date: January

Funding: Private

Contributor: The Social Sciences and Humanities Research council of Canada, Bank of Montreal, Canadian Airlines International, Canadian Bankers Association, Canadian Cable Television Association, The Canadian Life and Health Association, The Co-operators

Additional Information: Interns will be assigned specific responsibilities with Members of the House of Commons and will be required to attend seminars and prepare a paper analysing an aspect of parliamentary government in Canada

\section{For further information contact:}

The Parliamentary Internship Programme, Room 1200, La Promenade Building, 151 Sparks Street, House of Commons, Ottawa, ON K1P 5E3, Canada.

Tel: $\quad$ (44) 6139950764

Fax: (44) 6139955357

Email: cartwj@parl.gc.ca

\section{Ontario Legislature Internship Programme}

Purpose: To provide university graduates with the opportunity to supplement their theoretical knowledge of the Legislature and its processes with practical experience of the day to day work of the members, and to provide back bench members with highly qualified assistants

Eligibility: Open to Canadian citizens only

Level of Study: Postgraduate

Type: Internship

Value: C\$16,000

Length of Study: 10 months

Frequency: Dependent on funds available

Country of Study: Canada

Application Procedure: Applicants must complete an application form, available on request from the Program Officer

No. of awards offered: 97

Closing Date: January
Funding: Government, Commercial, Private

No. of awards given last year: 8

No. of applicants last year: 97

\section{For further information contact:}

Department of Political Science, University of Waterloo, 200

University Ave W, Waterloo, ON N2L 3G1, Canada.

Tel: $\quad$ (1) 5198884567 ext. 5682

Fax: (1) 5197465622

Email: olip@watarts.uwaterloo.ca

\section{Canadian Society for Chemical Technology}

Chemical Institute of Canada, 222 Queen Street, Suite 400, Ottawa, ON K1P 5V9, Canada.

Tel:

Email: awards@cheminst.ca

Website: www.cheminst.ca/about/cic/csct

Contact: Gale Thirlwall, Awards Manager

The Canadian Society for Chemical Technology is the national technical association of chemical and biochemical technicians and technologists with members across Canada who work in industry, government or academia. The purpose of the Society is the advancement of chemical technology, the maintenance and improvement of practitioners and educators and the continual evaluation of chemical technology in Canada. The Society hopes to maintain a dialogue with educators, government and industry, to assist in the technology content of the education process of technologists, to attract qualified people into the professions and the Society, to develop and maintain high standards and enhance the usefulness of chemical technology to both the industry and the public.

\section{Canadian National Committee/IUPAC Travel Awards}

Purpose: The purpose of these Awards is to help young Canadian scientists and engineers within 10 years of having gained their $\mathrm{PhD}$ who are currently working at a Canadian institution, present a paper at an IUPAC-sponsored conference outside of Canada.

Eligibility: A list of IUPAC-sponsored conferences for 2020 can be found on the IUPAC web-site (www.iupac.org/) and 
also in Chemistry International, the IUPAC magazine. Awards are made to attend the conference identified in the application, and no changes are allowed without written permission from the Chair

Level of Study: Postdoctorate

Value: Up to US $\$ 2,500$, paid in arrears after travel-expense receipts and a 150-word report on the conference have been received by the Secretary

Country of Study: Any country

Application Procedure: 1. a short Curriculum Vitae, 2. two Letters of Reference, including one from someone not at the applicant's university, research institution or company. 3. a cover letter outlining the name and location of the conference, a copy or link to the conference circular and the reasons why this particular conference fits your research goals.

No. of awards offered: 4

Closing Date: 16 October

Funding: Private

Contributor: Gendron Fund and CNC/IUPAC company associates

No. of awards given last year: 4

Additional Information: www.cnc-iupac.ca/awards_e.html

\section{For further information contact:}

Steacie Institute for Molecular Sciences, NRC 100 Sussex Dr, Ottawa, ON K1A 0R6, Canada.

Tel: $\quad$ (1) 6139908326

Email: Homin.Shin@nrc-cnrc.gc.ca

\section{Canadian Society for Chemistry (CSC)}

222 Queen Street, Suite 400, Ottawa, ON KIP 5V9, Canada.

Tel: $\quad$ (1) 6132326252 ext 223

Email: awards@cheminst.ca

Website: www.cheminst.ca/about/cic/csc

Contact: Gale Thirlwall, Awards Manager

The Canadian Society for Chemistry (CSC), one of three constituent societies of The Chemical Institute of Canada, is the national scientific and educational society of chemists. The purpose of the CSC is to promote the practice and application of chemistry in Canada.

\section{Award for Research Excellence in Materials Chemistry}

Purpose: To recognize outstanding contribution to materials chemistry while working in Canada
Eligibility: Candidates must be within 15 years of their first independent appointment

Level of Study: Research

Type: Fellowship

Value: Up to US $\$ 1,000$ travel costs for award tour, framed scroll

Frequency: Annual

Application Procedure: Please check website for details

Closing Date: 2 July

Funding: Private

Additional Information: Please check at www.cheminst.ca/ awards/csc-awards www.cheminst.ca/wp-content/uploads/ 2019/04/Award20for20Research20Excellence20in20Mater ials20Chemistry20TofR.pdf

\section{Canadian Space Agency}

John H. Chapman 6767 Route de l'Aéroport Saint-Hubert, Quebec J3Y 8Y9, Canada.

Tel: $\quad$ (1) 4509264800

Email:_dave.kendall@space.gc.ca

Website: www.asc-csa.gc.ca

Contact: David Kendall, Director General, Space Science

The Canadian Space Agency (CSA) was established in 1989 by the Canadian Space Agency Act. The agency operates like a government department

\section{Canadian Space Agency Supplements Postgraduate Scholarships}

Purpose: To foster advanced studies in space science by offering a supplement to the regular National Science and Engineering Research Council (NSERC) postgraduate scholarships

Eligibility: Open to graduate and permanent resident and citizen of Canada engaged in Masters or Doctoral studies in the natural sciences or engineering, or intend to pursue such studies in the following year, is successful in obtaining a NSERC postgraduate scholarship (PGS) or a Canada graduate scholarships (CGS-Master's)

Level of Study: Postgraduate

Type: Scholarship

Value: C\$7,500 per year for one year for masters students and up to two years for doctoral students

Length of Study: 2 years

Frequency: Annual

Country of Study: Canada

Application Procedure: Candidates should apply to the NSERC postgraduate scholarship or Canada graduate 
scholarship programs by completing Form 200. After reviewing the forms, notification of award will be sent to the selected applicants

Closing Date: 1 May

Funding: Government

Contributor: National Science and Engineering Research Council

Additional Information: A candidate who is in receipt of a scholarship from federal sources other than NSERC will not be eligible for this supplement. Please check at www.asc-csa. gc.ca/eng/resources/gc/research.asp\#recipients-2

\section{For further information contact:}

Email: sc-gc.centre.expertise@asc-csa.gc.ca

\section{Cancer Council N.S.W}

153 Dowling Street, Woolloomooloo, NSW 2011, Australia.

Tel: $\quad$ (61) 293341900

Email: rong@nswcc.org.au

Website: www.cancercouncil.com.au

The Cancer Council NSW is one of the leading cancer charity organizations in New South Wales. Its mission is to defeat cancer and is working to build a cancer-smart community. In building a cancer-smart community, the Council undertakes high-quality research and is an advocate on cancer issues, providing information and services to the public and raising funds for cancer programmes

\section{The Cancer Council NSW Research Project Grants}

Purpose: To provide flexible support for cancer researchers Eligibility: Open to researchers working in NSW institutions Level of Study: Unrestricted

Type: Project grant

Value: up to AU $\$ 450,000$

Length of Study: Up to 3 years

Frequency: Annual

Study Establishment: An approved institution in New South Wales

Country of Study: Australia

Application Procedure: Applicants must complete an application form, available on request or from the website. Applications are submitted through the researcher's institution to NHMRC. Applicants must also complete a supplementary question form and a consumer review form

No. of awards offered: 106
Closing Date: 11 March

Funding: Private

Contributor: Community fund-raising

No. of applicants last year: 106

Additional Information: Further information is available from either the NHMRC Liaison Officer (National Cancer Research Grants Secretariat) or from Cancer Council NSW. Please check at www.cancercouncil.com.au/1221/ research/research-funding-and-governance/funding-opport unities/new-grants/ www.cancercouncil.com.au/research/forresearchers/cancer-research-grants/project-grant-applications/

\section{For further information contact:}

NHMRC, GPO Box 9848, Canberra ACT 2601, Australia.

Tel: $\quad$ (61) 396355028

Email: CancerCouncilGrants@cancervic.org.au

\section{Cancer Council South Australia}

202 Greenhill Road, Eastwood, SA 5063, Australia.

Tel: $\quad$ (61) 82914111

Email: cc@cancersa.org.au

Website: www.cancersa.org.au

The Cancer Council South Australia is a community-based charity independent of government control that has developed since 1928 with the support of South Australians. The Foundation's mission is to pursue the eradication of cancer through research and education on the prevention and early detection of cancer, thus enhancing the quality of life for people living with cancer.

\section{PhD Scholarships}

Purpose: To support cancer researchers in South Australia through the provision of research and senior research fellowships

Eligibility: Applicant must be a student judged to be the best applicant from University of Adelaide, Flinders University or University of South Australia, who is commencing PhD studies. The applicant must not be currently enroled in a $\mathrm{PhD}$, must be eligible for the Research Training Scheme and must not have been previously enroled for a Research Degree. Students are eligible to apply for the scholarship if they are enroled in the Faculty or Division of Health Sciences at their institution and if their $\mathrm{PhD}$ topic is in an area of cancer research

Level of Study: Postgraduate 
Type: Scholarship

Value: Equivalent to the value of the stipend for an APA award

Length of Study: 3 years

Frequency: Annual

Country of Study: Australia

Application Procedure: Applicants must contact the relevant Scholarships Offices of The University of Adelaide, University of South Australia and Flinders University for further information and closing dates

\section{For further information contact:}

Tel: $\quad$ (61) 882914297

Email: npolglase@cancersa.org.au

\section{Cancer Immunotherapy}

\section{National Cancer Institute Immunotherapy Fellowship}

Purpose: This program allows the fellow to have exposure to multiple clinical immunotherapeutic approaches and key opinion leaders in the field of clinical immunotherapy. It helps to work with internationally recognized experts in immunotherapy

Eligibility: 1. Able to relocate to Bethesda, MD, for the duration of the fellowship. 2. Trained in Medical Oncology, Hematology, Pediatric Oncology, Radiation Oncology, or Surgical Oncology. 3. Interest in learning about immunotherapy. 4. Preference is given to those with an academic interest. 5. Open to United States and Non-United States trained physicians (the latter requires ECFMG certification)

Level of Study: Research

Type: Fellowships

Value: It is based on applicable laws, regulations, and policies Frequency: Annual

Country of Study: Any country

Application Procedure: For further information, refer the below web link. www.sitcancer.org/funding/fellowships/ 2019/nci-immunotherapy-fellowship

Closing Date: 17 December

Funding: Private

Additional Information: www.sitcancer.org/funding/fellow ships/2019/nci-immunotherapy-fellowship

\section{For further information contact:}

555 East Wells Street, Suite 1100, Milwaukee, WI 532022823, United States of America.

Email: development@sitcancer.org

\section{Society for Immunotherapy of Cancer - Amgen Cancer Immunotherapy in Hematologic Malignancies Fellowship Award}

Purpose: This cancer immunotherapy fellowship award aims to provide support for an individual who has a vested interest in furthering the research and translation of immunotherapeutic approaches for treating patients with hematologic malignancies Eligibility: Candidature must follow the below eligibility to obtain the fellowship award. 1. Current SITC member. 2. Hold an MD or combined $\mathrm{MD} / \mathrm{PhD}$ degree. 3. Currently hold a position at a leading academic cancer center as a postdoctoral fellow, resident, research scientist or comparable position. 4. Be within postdoctoral or postgraduate training, or no more than four years from completing such training. 5. Commit $75 \%$ of workday to research supported by the fellowship Level of Study: Professional development

Type: Award/Grant

Value: US\$100,000

Frequency: Annual

Country of Study: Any country

Application Procedure: The successful applicant will obtain the following benefits along with the award amount, omce they are eligible for the fellowship award. 1. Complimentary registration and travel for SITC's 34th Annual Meeting. 2. Recognition during the Award Ceremony at SITC's 34th Annual Meeting

Closing Date: 1 March

Funding: Private

Additional Information: www.sitcancer.org/funding/fellow ships/2019/amgen-immunotherapy-hematologic-malignancies

\section{For further information contact:}

Tel: $\quad$ (1) 4142712456

Email: development@sitcancer.org

\section{Cancer Prevention and Research Institute of Texas - CPRIT}

1701 North Congress Avenue, Austin, Suite 6-127, TX 78701, United States of America.

Tel:

(1) 5124633190

Email: cprit@cprit.texas.gov

Website: www.cprit.state.tx.us/

Texas voters overwhelmingly approved a constitutional amendment in 2007 establishing the Cancer Prevention and Research Institute of Texas (CPRIT) and authorizing the state 
to issue US $\$ 3$ billion in bonds to fund groundbreaking cancer research and prevention programs and services in Texas. CPRIT's goal is to expedite innovation in cancer research and product development, and to enhance access to evidence-based prevention programs throughout the state. Under the guidance of its governing body, the Oversight Committee, CPRIT accepts applications and awards grants for a wide variety of cancer-related research and for the delivery of cancer prevention programs and services by public and private entities located in Texas. All CPRIT-funded research will be conducted in state by Texas-based scientists and reflect CPRIT's mission to attract and expand the state's research capabilities and create high quality new jobs in Texas.

\section{Individual Investigator Research Awards (IIRA)}

Purpose: Supports applications for innovative research projects addressing critically important questions that will significantly advance knowledge of the causes, prevention, and/or treatment of cancer. Areas of interest include laboratory research, translational studies, and/or clinical investigations. Competitive renewal applications accepted.

Eligibility: The applicant must be a Texas-based institution of higher education or a component of a university system with appropriately accredited degree-granting training programs (if support is requested for training leading to a degree). 1. The Principal Investigator (PI) must have a doctoral degree, including $\mathrm{MD}, \mathrm{PhD}$, DDS, DMD, DrPH, DO, DVM, or equivalent, and must be a full-time resident of Texas during the time the research that is the subject of the grant is conducted. 2. An institution may submit only 1 new or renewal application under this RFA during this funding cycle. An exception will be made for institutions submitting applications for cancer prevention training; in this case, institutions may submit 1 prevention training program application and 1 additional application in another aspect of cancer research (new or renewal). 3. For the purposes of this RFA, an institution is defined as that component of a university system that has its own president. 4 . There must be only 1 PI, but Co-PIs may direct individual components of the overall program described in the application. 5. An institution may apply for as many components of the training program as are appropriate for the institution. 6. An applicant is eligible to receive a grant award only if the applicant certifies that the applicant institution or organization, including the PI, any senior member or key personnel listed on the grant application, or any officer or director of the grant applicant's institution or organization (or any person related to 1 or more of these individuals within the second degree of consanguinity or affinity), has not made and will not make a contribution to CPRIT or to any foundation specifically created to benefit
CPRIT. 7. An applicant is not eligible to receive a CPRIT grant award if the applicant PI, any senior member or key personnel listed on the grant application, or any officer or director of the grant applicant's organization or institution is related to a CPRIT Oversight Committee member. CPRIT RFA R-21.1-RTA Research Training Awards Page 10 of $24(\operatorname{Rev} 1 / 31 / 20) 8$. The applicant must report whether the applicant institution or organization, the PI, or other individuals who contribute to the execution of the proposed project in a substantive, measurable way, whether or not those individuals are slated to receive salary or compensation under the grant award, are currently ineligible to receive federal grant funds or have had a grant terminated for cause within 5 years prior to the submission date of the grant application. 9. CPRIT grants will be awarded by contract to successful applicants. Certain contractual requirements are mandated by Texas law or by administrative rules. Although applicants need not demonstrate the ability to comply with these contractual requirements at the time the application is submitted, applicants should make themselves aware of these standards before submitting a grant application. Significant issues addressed by the CPRIT contract are listed in section 10 and section 11. All statutory provisions and relevant administrative rules can be found at www.cprit.state.tx.us.

Level of Study: Masters

Type: Scholarships

Value: Award: Up to US $\$ 300,000$ per year in total costs. Exceptions permitted if extremely well justified;

Length of Study: 3 years

Country of Study: US

Application Procedure: Each application must be accompanied by a letter of institutional support from the president or provost indicating support and commitment to the training program. The letter could include, but is not limited to, information about laboratory space, shared laboratory facilities and equipment, funds for curriculum development, support for additional trainees in the program, and initiatives to support recruitment of underrepresented minorities. A maximum of 3 pages may be provided. Applications that are missing 1 or more of these components, exceed the specified page, word, or budget limits, or that do not meet the eligibility requirements listed above will be administratively rejected without review. 8.3. Formatting Instructions Formatting guidelines for all submitted CPRIT applications are as follows: 1. Language: English. 2. Document Format: PDF only. 3. Font Type/Size: Arial (11 point), Calibri (11 point), or Times New Roman (12 point). 4. Line Spacing: Single. 5. Page Size: 8.5 x 11 inches. 6. Margins: 0.75 inch, all directions. 7. Color and High-Resolution Images: Images, graphs, figures, and other illustrations must be submitted as part of the appropriate submitted document. Applicants should include text to explain illustrations that may be difficult to interpret when printed in black and white. CPRIT RFA 
R-21.1-RTA Research Training Awards Page 17 of 24 (Rev 1/31/20) 8. Scanning Resolution: Images and figures must be of lowest reasonable resolution that permits clarity and readability. Unnecessarily large files will NOT be accepted, especially those that include only text. 9. References: Applicants should use a citation style that includes the full name of the article and that lists at least the first 3 authors. Official journal abbreviations may be used. An example is included below; however, other citation styles meeting these parameters are also acceptable as long as the journal information is stated. Include URLs of publications referenced in the application. Smith, P.T., Doe, J., White, J.M., et al (2006). Elaborating on a novel mechanism for cancer progression. Journal of Cancer Research, 135: 45-67. 10. Internet URLs: Applicants are encouraged to provide the URLs of publications referenced in the application; however, applicants should not include URLs directing reviewers to websites containing additional information about the proposed research. 11. Headers and Footers: These should not be used unless they are part of a provided template. Page numbers may be included in the footer (see following point). 12. Page Numbering: Pages should be numbered at the bottom right corner of each page. 13. All attachments that require signatures must be filled out, printed, signed, scanned, and then uploaded in PDF format

Closing Date: 3 June

Additional Information: cpritgrants.org/

\section{Individual Investigator Research Awards for Cancer in Children and Adolescents (IIRACCA)}

Purpose: Supports applications for innovative research projects addressing questions that will advance knowledge of the causes, prevention, progression, detection, or treatment of cancer in children and adolescents. Laboratory, clinical, or population-based studies are all acceptable. CPRIT expects the outcome of the research to reduce the incidence, morbidity, or mortality from cancer in children and/or adolescents in the near or long term. Competitive renewal applications accepted.

Eligibility: The applicant must be a Texas-based institution of higher education or a component of a university system with appropriately accredited degree-granting training programs (if support is requested for training leading to a degree). 1. The Principal Investigator (PI) must have a doctoral degree, including $\mathrm{MD}, \mathrm{PhD}$, DDS, DMD, DrPH, DO, DVM, or equivalent, and must be a full-time resident of Texas during the time the research that is the subject of the grant is conducted. 2. An institution may submit only 1 new or renewal application under this RFA during this funding cycle. An exception will be made for institutions submitting applications for cancer prevention training; in this case, institutions may submit 1 prevention training program application and 1 additional application in another aspect of cancer research (new or renewal). 3. For the purposes of this RFA, an institution is defined as that component of a university system that has its own president. 4 . There must be only $1 \mathrm{PI}$, but Co-PIs may direct individual components of the overall program described in the application. 5. An institution may apply for as many components of the training program as are appropriate for the institution. 6. An applicant is eligible to receive a grant award only if the applicant certifies that the applicant institution or organization, including the PI, any senior member or key personnel listed on the grant application, or any officer or director of the grant applicant's institution or organization (or any person related to 1 or more of these individuals within the second degree of consanguinity or affinity), has not made and will not make a contribution to CPRIT or to any foundation specifically created to benefit CPRIT. 7. An applicant is not eligible to receive a CPRIT grant award if the applicant PI, any senior member or key personnel listed on the grant application, or any officer or director of the grant applicant's organization or institution is related to a CPRIT Oversight Committee member. CPRIT RFA R-21.1-RTA Research Training Awards Page 10 of $24(\operatorname{Rev} 1 / 31 / 20) 8$. The applicant must report whether the applicant institution or organization, the PI, or other individuals who contribute to the execution of the proposed project in a substantive, measurable way, whether or not those individuals are slated to receive salary or compensation under the grant award, are currently ineligible to receive federal grant funds or have had a grant terminated for cause within 5 years prior to the submission date of the grant application. 9. CPRIT grants will be awarded by contract to successful applicants. Certain contractual requirements are mandated by Texas law or by administrative rules. Although applicants need not demonstrate the ability to comply with these contractual requirements at the time the application is submitted, applicants should make themselves aware of these standards before submitting a grant application. Significant issues addressed by the CPRIT contract are listed in section 10 and section 11 . All statutory provisions and relevant administrative rules can be found at www.cprit.state.tx.us.

Level of Study: Masters

Type: Scholarships

Value: Award: Up to US $\$ 300,000$ per year in total costs. Applicants that plan on conducting a clinical trial as part of the project may request up to US $\$ 500,000$ in total costs. Exceptions permitted if extremely well justified;

Length of Study: 4 years

Country of Study: US

Application Procedure: Each application must be accompanied by a letter of institutional support from the president or provost indicating support and commitment to the training program. The letter could include, but is not limited to, information about laboratory space, shared laboratory 
facilities and equipment, funds for curriculum development, support for additional trainees in the program, and initiatives to support recruitment of underrepresented minorities. A maximum of 3 pages may be provided. Applications that are missing 1 or more of these components, exceed the specified page, word, or budget limits, or that do not meet the eligibility requirements listed above will be administratively rejected without review. 8.3. Formatting Instructions Formatting guidelines for all submitted CPRIT applications are as follows: 1. Language: English. 2. Document Format: PDF only. 3. Font Type/Size: Arial (11 point), Calibri (11 point), or Times New Roman (12 point). 4. Line Spacing: Single. 5. Page Size: 8.5 x 11 inches. 6. Margins: 0.75 inch, all directions. 7. Color and High-Resolution Images: Images, graphs, figures, and other illustrations must be submitted as part of the appropriate submitted document. Applicants should include text to explain illustrations that may be difficult to interpret when printed in black and white. CPRIT RFA R-21.1-RTA Research Training Awards Page 17 of 24 (Rev $1 / 31 / 20) 8$. Scanning Resolution: Images and figures must be of lowest reasonable resolution that permits clarity and readability. Unnecessarily large files will NOT be accepted, especially those that include only text. 9. References: Applicants should use a citation style that includes the full name of the article and that lists at least the first 3 authors. Official journal abbreviations may be used. An example is included below; however, other citation styles meeting these parameters are also acceptable as long as the journal information is stated. Include URLs of publications referenced in the application. Smith, P.T., Doe, J., White, J.M., et al (2006). Elaborating on a novel mechanism for cancer progression. Journal of Cancer Research, 135: 45-67. 10. Internet URLs: Applicants are encouraged to provide the URLs of publications referenced in the application; however, applicants should not include URLs directing reviewers to websites containing additional information about the proposed research. 11. Headers and Footers: These should not be used unless they are part of a provided template. Page numbers may be included in the footer (see following point). 12. Page Numbering: Pages should be numbered at the bottom right corner of each page. 13. All attachments that require signatures must be filled out, printed, signed, scanned, and then uploaded in PDF format

Closing Date: 3 June

Additional Information: cpritgrants.org/

\section{Individual Investigator Research Awards for Clinical Translation (IIRACT)}

Purpose: Supports applications which propose innovative clinical studies that are hypothesis driven and involve patients enrolled prospectively on a clinical trial or involve analyses of biospecimens from patients enrolled on a completed trial for which the outcomes are known. Areas of interest include clinical studies of new or repurposed drugs, hormonal therapies, immune therapies, surgery, radiation therapy, stem cell transplantation, combinations of interventions, or therapeutic devices.

Eligibility: The applicant must be a Texas-based institution of higher education or a component of a university system with appropriately accredited degree-granting training programs (if support is requested for training leading to a degree). 1. The Principal Investigator (PI) must have a doctoral degree, including $\mathrm{MD}, \mathrm{PhD}, \mathrm{DDS}$, DMD, $\mathrm{DrPH}, \mathrm{DO}, \mathrm{DVM}$, or equivalent, and must be a full-time resident of Texas during the time the research that is the subject of the grant is conducted. 2. An institution may submit only 1 new or renewal application under this RFA during this funding cycle. An exception will be made for institutions submitting applications for cancer prevention training; in this case, institutions may submit 1 prevention training program application and 1 additional application in another aspect of cancer research (new or renewal). 3. For the purposes of this RFA, an institution is defined as that component of a university system that has its own president. 4. There must be only 1 PI, but Co-PIs may direct individual components of the overall program described in the application. 5. An institution may apply for as many components of the training program as are appropriate for the institution. 6. An applicant is eligible to receive a grant award only if the applicant certifies that the applicant institution or organization, including the PI, any senior member or key personnel listed on the grant application, or any officer or director of the grant applicant's institution or organization (or any person related to 1 or more of these individuals within the second degree of consanguinity or affinity), has not made and will not make a contribution to CPRIT or to any foundation specifically created to benefit CPRIT. 7. An applicant is not eligible to receive a CPRIT grant award if the applicant PI, any senior member or key personnel listed on the grant application, or any officer or director of the grant applicant's organization or institution is related to a CPRIT Oversight Committee member. CPRIT RFA R-21.1-RTA Research Training Awards Page 10 of $24(\operatorname{Rev} 1 / 31 / 20) 8$. The applicant must report whether the applicant institution or organization, the PI, or other individuals who contribute to the execution of the proposed project in a substantive, measurable way, whether or not those individuals are slated to receive salary or compensation under the grant award, are currently ineligible to receive federal grant funds or have had a grant terminated for cause within 5 years prior to the submission date of the grant application. 9. CPRIT grants will be awarded by contract to successful applicants. Certain contractual requirements are mandated by Texas law or by administrative rules. Although applicants need not demonstrate the ability to comply with these contractual requirements at the time the application is submitted, 
applicants should make themselves aware of these standards before submitting a grant application. Significant issues addressed by the CPRIT contract are listed in section 10 and section 11. All statutory provisions and relevant administrative rules can be found at www.cprit.state.tx.us.

\section{Level of Study: Masters}

Type: Scholarships

Value: Award: Up to US $\$ 400,000$ per year in total costs. Maximum duration: 3 years. Applicants that plan on conducting a clinical trial as part of the project may request up to US\$600,000 in total costs and a maximum duration of 4 years. Exceptions permitted if extremely well justified.

Length of Study: 3-4 years

Country of Study: US

Application Procedure: Each application must be accompanied by a letter of institutional support from the president or provost indicating support and commitment to the training program. The letter could include, but is not limited to, information about laboratory space, shared laboratory facilities and equipment, funds for curriculum development, support for additional trainees in the program, and initiatives to support recruitment of underrepresented minorities. A maximum of 3 pages may be provided. Applications that are missing 1 or more of these components, exceed the specified page, word, or budget limits, or that do not meet the eligibility requirements listed above will be administratively rejected without review. 8.3. Formatting Instructions Formatting guidelines for all submitted CPRIT applications are as follows: 1. Language: English. 2. Document Format: PDF only. 3. Font Type/Size: Arial (11 point), Calibri (11 point), or Times New Roman (12 point). 4. Line Spacing: Single. 5. Page Size: $8.5 \times 11$ inches. 6. Margins: 0.75 inch, all directions. 7. Color and High-Resolution Images: Images, graphs, figures, and other illustrations must be submitted as part of the appropriate submitted document. Applicants should include text to explain illustrations that may be difficult to interpret when printed in black and white. CPRIT RFA R-21.1-RTA Research Training Awards Page 17 of 24 (Rev $1 / 31 / 20)$ 8. Scanning Resolution: Images and figures must be of lowest reasonable resolution that permits clarity and readability. Unnecessarily large files will NOT be accepted, especially those that include only text. 9. References: Applicants should use a citation style that includes the full name of the article and that lists at least the first 3 authors. Official journal abbreviations may be used. An example is included below; however, other citation styles meeting these parameters are also acceptable as long as the journal information is stated. Include URLs of publications referenced in the application. Smith, P.T., Doe, J., White, J.M., et al (2006). Elaborating on a novel mechanism for cancer progression. Journal of Cancer Research, 135: 45-67. 10. Internet URLs: Applicants are encouraged to provide the URLs of publications referenced in the application; however, applicants should not include
URLs directing reviewers to websites containing additional information about the proposed research. 11. Headers and Footers: These should not be used unless they are part of a provided template. Page numbers may be included in the footer (see following point). 12. Page Numbering: Pages should be numbered at the bottom right corner of each page. 13. All attachments that require signatures must be filled out, printed, signed, scanned, and then uploaded in PDF format

Closing Date: 3 June

Additional Information: cpritgrants.org/

\section{Individual Investigator Research Awards for Computational Systems Biology of Cancer (IIRACSBC)}

Purpose: Supports applications for innovative mathematical and/or computational research projects addressing questions that will advance current knowledge in the (a) mechanisms that tie altered gene expression and downstream molecular mechanisms to functional cancer phenotypes and/or (b) mechanisms that tie tumor morphology to functional cancer phenotypes, and/or (c) mechanisms that tie treatment sequence and combination to evolving functional cancer phenotypes (that emerge as a result of treatment selection). Broadly speaking, functional cancer phenotypes include migratory, proliferative, metabolic and resistant cancer cell phenotypes. Partnering of mathematical or computational scientists with cancer biologists or oncologists is highly recommended to form a truly interdisciplinary team that can both develop and validate models leading to a deeper integrated understanding of cancer progression and treatment.

Eligibility: The applicant must be a Texas-based institution of higher education or a component of a university system with appropriately accredited degree-granting training programs (if support is requested for training leading to a degree). 1. The Principal Investigator (PI) must have a doctoral degree, including MD, PhD, DDS, DMD, DrPH, DO, DVM, or equivalent, and must be a full-time resident of Texas during the time the research that is the subject of the grant is conducted. 2. An institution may submit only 1 new or renewal application under this RFA during this funding cycle. An exception will be made for institutions submitting applications for cancer prevention training; in this case, institutions may submit 1 prevention training program application and 1 additional application in another aspect of cancer research (new or renewal). 3. For the purposes of this RFA, an institution is defined as that component of a university system that has its own president. 4 . There must be only $1 \mathrm{PI}$, but Co-PIs may direct individual components of the overall program described in the application. 5. An institution may apply for as many components of the training program as are appropriate for the institution. 6. An applicant is eligible to 
receive a grant award only if the applicant certifies that the applicant institution or organization, including the PI, any senior member or key personnel listed on the grant application, or any officer or director of the grant applicant's institution or organization (or any person related to 1 or more of these individuals within the second degree of consanguinity or affinity), has not made and will not make a contribution to CPRIT or to any foundation specifically created to benefit CPRIT. 7. An applicant is not eligible to receive a CPRIT grant award if the applicant PI, any senior member or key personnel listed on the grant application, or any officer or director of the grant applicant's organization or institution is related to a CPRIT Oversight Committee member. CPRIT RFA R-21.1-RTA Research Training Awards Page 10 of $24(\operatorname{Rev} 1 / 31 / 20) 8$. The applicant must report whether the applicant institution or organization, the PI, or other individuals who contribute to the execution of the proposed project in a substantive, measurable way, whether or not those individuals are slated to receive salary or compensation under the grant award, are currently ineligible to receive federal grant funds or have had a grant terminated for cause within 5 years prior to the submission date of the grant application. 9. CPRIT grants will be awarded by contract to successful applicants. Certain contractual requirements are mandated by Texas law or by administrative rules. Although applicants need not demonstrate the ability to comply with these contractual requirements at the time the application is submitted, applicants should make themselves aware of these standards before submitting a grant application. Significant issues addressed by the CPRIT contract are listed in section 10 and section 11 . All statutory provisions and relevant administrative rules can be found at www.cprit.state.tx.us.

Level of Study: Masters

Type: Scholarships

Value: Award: Up to US $\$ 400,000$ per year in total costs. Exceptions permitted if extremely well justified

Length of Study: 3 years

Country of Study: US

Application Procedure: Each application must be accompanied by a letter of institutional support from the president or provost indicating support and commitment to the training program. The letter could include, but is not limited to, information about laboratory space, shared laboratory facilities and equipment, funds for curriculum development, support for additional trainees in the program, and initiatives to support recruitment of underrepresented minorities. A maximum of 3 pages may be provided. Applications that are missing 1 or more of these components, exceed the specified page, word, or budget limits, or that do not meet the eligibility requirements listed above will be administratively rejected without review. 8.3. Formatting Instructions Formatting guidelines for all submitted CPRIT applications are as follows: 1. Language: English. 2. Document Format: PDF only. 3. Font Type/Size: Arial (11 point), Calibri (11 point), or Times New Roman (12 point). 4. Line Spacing: Single. 5. Page Size: 8.5 x 11 inches. 6. Margins: 0.75 inch, all directions. 7. Color and High-Resolution Images: Images, graphs, figures, and other illustrations must be submitted as part of the appropriate submitted document. Applicants should include text to explain illustrations that may be difficult to interpret when printed in black and white. CPRIT RFA R-21.1-RTA Research Training Awards Page 17 of 24 (Rev 1/31/20) 8. Scanning Resolution: Images and figures must be of lowest reasonable resolution that permits clarity and readability. Unnecessarily large files will NOT be accepted, especially those that include only text. 9. References: Applicants should use a citation style that includes the full name of the article and that lists at least the first 3 authors. Official journal abbreviations may be used. An example is included below; however, other citation styles meeting these parameters are also acceptable as long as the journal information is stated. Include URLs of publications referenced in the application. Smith, P.T., Doe, J., White, J.M., et al (2006). Elaborating on a novel mechanism for cancer progression. Journal of Cancer Research, 135: 45-67. 10. Internet URLs: Applicants are encouraged to provide the URLs of publications referenced in the application; however, applicants should not include URLs directing reviewers to websites containing additional information about the proposed research. 11. Headers and Footers: These should not be used unless they are part of a provided template. Page numbers may be included in the footer (see following point). 12. Page Numbering: Pages should be numbered at the bottom right corner of each page. 13. All attachments that require signatures must be filled out, printed, signed, scanned, and then uploaded in PDF format

Closing Date: 3 June

Additional Information: cpritgrants.org/

\section{Individual Investigator Research Awards for Prevention and Early Detection (IIRAP)}

Purpose: Supports applications for innovative research projects addressing questions that will advance knowledge of the causes, prevention, early-stage progression, and/or early detection of cancer. Research may be laboratory-, clinical-, or population- based, and may include behavioral/intervention, dissemination or health services/outcomes research to reduce cancer incidence or promote early detection. Competitive renewal applications accepted.

Eligibility: The applicant must be a Texas-based institution of higher education or a component of a university system with appropriately accredited degree-granting training programs (if support is requested for training leading to a degree). 1. The Principal Investigator (PI) must have a doctoral degree, including $\mathrm{MD}, \mathrm{PhD}$, DDS, DMD, DrPH, DO, DVM, or 
equivalent, and must be a full-time resident of Texas during the time the research that is the subject of the grant is conducted. 2. An institution may submit only 1 new or renewal application under this RFA during this funding cycle. An exception will be made for institutions submitting applications for cancer prevention training; in this case, institutions may submit 1 prevention training program application and 1 additional application in another aspect of cancer research (new or renewal). 3. For the purposes of this RFA, an institution is defined as that component of a university system that has its own president. 4 . There must be only $1 \mathrm{PI}$, but Co-PIs may direct individual components of the overall program described in the application. 5. An institution may apply for as many components of the training program as are appropriate for the institution. 6. An applicant is eligible to receive a grant award only if the applicant certifies that the applicant institution or organization, including the PI, any senior member or key personnel listed on the grant application, or any officer or director of the grant applicant's institution or organization (or any person related to 1 or more of these individuals within the second degree of consanguinity or affinity), has not made and will not make a contribution to CPRIT or to any foundation specifically created to benefit CPRIT. 7. An applicant is not eligible to receive a CPRIT grant award if the applicant PI, any senior member or key personnel listed on the grant application, or any officer or director of the grant applicant's organization or institution is related to a CPRIT Oversight Committee member. CPRIT RFA R-21.1-RTA Research Training Awards Page 10 of $24(\operatorname{Rev} 1 / 31 / 20) 8$. The applicant must report whether the applicant institution or organization, the PI, or other individuals who contribute to the execution of the proposed project in a substantive, measurable way, whether or not those individuals are slated to receive salary or compensation under the grant award, are currently ineligible to receive federal grant funds or have had a grant terminated for cause within 5 years prior to the submission date of the grant application. 9. CPRIT grants will be awarded by contract to successful applicants. Certain contractual requirements are mandated by Texas law or by administrative rules. Although applicants need not demonstrate the ability to comply with these contractual requirements at the time the application is submitted, applicants should make themselves aware of these standards before submitting a grant application. Significant issues addressed by the CPRIT contract are listed in section 10 and section 11 . All statutory provisions and relevant administrative rules can be found at www.cprit.state.tx.us.

\section{Level of Study: Masters}

Type: Scholarships

Value: Award: Up to of US $\$ 300,000$ per year in total costs for up to 3 years for laboratory and clinical research; Up to US $\$ 500,000$ per year in total costs for 4 years for population-based research, including implementation research designed to accelerate the adoption and deployment of sustainable, evidence-based cancer prevention and screening interventions at multiple levels and in different clinical and community settings. Exceptions permitted if extremely well justified

Length of Study: maximum duration: 3 years for laboratory and clinical research and 4 years for population-based research.

\section{Country of Study: US}

Application Procedure: Each application must be accompanied by a letter of institutional support from the president or provost indicating support and commitment to the training program. The letter could include, but is not limited to, information about laboratory space, shared laboratory facilities and equipment, funds for curriculum development, support for additional trainees in the program, and initiatives to support recruitment of underrepresented minorities. A maximum of 3 pages may be provided. Applications that are missing 1 or more of these components, exceed the specified page, word, or budget limits, or that do not meet the eligibility requirements listed above will be administratively rejected without review. 8.3. Formatting Instructions Formatting guidelines for all submitted CPRIT applications are as follows: 1. Language: English. 2. Document Format: PDF only. 3. Font Type/Size: Arial (11 point), Calibri (11 point), or Times New Roman (12 point). 4. Line Spacing: Single. 5. Page Size: $8.5 \times 11$ inches. 6 . Margins: 0.75 inch, all directions. 7. Color and High-Resolution Images: Images, graphs, figures, and other illustrations must be submitted as part of the appropriate submitted document. Applicants should include text to explain illustrations that may be difficult to interpret when printed in black and white. CPRIT RFA R-21.1-RTA Research Training Awards Page 17 of 24 (Rev 1/31/20) 8. Scanning Resolution: Images and figures must be of lowest reasonable resolution that permits clarity and readability. Unnecessarily large files will NOT be accepted, especially those that include only text. 9. References: Applicants should use a citation style that includes the full name of the article and that lists at least the first 3 authors. Official journal abbreviations may be used. An example is included below; however, other citation styles meeting these parameters are also acceptable as long as the journal information is stated. Include URLs of publications referenced in the application. Smith, P.T., Doe, J., White, J.M., et al (2006). Elaborating on a novel mechanism for cancer progression. Journal of Cancer Research, 135: 45-67. 10. Internet URLs: Applicants are encouraged to provide the URLs of publications referenced in the application; however, applicants should not include URLs directing reviewers to websites containing additional information about the proposed research. 11. Headers and Footers: These should not be used unless they are part of a provided template. Page numbers may be included in the footer (see following point). 12. Page Numbering: Pages 
should be numbered at the bottom right corner of each page. 13. All attachments that require signatures must be filled out, printed, signed, scanned, and then uploaded in PDF format

Closing Date: 3 June

Additional Information: cpritgrants.org/

\section{Research Training Awards (RTA)}

Purpose: Supports applications for integrated institutional research training programs to support promising individuals who seek specialized training in the area of cancer research. Successful applicant institutions are expected to provide trainees with broad access to research opportunities across disciplinary lines and to maintain high standards for intellectual rigor and creativity.

Eligibility: The applicant must be a Texas-based institution of higher education or a component of a university system with appropriately accredited degree-granting training programs (if support is requested for training leading to a degree). 1. The Principal Investigator (PI) must have a doctoral degree, including $\mathrm{MD}, \mathrm{PhD}$, DDS, DMD, DrPH, DO, DVM, or equivalent, and must be a full-time resident of Texas during the time the research that is the subject of the grant is conducted. 2. An institution may submit only 1 new or renewal application under this RFA during this funding cycle. An exception will be made for institutions submitting applications forcancer prevention training; in this case, institutions may submit 1 prevention traininga program application and 1 additional application in another aspect of cancer research (new or renewal). 3. For the purposes of this RFA, an institution is defined as that component of a university system that has its own president. 4 . There must be only 1 PI, but Co-PIs may direct individual components of the overall program described in the application. 5. An institution may apply for as many components of the training program as are appropriate for the institution. 6. An applicant is eligible to receive a grant award only if the applicant certifies that the applicant institution or organization, including the PI, any senior member or key personnel listed on the grant application, or any officer or director of the grant applicant's institution or organization (or any person related to 1 or more of these individuals within the second degree of consanguinity or affinity), has not made and will not make a contribution to CPRIT or to any foundation specifically created to benefit CPRIT. 7. An applicant is not eligible to receive a CPRIT grant award if the applicant PI, any senior member or key personnel listed on the grant application, or any officer or director of the grant applicant's organization or institution is related to a CPRIT Oversight Committee member. CPRIT RFA R-21.1-RTA Research Training Awards Page 10 of 24 (Rev 1/31/20) 8. The applicant must report whether the applicant institution or organization, the PI, or other individuals who contribute to the execution of the proposed project in a substantive, measurable way, whether or not those individuals are slated to receive salary or compensation under the grant award, are currently ineligible to receive federal grant funds or have had a grant terminated for cause within 5 years prior to the submission date of the grant application. 9. CPRIT grants will be awarded by contract to successful applicants. Certain contractual requirements are mandated by Texas law or by administrative rules. Although applicants need not demonstrate the ability to comply with these contractual requirements at the time the application is submitted, applicants should make themselves aware of these standards before submitting a grant application. Significant issues addressed by the CPRIT contract are listed in section 10 and section 11 . All statutory provisions and relevant administrative rules can be found at www.cprit.state.tx. us.

Level of Study: Masters

Type: Scholarships

Value: Up to US $\$ 800,000$ per year in total costs

Length of Study: 5 years

Country of Study: US

Application Procedure: Each application must be accompanied by a letter of institutional support from the president or provost indicating support and commitment to the training program. The letter could include, but is not limited to, information about laboratory space, shared laboratory facilities and equipment, funds for curriculum development, support for additional trainees in the program, and initiatives to support recruitment of underrepresented minorities. A maximum of 3 pages may be provided. Applications that are missing 1 or more of these components, exceed the specified page, word, or budget limits, or that do not meet the eligibility requirements listed above will be administratively rejected without review. 8.3. Formatting Instructions Formatting guidelines for all submitted CPRIT applications are as follows: 1. Language: English. 2. Document Format: PDF only. 3. Font Type/Size: Arial (11 point), Calibri (11 point), or Times New Roman (12 point). 4. Line Spacing: Single. 5. Page Size: $8.5 \times 11$ inches. 6 . Margins: 0.75 inch, all directions. 7. Color and High-Resolution Images: Images, graphs, figures, and other illustrations must be submitted as part of the appropriate submitted document. Applicants should include text to explain illustrations that may be difficult to interpret when printed in black and white. CPRIT RFA R-21.1-RTA Research Training Awards Page 17 of 24 (Rev $1 / 31 / 20) 1$. Scanning Resolution: Images and figures must be of lowest reasonable resolution that permits clarity and readability. Unnecessarily large files will NOT be accepted, especially those that include only text. 2 . References: Applicants should use a citation style that includes the full name of the article and that lists at least the first 3 authors. Official journal abbreviations may be used. An example is included below; however, other citation styles meeting these parameters are 
also acceptable as long as the journal information is stated. Include URLs of publications referenced in the application. Smith, P.T., Doe, J., White, J.M., et al (2006). Elaborating on a novel mechanism for cancer progression. Journal of Cancer Research, 135: 45-67. 3. Internet URLs: Applicants are encouraged to provide the URLs of publications referenced in the application; however, applicants should not include URLs directing reviewers to websites containing additional information about the proposed research. 4. Headers and Footers: These should not be used unless they are part of a provided template. Page numbers may be included in the footer (see following point). 5. Page Numbering: Pages should be numbered at the bottom right corner of each page. 6. All attachments that require signatures must be filled out, printed, signed, scanned, and then uploaded in PDF format Closing Date: 3 June

Additional Information: cpritgrants.org/

\section{Cancer Research Fund of the Damon Runyon-Walter Winchell Foundation}

Fellowship Department, 131 East 36th Street, New York, NY 10016, United States of America.

Tel: $\quad$ (1) 2125323888

Email: drwwfellow@aol.com

Contact: Ms Clare M Cahill, Assistant to the Director

\section{Cancer Research Fund of the Damon Runyon - Walter Winchell Foundation Research Fellowships for Physician Scientists}

Purpose: To augment the training of a physician scientist who has demonstrated the motivation and potential to conduct original research under the supervision of a sponsor, thus, equipping the Fellow to become an independent investigator Eligibility: Applicants must have completed at least one of the following degrees or its equivalent: MD, PhD, DDS, DVM, and have completed their residencies or clinical fellowship training within three years prior to the Scientific Advisory Committee meeting at which their applications are to be considered

Level of Study: Postdoctorate

Type: Fellowship

Value: US\$46,500 stipend for the first year, US\$47,500 for the second year and US\$49,000 for the third year. In addition, US\$2,000 expenses is awarded annually

Length of Study: 3 years, renewable annually
Frequency: 3 times each year

Study Establishment: An approved institution under a sponsor

Country of Study: Other

Application Procedure: Application form must be completed

No. of awards offered: 700

Closing Date: November

No. of awards given last year: 45

No. of applicants last year: 700

\section{For further information contact:}

Email: awards@damonrunyon.org

\section{Damon Runyon Clinical Investigator Award}

Purpose: The Damon Runyon Clinical Investigator Award supports early career physician-scientists conducting patientoriented research. The goal of this innovative program is to increase the number of physicians capable of moving seamlessly between the laboratory and the patient's bedside in search of breakthrough treatments. Damon Runyon Clinical Investigators are eligible to apply for Continuation Grants in the final year of their award.

Eligibility: Applicants must have completed at least one of the following degrees or its equivalent: $\mathrm{MD}, \mathrm{PhD}, \mathrm{DDS}$, DVM, and have completed their residencies or clinical fellowship training within three years prior to the Scientific Advisory Committee meeting at which their applications are to be considered

Level of Study: Postdoctorate

Type: Award

Value: US\$46,500 stipend for the first year, US\$47,500 for the second year and US $\$ 49,000$ for the third year. In addition, US\$2,000 expenses is awarded annually

Closing Date: November

For further information contact:

Email: awards@damonrunyon.org

\section{Cancer Research Institute}

681 Fifth Avenue, New York, NY 10022-2707, United States of America.

Email: info@cancerresearch.org

Website: www.cancerresearch.org

Contact: Grants Enquiries 


\section{Cancer Research Institute Irvington Postdoctoral Fellowship Program}

Purpose: The CRI Irvington Postdoctoral Fellowship Program supports qualified young scientists at leading universities and research centers around the world who wish to receive training in fundamental immunology or cancer immunology

Eligibility: Applicants for the CRI Irvington Postdoctoral Fellowship Program must be working in areas directly related to immunology or cancer immunology. An eligible project must fall into the broad field of immunology with relevance to solving the cancer problem. Applicants must have a doctoral degree by the date of award activation and must conduct their proposed research under a sponsor who holds a formal appointment at the host institution. Applicants with 5 or more years of relevant postdoctoral experience are not eligible, with the exception of M.D. applicants, who should not include years of residency in this calculation. Only in exceptional circumstances will applicants who have already spent 3 or more years in a sponsor's laboratory by the start date of fellowship be considered for a fellowship award. The fellowship can be performed in the United States or abroad, but must take place at a non-profit institution. There are no citizenship restrictions. Only one fellow per sponsor may apply per application round, and faculty sponsors may not have more than three CRI-supported fellows at any time

Level of Study: Doctorate, Postdoctorate

Type: Fellowships

Value: US\$175,500

Length of Study: 3 years

Frequency: Twice a year

Country of Study: Any country

Application Procedure: The application deadlines are April 1 and October 1; when those dates fall on the weekend, applications are due the following Monday. Applications are due by 5 p.m. Eastern Time on these dates. Applicants are notified of fellowship committee decisions within approximately 10-12 weeks of the application deadline. Fellowships can be activated three months after the application deadline but no later than one year following the deadline. Awards activate on the first of the month

No. of awards offered: 400

Closing Date: 1 April

Funding: Private, Individuals

No. of awards given last year: 35

No. of applicants last year: 400

Additional Information: www.biotecnika.org/2019/01/ cancer-research-institute-irvington/

\section{For further information contact:}

29 Broadway, 4th fl, New York, NY 10006, United States of America.

Tel: (1) 2126887515

Email: grants@cancerresearch.org

\section{Clinical and Laboratory Integration Program}

Purpose: The Cancer Research Institute funds research aimed at furthering the development of immunological approaches to the diagnosis, treatment, and prevention of cancer. The Institute's mission is to bring effective immune systembased therapies to cancer patients sooner. To this end, CRI offers its Clinic and Laboratory Integration Program (CLIP) Grants to qualified scientists who are working to explore clinically relevant questions aimed at improving the effectiveness of cancer immunotherapies. The program supports pre-clinical and translational research that can be directly applied to optimizing cancer immunotherapy in the clinic

Type: Grant

Country of Study: Africa

Additional Information: researchfunding.duke.edu/clinicand-laboratory-integration-program-clip

\section{For further information contact:}

Email: grants@cancerresearch.org

\section{Lloyd J. Old STAR Program}

Purpose: The Lloyd J. Old STAR Program provides grants of US\$1.25 million over 5 years to mid-career scientists. This long-term funding will not be tied to a specific research project, but rather will aim to provide a degree of flexibility and freedom for investigators to explore out-of-the-box and disruptive avenues of research. Candidates selected for this award are expected to be future "stars" in the field of cancer immunology: Scientists Taking Risks

Eligibility: Mid-career scientists: tenure-track assistant professors (minimum 3 years) and associate professors (maximum 3 years)

Level of Study: Research

Type: Grant

Value: US $\$ 1,250,000$

Length of Study: 5 years

Frequency: Annual

Country of Study: Any country 
Application Procedure: The deadline for the receipt of applications is 1 March. Candidates will be notified in early May whether or not they have been invited to the Cancer Research Institute in New York City for an interview. All invited applicants must be available for an in-person interview with members of CRI's Scientific Advisory Council. The earliest an award can activate is 1 July. Awards must activate on the first of the month

Closing Date: 1 January

Funding: Private, Foundation, Individuals

Additional Information: researchfunding.duke.edu/lloyd-jold-star-program

\section{Technology Impact Award}

Purpose: The Cancer Research Institute Technology Impact Award provides seed funding of up to US $\$ 200,000$ to be used over 12-24 months to address the gap between technology development and clinical application of cancer immunotherapies. These grants aim to encourage collaboration between technology developers and clinical cancer immunologists and to generate the proof-of-principle of a novel platform technology in bioinformatics, ex vivo or in silico modeling systems, immunological or tumor profiling instrumentation, methods, reagents and assays, or other relevant technologies that can enable clinician scientists to generate deeper insights into the mechanisms of action of effective or ineffective cancer immunotherapies

Eligibility: Applicants must hold a faculty appointment as a tenure-track assistant professor (or higher rank) at the time of award activation. The grant will be awarded to a scientist who describes an extraordinarily novel, yet practical research plan that is creative and technically sophisticated. Joint submissions from collaborators will also be considered. (The collaborators will share the award.) Each collaborator must meet the eligibility criteria

Level of Study: Research

Type: Grant

Frequency: Annual

Country of Study: Any country

Application Procedure: Letters of Intent describing the research plan will be submitted electronically by November 15. Selected applicants will be invited to submit a full research proposal with a submission deadline of March 15. Award winners will be announced on or around June 30 . Successful applicants will have their project reviewed at 12 and 24 months

No. of awards offered: 100

Closing Date: 15 November

Funding: Private, Corporation, Foundation, Trusts, Individuals
No. of awards given last year: 5

No. of applicants last year: 100

Additional Information: www.cancerresearch.org/scien tists/fellowships-grants/technology-impact-award

\section{For further information contact:}

Email: grants@cancerresearch.org

\section{Cancer Research United Kingdom}

London Research Institute, PO Box 123, Lincoln's Inn Fields, London, WC2A 3PX, United Kingdom.

Tel: $\quad$ (44) 2072693609

Website: www.cancerresearch.org

Contact: Mrs Yvonne Harman, Graduate Programme

Administrator

Cancer Research United Kingdom London Research Institute is part of CR-United Kingdom, which is a registered United Kingdom charity dedicated to saving lives through research into the causes, prevention, treatment and cure of cancer.

\section{Cancer Research United Kingdom LRI Graduate Studentships}

Purpose: To enable research training

Eligibility: Open to candidates who have normally been resident in the United Kingdom for more than 3 years and have obtained, or are about to obtain, a First or Upper Second Class (Honours) Degree in science. Applicants must also be aged 25 years or younger. Non-residents are not excluded from consideration

Level of Study: Doctorate

Type: Studentship

Value: Approx. United Kingdom £13,701-14,821 per year, depending on location

Length of Study: 3 years

Frequency: Annual

Study Establishment: Cancer Research United Kingdom LRI laboratories

Country of Study: United Kingdom

Application Procedure: Applicants must refer to the advertisements that list procedure information.

\section{For further information contact:}

Email: eric.eve@hmc.ox.ac.uk 


\section{Cancer Research United Kingdom Manchester Institute}

The University of Manchester, Wilmslow Road, Manchester, M20 4BX, United Kingdom.

Tel: (44) 1614463156

Email:_enquiries@cruk.manchester.ac.uk

Website: www.cruk.manchester.ac.uk

The CRUK Manchester Institute is a leading cancer research institute within The University of Manchester

\section{4-Year Studentship}

Purpose: To support study towards a PhD.

Eligibility: Open to candidates who have obtained a First or Second Class (Honours) Bachelor of Science Degree. International First or 2.1 degree equivalent in biological science, medicine, or related subject

Level of Study: Doctorate, Postgraduate

Type: Studentship

Value: $£ 19,000$ as stipend per year, university fees and bench fees

Length of Study: 4 years

Frequency: Annual

Study Establishment: The University of Manchester

Country of Study: United Kingdom

Application Procedure: Please visit www.cruk.manchester. ac.uk

No. of awards offered: 343

Funding: Private

Contributor: Cancer Research United Kingdom

No. of awards given last year: 5

No. of applicants last year: 343

Additional Information: All positions are advertised on the website. Self-funded students are accepted subject to qualifications and 3-year funding. Please use application form, available at website wellcome.ac.uk/funding/ schemes/four-year-phd-programmes-studentships-basicscientists

\section{For further information contact:}

Oglesby Building, 555 Wilmslow Rd, Manchester, M20 4G, United Kingdom.

Email: pgt@cruk.manchester.ac.uk

\section{Canon Collins Trust}

22 The Ivories, 6 Northampton Street, London, N1 2HY, United Kingdom.

Tel:

(44) 2073541462

Email: info@canoncollins.org.uk

Website: www.canoncollins.org.uk

Contact: Victoria Reed, Scholarships Officer

We believe that southern Africa's development depends on strong leadership in key fields. Our scholars are outstanding academics and professionals who are dedicated to the development of their countries. We seek to invest in those who share our commitment to social justice and who can demonstrate their intention to return to their home countries after their study.

\section{Canon Collins Scholarship for Distance Learning Master of Laws (LLM)}

Purpose: This scholarship allows the individual to study for the Postgraduate certificate, Post graduate diploma and Master of laws

Eligibility: Applicants for this scholarship must be a national of South Africa, Malawi, Zimbabwe or Zambia, normally resident in one of these four countries

Frequency: Annual

Country of Study: United Kingdom

Application Procedure: Check website for more details

Closing Date: 11 January

Funding: Trusts

Additional Information: scholarship-positions.com/canoncollins-scholarship-distance-learning-master-laws-llm-programuk-2015/2015/05/13/

\section{Canterbury Christ Church, University College, Graduate School}

North Holmes Road, Canterbury, CT1 1QU, United Kingdom.

Tel:

Email:

Website:

Contact: Miss Ashleigh Stuart, Research Secretary
(44) 1227767700

research@cant.ac.uk

www.cant.ac.uk 


\section{Faculty PhD Scholarships}

Purpose: Scholarships are available for doctoral projects which fall within the main research priorities of the University (healthcare and medicine; education; science and technology; creative and digital arts; business, the economy and policy) and within one of our four Faculties (Arts and Humanities, Education, Health and Wellbeing, Social and Applied Sciences).

Level of Study: Postgraduate

Type: Scholarship

Value: (a stipend of $£ 13,000$ p.a., tuition fee waiver for three years and an expense allowance of $£ 500$ p. a.).

Length of Study: 4 year

Closing Date: 17 April

Additional Information: www.canterbury.ac.uk/study-here/ postgraduate-research/funding-for-research-degrees.aspx

\section{For further information contact:}

Email:1ynn.revell@canterbury.ac.uk

\section{L.B. Wood Travelling Scholarship}

Purpose: This scholarship is available to all graduates from any university in New Zealand, from any faculty providing that the application for the scholarship is made within three years from the date of graduation. The scholarship is offered as a supplement to some other postgraduate scholarships held for the purpose of study in Great Britain

Eligibility: 1. be graduates of or graduating from a New Zealand university 2. apply for the scholarship within three years from the date of their graduation 3. have applied for or been awarded another postgraduate scholarship.

Level of Study: Postgraduate

Type: Scholarship

Value: US $\$ 3,000$

Length of Study: 3 year

Frequency: Annual

Country of Study: Any country

Application Procedure: 1. Check your eligibility. 2. Read the Regulations 3. Applications must be done online. A link to the application website is available here: universitiesnz. communityforce.com/

Closing Date: 1 April

Funding: Foundation

Additional Information: www.canterbury.ac.nz/scholarship search/ScholarshipDetails.aspx?ScholarshipID $=6935.167$

\section{For further information contact:}

Email: scholarships-cf@universitiesnz.ac.nz

\section{Lawson Robinson Hawke's Bay A\&P Scholarship}

Purpose: The Lawson Robinson Hawke's Bay A\&P Scholarship aims to recognise outstanding academic and leadership qualities in a student currently enrolled in a full time land based programme. Applicants should have a familial association with Hawke's Bay

Eligibility: New Zealand Citizen or Permanent Resident Students

Level of Study: Postgraduate

Type: Scholarship

Value: US $\$ 3,000$

Length of Study: 1 year

Frequency: Varies

Country of Study: Any country

Application Procedure: Apply online

Closing Date: 28 February

Funding: Foundation

Additional Information: www.wgtn.ac.nz/scholarships/cur rent/lawson-robinson-hawkes-bay-a-and-p-scholarship

\section{For further information contact:}

Email: awards@showgroundshb.co.nz

\section{Canterbury Historical Association}

History Department, University of Canterbury, Private Bag 4800, Christchurch 8140, New Zealand.

Tel: $\quad$ (64) 33642555

Email: david.monger@canterbury.ac.nz

Website: www.hums.canterbury.ac.nz/hist/

Contact: Mrs Lynn McClelland, Director of Student

Services and Communications

The Canterbury Historical Association (founded 1922, but in recess between 1940 and 1953) aims to foster public interest in all fields of history by holding meetings for the discussion of historical issues, and to promote historical research and writing through its administration of the J M Sherrard Award in New Zealand local and regional history.

\section{Anne Reid Memorial Trust Scholarship}

Purpose: The scholarship commemorates Anne Reid of Blenheim/Christchurch/Singapore/Auckland who studied 
and taught at the University of Canterbury and The National University of Singapore. The purpose of this scholarship is to assist a graduate student from either the University of Canterbury or the University of Auckland overseas in an environment that encourages the completion of a course or work in progress, or the undertaking of further training in a recognised institution

Level of Study: Postgraduate

Type: Scholarship

Value: NZ\$20,000

Length of Study: 1 year

Frequency: Annual

Country of Study: New Zealand

Application Procedure: Apply online

Closing Date: 30 April

Funding: Trusts

Additional Information: www.auckland.ac.nz/en/study/ scholarships-and-awards/find-a-scholarship/anne-reid-memorialtrust-scholarship-408-cai.html

\section{For further information contact:}

Email: scholarships-cf@universitiesnz.ac.nz

\section{BayTrust Bruce Cronin Scholarship}

Purpose: This scholarship has been established to recognise his service to the people of the Bay of Plenty

Eligibility: Applicants will be eligible if they were born in, or attended school in, or have whakapapa back to the area

Level of Study: Postgraduate

Type: Scholarship

Value: NZ\$5,000

Length of Study: 1 year

Frequency: Annual

Country of Study: New Zealand

Application Procedure: Apply online universitiesnz. communityforce.com/

Closing Date: 1 February

Funding: Foundation

Additional Information: www.universitiesnz.ac.nz/scholar ships/baytrust-bruce-cronin-scholarship

\section{For further information contact:}

Level 1, 752 Cameron Road, Tauranga South, Tauranga 3112, New Zealand.

Tel: $\quad$ (64) 75786546

Email: info@baytrust.org.nz

\section{Canterbury Scholarship}

Purpose: These scholarships, tenable for study towards the degree of Doctor of Philosophy at the University of Canterbury, were established to recognise students of the highest calibre undertaking $\mathrm{PhD}$ research at the university

Eligibility: To apply for a Canterbury Scholarship, please use the UC Doctoral Scholarship application form. The very top ranked domestic applicants who apply for the UC Doctoral Scholarship will be awarded one of the limited number of Canterbury Scholarships available. Domestic students who do not receive a Canterbury Scholarship will be automatically considered for the UC Doctoral Scholarship.

Level of Study: Postgraduate

Type: Scholarship

Value: NZ\$21,000

Length of Study: 3 year

Frequency: Annual

Country of Study: New Zealand

Application Procedure: See website address in additional information.

Closing Date: 15 May

Funding: Trusts

Additional Information: www.canterbury.ac.nz/scholarship search/ScholarshipDetails.aspx?ScholarshipID=6935.209

\section{For further information contact:}

Email: scholarships-cf@universitiesnz.ac.nz

\section{Clifford Wallace Collins Memorial Trust Scholarship}

Purpose: The trust fund was established in 1980 to provide an annual award to support graduates of the University of Canterbury undertaking a course of study in Librarianship at a New Zealand university, and to commemorate the contribution made to the University and its library by Clifford Wallace Collins (1909-1979). Applications, addressing the selection criteria, must be made by letter to the Information Studies Programme Director of Victoria University of Wellington by 15 April

Eligibility: The trust fund was established in 1980 to provide an annual award to support graduates of the University of Canterbury undertaking a course of study in Librarianship at a New Zealand university, and to commemorate the contribution made to the University and its library by Clifford Wallace Collins (1909-1979). Mr Collins was Librarian to Canterbury University College and the University of Canterbury from 1934 to 1971

Level of Study: Postgraduate 
Type: Scholarship

Value: NZ\$750

Length of Study: 1 year

Frequency: Annual

Country of Study: New Zealand

Application Procedure: Apply online

Closing Date: 15 April

Funding: Trusts

Additional Information: www.canterbury.ac.nz/scholarship search/ScholarshipDetails.aspx?ScholarshipID=6935.101

\section{For further information contact:}

Email: scholarships-cf@universitiesnz.ac.nz

\section{Marian D'Eve Memorial Scholarship}

Purpose: This scholarship supports students studying, researching, or developing, resources for early-childhood special-needs education at the University of Canterbury. The scholarship was established in 2009 in memory of Marian D'Eve, an early-childhood education specialist and author of a handbook for teachers

Level of Study: Postgraduate

Type: Scholarship

Value: US $\$ 2,000$

Length of Study: 1 year

Frequency: Annual

Country of Study: Any country

Application Procedure: Apply online

Closing Date: 31 March

Funding: Foundation

Additional Information: www.canterbury.ac.nz/scholarship search/ScholarshipDetails.aspx?ScholarshipID=6935.1061

For further information contact:

Email: scholarships-cf@universitiesnz.ac.nz

\section{Roger Helm Scholarship in Pure Mathematics}

Purpose: The scholarship supports students for study towards a research master's degree or a $\mathrm{PhD}$ degree in Pure Mathematics at the University of Canterbury. It was established in 2018 from a bequest by Roger Helm (1947-2015)

Eligibility: At the time of application, applicants must be enrolled in either a programme for a $\mathrm{PhD}$ degree in Pure Mathematics, or in Part II of a master's degree in Pure Mathematics. Applications are not accepted from candidates who already hold a research doctoral degree. Applications are not accepted from previous holders of the scholarship

Level of Study: Postgraduate

Type: Scholarship
Value: NZ $\$ 5,000$

Length of Study: 1 year

Frequency: Annual

Country of Study: New Zealand

Application Procedure: Apply online

Closing Date: 15 May

Funding: Trusts

Additional Information: www.canterbury.ac.nz/scholarship search/ScholarshipDetails.aspx?ScholarshipID $=6935.1764$

\section{For further information contact:}

Email: scholarships-cf@universitiesnz.ac.nz

\section{Susan Barnes Memorial Scholarship}

Purpose: The scholarship supports students with a vision impairment in undertaking study at the University of Canterbury. It was established in 2016 by the Lighthouse Vision Trust

Level of Study: Postgraduate

Type: Scholarship

Value: NZ\$10,000

Length of Study: 1 year

Frequency: Annual

Country of Study: New Zealand

Application Procedure: Apply online

Closing Date: 31 March

Funding: Foundation

Additional Information: www.canterbury.ac.nz/scholarship search/ScholarshipDetails.aspx?ScholarshipID=6935.1705

\section{For further information contact:}

Email: scholarships-cf@universitiesnz.ac.nz

\section{The Auckland Medical Aid Trust Scholarship}

Purpose: This scholarship was established in 2004 and is financed by the Auckland Medical Aid Trust to encourage research into social issues concerning being and becoming human, and provides funds for a doctoral candidate at a New Zealand university

Eligibility: An applicant will be registered as a candidate or will be in the process of registering; as a candidate for a doctoral degree at a New Zealand university. (No award will be made to a candidate who has not successfully completed; registration for a doctoral degree.)

Level of Study: Postdoctorate

Type: Scholarship

Value: NZ $\$ 25,000$

Length of Study: 3 year

Frequency: Annual 
Country of Study: New Zealand

No. of awards offered: 1

Closing Date: 1 October

Funding: Foundation

Additional Information: scholarshipdb.net/scholarships-inNew-Zealand/The-Auckland-Medical-Aid-Trust-ScholarshipAuckland-University-Of-Technology $=6 \mathrm{BYuFpD16RGUWgAlk}$ GUTnw.html?r_id=162e16e8-e590-11e9-945a-00259065139f

\section{For further information contact:}

PO Box 11915, Wellington 6142, New Zealand.

Tel: $\quad$ (64) 43818510

Email: jon.winnall@universitiesnz.ac.nz

\section{Three Nations Conference Award}

Purpose: This award assists Maori or Pasifika students, or students who are indigenous to states or territories of Australia, whose financial circumstances would otherwise preclude them from undertaking postgraduate study in the Department of Sociology and Anthropology at the University of Canterbury

Eligibility: Anthropology;Sociology

Level of Study: Postgraduate

Type: Award

Value: US $\$ 1,000$

Length of Study: 1 year

Frequency: Annual

Country of Study: Any country

Application Procedure: Apply online

Closing Date: 31 March

Funding: Foundation

Additional Information: www.canterbury.ac.nz/scholarship search/ScholarshipDetails.aspx?ScholarshipID=6935.136

\section{For further information contact:}

Email: scholarships-cf@universitiesnz.ac.nz

\section{University of Canterbury Mathematics and Statistics Scholarship}

Purpose: These scholarships recognise and support highachieving 200-, 300-, and 400-level students majoring in Mathematics, Statistics, Computational and Applied Mathematical Sciences, Data Science, Applied Data Science or Financial Engineering. The scholarships will be awarded in three categories, with the value of each category (NZ\$1,000, $\mathrm{NZ} \$ 2,500, \mathrm{NZ} \$ 5,000)$ reflecting the recipients' levels of achievement. Up to 45 scholarships will be available annually
Eligibility: By 31 March in the year of application, applicants must be enrolled full-time at the University in at least 60 points of 200-, 300-, or 400-level taught courses (not including any thesis course) for an undergraduate or postgraduate programme in: a. Applied Data Science; b. Computational and Applied Mathematical Sciences; c. Data Science; d. Financial Engineering; e. Mathematics; or f. Statistics.

Level of Study: Postgraduate

Type: Scholarship

Value: NZ\$5,000 (Category A awards) NZ\$2,500 (Category B awards) NZ $\$ 1,000$ (Category C awards)

Length of Study: 1 year

Frequency: Annual

Country of Study: Any country

Application Procedure: Apply online

Closing Date: 31 March

Funding: Foundation

Additional Information: www.canterbury.ac.nz/scholarship search/ScholarshipDetails.aspx?ScholarshipID $=6935.1592$

\section{For further information contact:}

Email: scholarships@canterbury.ac.nz

\section{Cardiff University}

Deri House, 2-4 Park Grove, Cardiff, Wales, CF10 3PA, United Kingdom.

Tel: $\quad$ (44) 2920870084

Email: graduate@cardiff.ac.uk

Website: www.cardiff.ac.uk/postgraduate

Cardiff University is recognized in independent government assessments as one of the UK's leading teaching and research universities. Founded by Royal Charter in 1883, the University today combines impressive modern facilities and a dynamic approach to teaching and research with its proud heritage of service and achievement. Having gained national and international standing, Cardiff University's vision is to be recognized as a world-class university and to achieve the associated benefits for its students, staff and all other stakeholders.

\section{Cardiff Institute of Tissue Engineering and Repair (CITER) - EPSRC Studentship}

Purpose: To support study on the MSc in Tissue Engineering at CITER 
Eligibility: Applicants must be graduates in a biomedical/ veterinary or other science subject or an engineering or clinical discipline from medicine or dentistry. United Kingdom or European Union students who have been resident in the United Kingdom for at least 3 years can apply. Other European Union participants may receive a fees only award Level of Study: Postgraduate

Type: Studentship

Value: Fees and stipend at the current EPSRC rate

Length of Study: 1 year

Application Procedure: Check website for further details

Closing Date: 30 June

For further information contact:

Tel: $\quad$ (44) 2920870129

Email: HatchS@cardiff.ac.uk

\section{Cardiff School of Chemistry - Master's Bursaries}

Purpose: To support study for the MSc in Molecular Modelling

Eligibility: Applicants must possess a 2:2 Honours Degree or equivalent in chemistry or a related discipline (e.g. physics, engineering, pharmacy, biosciences)

Level of Study: Postgraduate

Type: Bursary

Value: Cost of tuition fees at the United Kingdom/European Union rate

Length of Study: 1 year

Country of Study: United Kingdom

Application Procedure: Applicants must submit an application including two references for postgraduate study. Application forms can be downloaded from the website

Closing Date: 31 August

\section{For further information contact:}

The Postgraduate Admissions Office, The Registry, Cardiff University, 30-36 Newport Road, Cardiff CF10 3AT, United Kingdom.

Tel: (44) 2920874950

Email: platts@cardifff.ac.uk

\section{Cardiff School of Chemistry - MSc Studentships in Computing in the Physical Sciences}

Purpose: To support study on a new MSc programme in Computing in the Physical Sciences
Eligibility: Applicants must be United Kingdom-resident European Union citizens. A minimum qualification of a $2 \mathrm{ii}$ degree or equivalent in a relevant scientific discipline is required

Level of Study: Postgraduate

Type: Studentship

Length of Study: 1 year

Application Procedure: Applicants must submit an application for postgraduate study along with two references

Closing Date: 31 August

Contributor: Schools of Computer Science and Mathematics

For further information contact:

Email: platts@cardiff.ac.uk

\section{Cardiff School of City and Regional Planning - Master's Bursaries}

Purpose: To support study on the MSc in Transport and Planning

Eligibility: Applicants must have been offered and will have accepted a place on the MSc in Transport and Planning and must then be nominated for an award by the School. They must have a relevant honours degree at $2 \mathrm{i}$ or higher and they must be United Kingdom/European Union students intending to practice in the United Kingdom

Level of Study: Postgraduate

Type: Bursary

Value: Full United Kingdom/European Union fees and a maintenance stipend of $£ 1,000$ (by The Rees Jeffreys Road Fund Bursary) and £5,000 (by The Brian Largs Bursary Fund)

Length of Study: 1 year

Application Procedure: Check website for further details Closing Date: 30 June

Contributor: The Rees Jeffreys Road Fund Bursary, The Brian Largs Bursary Fund

For further information contact:

Tel: $\quad$ (44) 2920875294

Email: Yewlett@cardiff.ac.uk

\section{Cardiff School of Mathematics - PhD Studentships}

Eligibility: Applicants should hold a first or upper second class Honours degree (or overseas equivalent) in a relevant subject area or have appropriate professional experience.

Level of Study: Postgraduate 
Type: Studentship

Value: UK and EU students: $£ 9,700$, Students from outside the EU : $£ 21,950$

Length of Study: 1 year

Country of Study: United Kingdom

Application Procedure: Applicants must submit an application for postgraduate study which can be downloaded from the website

Closing Date: 30 April

Additional Information: www.cardiff.ac.uk/study/postgrad uate/taught/courses/course/mathematics-msc

\section{For further information contact:}

Cardiff School of Mathematics, Senghennydd Rd, Cardiff CF24 4AG, United Kingdom.

Tel: $\quad$ (44) 2920874813

Email: MScMaths@cardiff.ac.uk

\section{Cardiff School of Medicine - PhD Studentships}

Eligibility: Applicants must be United Kingdom/European Union students. They must possess a First or at least Upper Second Class Honours in a subject of relevance to the project (preferably biological science)

Level of Study: Postgraduate

Type: Studentship

Value: Fees support at the United Kingdom/European Union level along with a maintenance stipend at the Research Council level $(£ 12,600)$

Length of Study: PhD 3-4 years

Application Procedure: Applicants must send a covering letter and an up-to-date curriculum vitae, including a breakdown of Year 2/Year 3 university grades, along with references

Closing Date: 30 June

Contributor: School and Research Council Funds

Additional Information: www.cardiff.ac.uk/study/postgrad uate/research/programmes/programme/medicine

\section{For further information contact:}

Institute of Medical Genetics, Cardiff University, Heath Park, 210 King George V Dr E, Cardiff CF14 4ER, United Kingdom.

Tel: (44) 2920746716

Fax: (44) 2920746551

Email: pgrmedic@cardiff.ac.uk

\section{Cardiff School of Medicine - PhD Studentships (Department of Surgery)}

Eligibility: Applicants must be United Kingdom/European Union students and must possess (or be expected to obtain) a First or at least Upper Second Class Honours in a subject of relevance to the project

Level of Study: Postgraduate

Type: Studentship

Value: Fees support at the United Kingdom/European Union level plus $£ 12,600$

Length of Study: 3 years

Application Procedure: Applicants must send a covering letter and an up-to-date curriculum vitae along with references

Closing Date: 30 June

\section{For further information contact:}

Department of Surgery, Cardiff School of Medicine, Cardiff University, Heath Park, Neuadd Meirionnydd, Cardiff CF14 4YS, United Kingdom.

Tel: $\quad$ (44) $2920742895 / 2896$

Fax: (44) 2920761623

Email: JiangW@cardiff.ac.uk

\section{Cardiff School of Music - PhD Studentships}

Eligibility: Applicants must have a good Honours Degree in Music (or be expecting to obtain one in the present year) and a Master's Degree is desirable. They should be United Kingdom/European Union citizens or have been resident in the United Kingdom/European Union for at least 3 years prior to starting their $\mathrm{PhD}$.

Level of Study: Postgraduate

Type: Studentship

Value: One full studentship covering United Kingdom/European Union tuition fees and a maintenance stipend at the AHRC level $(£ 12,300)$ and another, United Kingdom/European Union fees-only studentship

Length of Study: 3 years

Application Procedure: Applicants must complete and submit an application for postgraduate study. Application forms can be downloaded from the website

Closing Date: 30 June

Additional Information: www.cardiff.ac.uk/music/courses/ postgraduate-research/postgraduate-research-scholarships

\section{For further information contact:}

School of Music, Cardiff University, Corbett Road, Cardiff, CF10 3EB, United Kingdom. 
Tel:

(44) 2920874816

Fax: (44) 2920874379

Email: musicschool@cardiff.ac.uk

\section{Cardiff School of Optometry and Vision Sciences - PhD Studentship}

Purpose: To adopt a completely new approach to understanding the relationship between retinal structure and visual function in AMD

Eligibility: Applicants must possess a United Kingdom higher education Degree at First or Upper Second Class Honours or equivalent in a relevant discipline (optometry would be most suitable)

Level of Study: Postgraduate

Type: Studentship

Value: $£ 12,600$

Length of Study: 3 years

Application Procedure: Applicants must complete and submit a standard Cardiff University application form along with a curriculum vitae and covering letter. Application forms can be downloaded from the website

Closing Date: 1 November

Additional Information: The studentship is available to United Kingdom, European Union and overseas students, but will only cover tuition fees at the European Union/United Kingdom level

\section{For further information contact:}

Email: BinnsAM@cardiff.ac.uk

\section{Cardiff University MSc/Diploma in Housing Studentship}

Purpose: To fund a postgraduate course in housing Eligibility: Studentships are available to United Kingdom applicants with a First or Upper Second Class (Honours) Degree only

Level of Study: Postgraduate

Type: Studentship

Value: University fees and maintenance grant

Length of Study: 2 years

Frequency: Annual

Study Establishment: Cardiff University

Country of Study: United Kingdom

Application Procedure: Applicants must contact the School of City and Regional Planning

Closing Date: June

\section{For further information contact:}

Cardiff School of City and Regional Planning, Glamorgan Building, King Edward VII Avenue, Cardiff, CF10 3WA, United Kingdom.

Tel: (44) 2920876092

Email: cardpd@cardiff.ac.uk

\section{Cardiff University PhD Music Studentship}

Purpose: To fund doctoral study in music

Eligibility: Applicants should have a good Honours degree in Music, be a United Kingdom or European Union citizen or have been a resident for at least 3 years for reasons other than education

Level of Study: Doctorate

Type: Studentship

Value: Tuition fees and maintenance

Length of Study: 3 years

Frequency: Annual

Study Establishment: Cardiff University

Country of Study: United Kingdom

Application Procedure: Applicants must contact the School of Music. They will need to have received an offer of a place to study before they can apply for financial support

Closing Date: June

Additional Information: www.cardiff.ac.uk/music/courses/ postgraduate-research/postgraduate-research-scholarships

\section{For further information contact:}

School of Music, 31 Corbett Road, Cardiff, CF10 3EB, United Kingdom.

Tel: $\quad$ (44) 2920874816

Fax: (44) 2920874379

Email: musicschool@cardiff.ac.uk

\section{Cardiff University PhD Social Sciences Studentship}

Purpose: To fund $\mathrm{PhD}$ study in social sciences

Eligibility: Only United Kingdom and European Union students with a First or Upper Second Class (Honours) Degree can apply for a $\mathrm{PhD}$ studentship

Level of Study: Doctorate

Length of Study: 3-4 years

Frequency: Annual

Study Establishment: Cardiff University

Country of Study: United Kingdom 
Application Procedure: Applicants must contact the School of Social Sciences. They will need to have received an offer of a place before they can apply for financial support

Closing Date: 9 June

Additional Information: www.cardiff.ac.uk/study/postgrad uate/research/programmes/programme/social-sciences

For further information contact:

School of Social Sciences, Glamorgan Building, King Edward VII Avenue, Cardiff, CF10 3WT, United Kingdom.

Tel: (44) 2920874972

Fax: (44) 2920874436

Email: graduateoffice@cardiff.ac.uk

\section{Cardiff University PhD Studentship in European Studies}

Purpose: To support students working towards a thesis in European Studies

Eligibility: All students accepted by the School of European Studies to study for a postgraduate research degree are automatically considered

Level of Study: Doctorate

Type: Studentship

Value: Full tuition fee plus stipend

Frequency: Annual

Study Establishment: Cardiff University

Country of Study: Wales

Application Procedure: Applicants must check the application guidelines available on the postgraduate webpages

Closing Date: 30 June

For further information contact:

Email: business-phd@cardiff.ac.uk

\section{Economic \& Social Research Council $(1+3)$ Sociology Studentship}

Purpose: To fund postgraduate training

Eligibility: Applicants must have a First or Upper Second

Class (Honours) Degree

Level of Study: Postgraduate

Type: Studentship

Length of Study: 1 year for MSc and 3 years for $\mathrm{PhD}$

Frequency: Annual

Study Establishment: Cardiff University

Country of Study: United Kingdom

Application Procedure: Applicants must contact the School of Social Sciences

Closing Date: June

\section{Engineering and Physical Sciences Research Council Studentships for Biophotonics}

Purpose: To support study on the new MSc in Biophotonics Eligibility: Applicants must be excellent candidates. Funding is available to United Kingdom and European Union students only Level of Study: Postgraduate

Type: Studentship

Value: Fully funded studentships include a maintenance stipend Length of Study: 1 year

Application Procedure: Applicants can apply via the standard Cardiff University postgraduate application form, which can be downloaded from the website

Closing Date: 31 July

Contributor: Cardiff School of Biosciences and Cardiff School of Physics and Astronomy

\section{For further information contact:}

Tel: $\quad$ (44) 2920870172

Email: mscbiophotonics@cardiff.ac.uk

\section{Fully-Funded PhD Studentship in Sustainable Place-Making}

Eligibility: Residency: full awards (fees plus maintenance stipend) are open to United Kingdom nationals and European Union students without further restrictions. Academic criteria: successful applicants are likely to have a very good first degree (a first or upper second class BA or BSc Honours or equivalent), and an appropriate Masters degree in a relevant subject (e.g. social sciences; environmental studies; sustainable development; environmental psychology; sociology of technology/environment; human geography), with an average mark of at least 65

Level of Study: Postgraduate, Research

Type: Studentship

Value: Full United Kingdom/European Union tuition fees, as well as a doctoral stipend matching United Kingdom Research Council National minimum $(£ 13,863$ per year for current year, updated each year)

Length of Study: 3 years

Country of Study: United Kingdom

Application Procedure: (1) Submit a complete application form for admission to doctoral study in the School of Social Sciences, submitted to the Academic Registry via the online admissions portal (www.cardiff.ac.uk/regis/general/ applyonline/index.html)

Closing Date: 17 November

Additional Information: Cardiff University reserves the right to close applications early should sufficient applications be received 


\section{For further information contact:}

Tel: $\quad$ (44) 2920870855

Email: parkinva@cardiff.ac.uk

\section{International Engineering MSc Studentship}

Purpose: To fund postgraduate study in areas of engineering Eligibility: First or Upper Second Class (Honours) Degree

Level of Study: Postgraduate

Type: Studentship

Value: $£ 1,500$

Length of Study: 1 year

Frequency: Annual

Study Establishment: Cardiff University

Country of Study: United Kingdom

Application Procedure: Applicants must contact the School of Engineering

Closing Date: June

Additional Information: There is no need to apply seperately for scholarships as eligible applicants will be considered on the basis of their application forms

\section{For further information contact:}

Admission Office, Cardiff School of Engineering, Cardiff University, Cardiff, CF24 0YZ, United Kingdom.

\section{Tel: (44) 2920874656}

Email: engineering-pg@cardiff.ac.uk

\section{Morgan E. Williams MRes Scholarship in Helminthology}

Eligibility: English language proficiency is required. Applicants must have a undergraduate degree at level 2:2 (or higher) in a relevant biological, bio medical or bio-molecular science subject. For detailed information, please visit the website

Level of Study: Postgraduate

Type: Scholarship

Value: There is one scholarship offering a reduction of $£ 2,500$ off the tuition fees for MRes Biosciences

Country of Study: United Kingdom

Application Procedure: Applicants should submit a curriculum vitae and Covering Letter to Rachel Patterson, PatersonRJ@cardiff.ac.uk

Closing Date: May

Contributor: Cardiff School of Bio sciences

Additional Information: Scholarship is offered for 1 year armacad.info/cardiff-university-school-of-biosciences-morgane-williams-mres-scholarship-in-helminthology-uk

\section{For further information contact:}

Email: BIOSI-MRes@cardiff.ac.uk

\section{PhD Studentship in Organisms and Environment at Cardiff University}

Eligibility: Residency: full awards (fees plus maintenance stipend) are open to United Kingdom nationals and European Union students who can satisfy United Kingdom residency requirements. To be eligible for the full award, European Union nationals must have been in the United Kingdom for at least 3 years prior to the start of the course for which they are seeking funding, including for the purposes of full-time education. European Union nationals who do not meet the above residency requirement are eligible for a fees only award, provided that they have been ordinarily resident in the European Union for at least 3 years prior to the start of their proposed programme of study. Academic criteria: applicants for a studentship must have obtained, or be about to obtain, a 2.1 degree or higher in microbiology, ecology, biology or other relevant discipline. If you have a 2.2 degree, but have also obtained a Masters qualification, you are also eligible. If you do not have these qualifications but you have substantial relevant postgraduate experience please contact the department holding the studentship to find out if your relevant experience is sufficient

Level of Study: Doctorate, Postgraduate, Research

Type: Studentship

Value: This studentship consists of full United Kingdom/European Union tuition fees, as well as a Doctoral Stipend matching United Kingdom Research Council National Minimum

Length of Study: 3.5 years

Frequency: Annual

Country of Study: United Kingdom

Application Procedure: To apply, please email your curriculum vitae, 2 references and relevant academic qualifications along with a covering letter to Professor Lynne Boddy at BoddyL@cf.ac.uk

Closing Date: 15 January

Additional Information: Internal interviews will be conducted before the January 30th. Shortlisted candidates will then go on to an institutional interview which will take place between February 9th and 20th. Cardiff University reserves the right to close applications early should sufficient applications be received scholarship-positions.com/phdstudentship-in-organisms-and-environment-at-cardiff-univer sity-in-uk-2015/2014/10/08/

\section{For further information contact:}

Email: BoddyL@cf.ac.uk 


\section{Postgraduate History and Archaeology Studentship}

Purpose: To fund postgraduate training in history and archaeology

Eligibility: First or Upper Second Class (Honours) Degree. Those from the United Kingdom should apply for an award from the Arts and Humanities Research Board (AHRB)

Level of Study: Doctorate, Postgraduate

Type: Studentship

Value: Tuition fees and maintenance grant

Length of Study: 1 year for Masters, 3 years for $\mathrm{PhD}$

Frequency: Annual

Study Establishment: Cardiff University

Country of Study: United Kingdom

Application Procedure: Applicants must submit an application form, which includes a research proposal and the names of two referees

Closing Date: 1 June

\section{For further information contact:}

Cardiff School of History and Archaeology, Humanities Building, Colum Drive, Cardiff, CF10 3EU, United Kingdom.

Tel: $\quad$ (44) 2920874258

Email: hisaroffice@cardiff.ac.uk

\section{The Beacon Scholarship}

Purpose: The scholarship is awarded to students from Kenya, Tanzania, and Uganda looking to study a 3-4 year undergraduate course (excluding medicine)

Eligibility: To be eligible for this scheme, candidates must be able to demonstrate: 1 . their normal residence is in Kenya, Tanzania or Uganda. 2. leadership capabilities: i. academic excellence. ii. achievement in sport, music or drama. iii. social influence and communication. iv. citizenship. 3. a capacity to study independently overseas. 4 . financial need for study, ie annual gross household income not exceeding $£ 80 \mathrm{k}$ (US\$100k). 5. that they are aged 18-21. 6. a commitment to return to their home country within one month of degree completion

Level of Study: Postgraduate

Type: Scholarship

Value: Tuition and maintenance fees

Length of Study: 3-4 year

Frequency: Annual

Country of Study: Any country

Funding: Private

Additional Information: www.studyin-uk.in/profiles/univer sity/cardiff/scholarships/523/

\section{For further information contact:}

The Beacon Scholarship Sandells House Cliftons Lane Reigate, Surrey, RH2 9RA, United Kingdom.

Email: delhi@studyin-uk.com

\section{Ursula Henriques Scholarships}

Purpose: Scholarships are available for pursuing postgraduate taught and postgraduate research programme

Eligibility: For eligibility details, please visit website http:// scholarship-positions.com/ursula-henriques-scholarships-ukeu-international-students/

Value: Cardiff University received a gift of $£ 100,000$ from Professor Henriques (1,914-2,008), a former member of staff in the Department of History and Welsh History, University College Cardiff

Frequency: Annual

Country of Study: Any country

Application Procedure: The application form can be obtained by email. Completed forms should be returned electronically to the School Postgraduate Office

Closing Date: 18 May

Contributor: Cardiff University

Additional Information: For more details, please visit website www.cardiff.ac.uk/study/postgraduate/funding/ view/Ursula-Henriques-Scholarship scholarship-positions. com/ursula-henriques-ma-phd-scholarship-cardiff-universityuk/2018/04/23/

\section{For further information contact:}

Email: share-pg@cardiff.ac.uk

\section{Carnegie Corporation of New York}

437 Madison Avenue, Ne York, NY 10022, United States of America.

Tel: $\quad$ (1) 2123713200

Website: www.carnegie.org

Andrew Carnegie envisioned Carnegie Corporation as a foundation that would promote the advancement and diffusion of knowledge and understanding. In keeping with this mandate, our work incorporates an affirmation of our historic role as an education foundation but also honors Andrew Carnegie's passion for international peace and the health of our democracy. 


\section{Next Gen Fellowship Program for Sub-Saharan African Countries}

Purpose: This fellowship is available for pursuing $\mathrm{PhD}$ research level

Eligibility: All applicants must be citizens of and reside in a sub-Saharan African country while holding a current faculty position at an accredited college or university in Ghana, Nigeria, South Africa, Tanzania, or Uganda. Applicants for any of the funding opportunities offered through this program must have a master's degree and be working toward completion of the doctoral degree. The program seeks to promote diversity and encourages women to apply. To be eligible for the US $\$ 15,000$ dissertation research fellowship, applicants must have an approved dissertation proposal but will not yet have undertaken research of 9 months or more. For detailed information, please visit website

Level of Study: Doctorate

Type: Fellowship

Value: The doctoral dissertation proposal fellowship supports short-term research costs of up to US $\$ 3,000$ to develop a doctoral dissertation proposal. The doctoral dissertation completion fellowship supports a 1 -year leave from teaching responsibilities and a stipend up to US $\$ 15,000$ to permit the completion of a dissertation that advances research on peace, security, and development topics. The doctoral dissertation research fellowship supports 9-12 months of dissertation research costs of up to US\$15,000 on a topic related to peace, security, and development

Length of Study: About 9-12 months

Country of Study: Africa

Application Procedure: The mode of applying is online. All applications must be submitted using the online application portal

Closing Date: 13 November

Additional Information: Citizens of and reside in a sub-Saharan African country while holding a current faculty position at an accredited college or university in Ghana, Nigeria, South Africa, Tanzania, or Uganda can apply for this $\mathrm{PhD}$ fellowship www.scholarshipsads.com/next-genfellowship-program-for-sub-saharan-african-countries/

For further information contact:

Email: nextgenafrica@ssrc.org

\section{Carnegie Trust}

\section{Carnegie PhD Scholarships}

Purpose: Candidates must have, or be on track to achieve, a first class Honours undergraduate degree from a Scottish institution of higher education
Eligibility: 1. You already hold, or are on track to graduate with a First Class Honours degree from one of the eligible host organisations in Scotland. 2. This undergraduate degree is in a subject related to the academic field of your proposed doctoral research. 3. You have been accepted on a doctoral programme at one of the eligible host organisations. 4. This doctoral programme will start in the coming academic year Level of Study: Graduate

Type: Scholarship

Value: $£ 16,800$ for the academic year $2019-2020$ and $£ 3,000$ for the whole tenure

Length of Study: 3 year

Frequency: Annual

Country of Study: Any country

No. of awards offered: $15-18$ each year

Closing Date: 28 February

Funding: Foundation

Additional Information: www.carnegie-trust.org/awardschemes/carnegie-phd-scholarships/

\section{For further information contact:}

Andrew Carnegie House, Pittencrieff St, Dunfermline KY12 8AW, United Kingdom.

Tel: (44) 1383724990

\section{St Andrews Society of New York Scholarships}

Purpose: The Carnegie Trust for the Universities of Scotland administers this scholarship programme for students in the United Kingdom who wish to apply for graduate study in the United States. Successful candidates are expected to be the highest caliber, both academically and in their wider personal interests

Eligibility: 1. Candidates must be Scottish by birth or descent, and have up-do-date knowledge of Scotland, Scottish current affairs and of the Scottish tradition generally. The Society expects its scholars to be good ambassadors for Scotland. 2. Either graduates of a Scottish university, Glasgow School of Art, Royal Conservatoire of Scotland, or of Oxford or Cambridge, who have completed their first degree course (so as to be qualified to graduate) not earlier than previous year. 3. Students of a Scottish university, Glasgow School of Art, Royal Conservatoire of Scotland, or of Oxford or Cambridge, who expect to complete their first degree course (so as to be qualified to graduate) in current year. 4. Preference is given to candidates who have no previous, or limited, experience of the United States and for whom a period of study in that country may provide a life-changing experience

Level of Study: Postgraduate

Type: Scholarship 
Value: US $\$ 35,000$

Length of Study: 1 year

Frequency: Annual

Country of Study: Any country

Application Procedure: Candidates apply directly to the university where they are studying in Scotland, Cambridge or Oxford. Under no circumstances should candidates apply directly to the trust.

No. of awards offered: 2 each year

Closing Date: 16 March

Funding: Private

Additional Information: www.carnegie-trust.org/awardschemes/st-andrews-society-of-new-york-scholarships/

\section{For further information contact:}

Andrew Carnegie House, Pittencrieff St, Dunfermline KY12 8AW, United Kingdom.

Tel: (44) 1383724990

Email: office@standrewsny.org

\section{Casino Mucho}

\section{Casinomucho Research Scholarship (CSR)}

Purpose: This research scholarship provide an individual with a grant to shape up and change the face of online gambling industry within the next few years

Eligibility: 1. Full time student at college/university (preferred Marketing, Business or Communication courses). 2. No entry limit per contestant. 3. Casinomucho.com employees immediate families are not eligible. 4. 3,0005,000 words essay on one of the given topic in Microsoft Word format with correct grammar, heading and punctuation.

5. The article must be plagiarism free

Level of Study: Postgraduate

Type: Scholarship

Value: $£ 500$

Frequency: Annual

Country of Study: United Kingdom

Application Procedure: 1. Students must submit their applications to scholarship [at] muchoent.com. 2. Applications should include: full name, date of birth, name or degree course, essay in Word format

Closing Date: 31 March

Funding: Private

Additional Information: casinomucho.com/scholarship/

\section{For further information contact:}

Email: scholarship@muchoent.com

\section{Catholic University of Louvain}

1, Place de l'Université, B-1348 Louvain-la-Neuve, Belgium.

Tel:

(32) 10472111

Website: www.uclouvain.be

\section{Hoover Fellowships for International Scholars}

Eligibility: Candidates must be scholars from outside Belgium, who hold a doctorate or possess equivalent qualifications and are active in the field of economic or social ethics broadly conceived. Candidates for a full fellowship must have no professional income from other sources in the period concerned. Proficiency in either English or French is required, and at least a passive knowledge in both is desirable

Type: Fellowship

Value: One full Hoover fellowship of $€ 2,000$ per month (plus social security contributions) for a duration of 3 months. Several honorary Hoover fellowships for a duration of 1 to 6 months with a contribution to housing and travelling costs of up to $€ 500$ per month

Frequency: Annual

Study Establishment: UCL

Country of Study: Belgium

Application Procedure: Applications must reach Thérèse Davio by email (therese.davio@uclouvain.be)

Closing Date: 28 February

Contributor: UCL

Additional Information: For more information, please visit www.uclouvain.be/398682.html www.hoover.org/libraryarchives/about/fellowships

\section{CEC Artslink}

291 Broadway, 12th Floor, New York, NY 10022, United States of America.

Tel (1) 2126431985

Email: info@cecartslink.org

Website: www.cecartslink.org

CEC Artslink is an international arts service organization. Our programmes encourage and support exchange of artists and cultural managers between the United States and Central Europe, Russia, and Eurasia. We believe that the arts are a society's most deliberate and complex means of communication. 


\section{ArtsLink Independent Projects}

Purpose: To provide funding to artists and arts managers who propose to undertake projects in the United States in collaboration with a United States non-profit arts organization

Eligibility: Candidates must be citizens of, and reside in, an eligible countries Albania, Armenia, Azerbaijan, Belarus, Bosnia and Herzegovina, Bulgaria, Croatia, Czech Republic, Estonia, Georgia, Hungary, Kazakhstan, Kosovo, Kyrgyzstan, Latvia, Lithuania, Macedonia, Moldova, Mongolia, Montenegro, Poland, Romania, Russia, Serbia, Slovak Republic, Slovenia, Tajikistan, Turkmenistan, Ukraine and Uzbekistan. There are no age limitations. Arts managers must be affiliated with an organization in the non-commercial sector

Type: Fellowship

Value: US $\$ 5,000$

Length of Study: 1 year

Frequency: Annual

Country of Study: United States of America

Application Procedure: Complete online application form Closing Date: December

Funding: Private, Trusts

No. of awards given last year: 5

Additional Information: Please check at www.cecartslink. org/grants/independent_projects/ www.transartists.org/air/ cec-artslink

\section{For further information contact:}

CEC ArtsLink, 435 Hudson Street, 8th Floor, New York, NY 10014, United States of America.

Email: al@cecartslink.org

\section{ArtsLink Projects}

Purpose: To support United States artists, curators, presenters, and non-profit arts organizations undertaking projects in Eastern and Central Europe, Russia, Central Asia and the Caucasus

Eligibility: Open to citizens of eligible countries: Albania, Armenia, Azerbaijan, Belarus, Bosnia and Herzegovina, Bulgaria, Croatia, Czech Republic, Estonia, Georgia, Hungary, Kazakhstan, Kosovo, Kyrgyzstan, Latvia, Lithuania, Macedonia, Moldova, Mongolia, Montenegro, Poland, Romania, Russia, Serbia, Slovak Republic, Slovenia, Tajikistan, Turkmenistan, Ukraine and Uzbekistan

Level of Study: Postgraduate

Type: Fellowship

Value: Up to US $\$ 10,000$

Length of Study: 1 year

Frequency: Annual
Application Procedure: Complete online application form Closing Date: 15 January

Funding: Private, Trusts

No. of awards given last year: 10

Additional Information: Please check at www.cecartslink. org/grants/artslink_projects/ www.cecartslink.org/grants/ artslink_projects/

\section{For further information contact:}

Tel: $\quad$ (1) 2126431985

Email: al@cecartslink.org

\section{ArtsLink Residencies}

Purpose: To create opportunities for artists and communities across the United States to share artistic practices with artists and arts managers from abroad and engage in dialogue that advances understanding across cultures

Eligibility: Applicants must be the citizens of, and reside in, eligible countries: Afghanistan, Albania, Armenia, Azerbaijan, Belarus, Bosnia and Herzegovina, Bulgaria, Croatia, Czech Republic, Estonia, Georgia, Hungary, Kazakhstan, Kosovo, Kyrgyzstan, Latvia, Lithuania, Macedonia, Moldova, Mongolia, Montenegro, Poland, Romania, Russia, Serbia, Slovak Republic, Slovenia, Tajikistan, Turkmenistan, Ukraine and Uzbekistan

Level of Study: Postgraduate

Type: Fellowship

Value: offer artists and arts managers/curators from eligible overseas countries a six-week residency at an established, non-profit arts organization in the US

Length of Study: 6 weeks

Frequency: Annual

Country of Study: United States of America

Application Procedure: 1. A completed ArtsLink International Fellowship online application form. 2. Answers to the following questions: a. Describe the current issues in your work and explain how a residency in the United States will advance your professional development as an artist or arts manager. (300 words maximum) b. Please describe previous projects that have involved engagement or participation, and explain how you plan to engage with US artists and communities during your residency. (300 words maximum) c. Please list the most important types of activities and arts events you are hoping to take part in, keeping in mind that your residency may take place in any of the 50 states of the US. (300 words maximum) d. What prior experience or contact have you had with the United States (300 words maximum) e. Have you traveled outside your country of residence to pursue research or study If so, please indicate when and where you have traveled and in what capacity. (300 words maximum) g. How will you share your ArtsLink experience with your 
home community (300 words maximum) 3 . The most recent CV or résumé (only one-page PDF file) that lists your professional accomplishments in reverse chronological order starting from the most recent one. Only one-page documents will be submitted for panel review. 4. A letter of recommendation (only one-page PDF file) from a colleague or supervisor that explains how a residency in the United States will benefit you professionally and why it is an important endeavor at this time in your career. If written in a language other than English, please include an English translation. This letter can be submitted to mtumenev@cecartslink.org separately from your application, but it must arrive within two weeks of the application deadline. No emails will be accepted unless approved by ArtsLink staff. Letters without signatures will also not be accepted. 5. If you are applying as an arts manager / curator submit a one-page PDF file with description of your organization in English. Include information about staff size and resources.

Closing Date: 30 October

Funding: Private, Trusts

Contributor: ArtsLink Residencies are funded through public and private sources including CEC ArtsLink, the National Endowment for the Arts, the Trust for Mutual Understanding, the Ohio Arts Council, the Kettering Fund and the Milton and Sally Avery Arts Foundation with additional support from the Polish Cultural Institute and the Romanian Cultural Institute

No. of awards given last year: 16

Additional Information: Please check at www.cecartslink. org/grants/artslink_residencies/ www.cecartslink.org/grants/ artslink_residencies/

\section{For further information contact:}

291 Broadway, 14th Floor, New York, NY 10007, United States of America.

Tel: $\quad$ (1) 2126431985

Fax: (1) 2126431996

\section{Center for Creative Photography (CCP)}

The University of Arizona 1030 North Olive Road, Tucson, AZ 210103, United States of America.

Tel:

$$
\text { (1) } 5206217970
$$

Email: info@ccp.library.arizona.edu

Website: www.creativephotography.org/

The Center for Creative Photography (CCP) is an archive and research centre located on the University of Arizona campus.

\section{Center for Creative Photography Ansel Adams Research Fellowship}

Purpose: To promote and support research on the Center's photograph, archive and library collections

Eligibility: Advanced scholars and researchers from any discipline are encouraged to apply. Pre-doctoral applicants must have completed coursework and preliminary examinations for the doctoral degree and must be engaged in dissertation research

Level of Study: Research

Type: Fellowship

Value: US\$5,000

Length of Study: 2-4 weeks

Frequency: Annual

Country of Study: United States of America

Application Procedure: 1. Complete the application form. Please check back in Fall for new application form. 2. Include a 500-1,000 word statement detailing your research interests and project, and how they will be advanced by study of the Center's archives, library, and print collection 3. Attach a Curriculum Vitae of no more than four pages

Closing Date: 15 January

Additional Information: Please check at www.creativepho tography.org/study-research/fellowships-internships ccp.ari zona.edu/study-research/fellowships-internships/ansel-adamsresearch-fellowship-0

\section{For further information contact:}

Center for Creative Photography, 1030 N. Olive Road, Tucson, AZ 85719, United States of America.

Tel: $\quad$ (1) 5206210050

Fax: (1) 5206219444

Email: peregoya@ccp.arizona.edu

\section{Center for Defense Information (CDI)}

1100 G Street NW, Suite 500, Washington, DC 20005-3806, United States of America.

Tel:

(1) 2023471122

Email: info@cdi.org

Website: www.cdi.org

Contact: Joe Newman, Director of Communications

The Center for Defense Information (CDI) provides responsible, non-partisan research and analysis on the social, economic, environmental, political and military components of national and global security, and aims to educate the public 
and inform policy makers about these issues. The organization is staffed by retired senior government officials and knowledgeable researchers and is directed by Dr Bruce G Blair.

\section{Center for Defense Information Internship}

Purpose: To support the work of CDI's senior staff while gaining exposure to research, issues and communications related to national security and foreign policy

Eligibility: There are no eligibility restrictions. Paid internships are available for nationals of the United States and legal immigrants

Level of Study: Unrestricted

Type: Internship

Value: US $\$ 1,000$ per month

Length of Study: $3-5$ months

Study Establishment: CDI

Country of Study: Any country

Application Procedure: Applicants must submit a curriculum vitae, covering letter, brief writing sample, transcript and two letters of recommendation

No. of awards offered: 200

Closing Date: 15 October

Funding: Private

No. of awards given last year: 12

No. of applicants last year: 200

\section{For further information contact:}

Center for Defense Information, 1779 Massachusetts Avenue, N.W., Washington, DC 20036, United States of America.

Fax: (1) 2024624559

Email: internships@cdi.org

\section{Central Queensland University}

Building 5 Bruce Highway, Rockhampton, QLD 4702, Australia.

Tel:

(61) 749309000

Email:_research-enquiries@cqu.edu.au

Website: www.cqu.edu.au

The Central Queensland University (CQU) is committed to excellence in research and innovation with a particular emphasis on issues that affect the region. CQU achieves relevance in its research goals through linkages with industry, business, government and the community and through collaboration with national and international researchers and research networks. CQU provides a range of exciting and relevant research opportunities for Masters and $\mathrm{PhD}$ candidates and is committed to excellence and quality in the research training experience of its candidates.

\section{CQUniversity Indigenous Australian Postgraduate Research Award}

Eligibility: The applicant should be an Australian citizen and must be a Aborginal or Torres Strait Islander

Level of Study: Postgraduate, Research

Type: Scholarship

Value: AU\$19,616 maximum 1 year

Frequency: Annual

Study Establishment: Central Queensland University

Country of Study: Australia

Application Procedure: For information on application procedure, check the website

Closing Date: 31 October

Funding: Government

Additional Information: This scholarship is paid fortnightly for the period of 2 years (Masters) or 3 years (PhD). Open for applications from June 30th www.cqu.edu.au/about-us/struc ture/governance/glossary/items/indigenous-australian-postgrad uate-research-award-iapra

\section{For further information contact:}

Office of Research, Building 351, Central Queensland University, Rockhampton, QLD 4702, Australia.

Tel: (61) 749232607

Fax: (61) 749232600

\section{CQUniversity Womens Equal Opportunity Research Award}

Purpose: To enable a woman to undertake full-time postgraduate research towards a PhD or Master's degree after having experienced a break in study

Eligibility: Open only to female candiates who are citizens or permanent residents of Australia and New Zealand

Level of Study: Doctorate, Postgraduate

Type: Research award

Value: AU\$19,616 (maximum per year)

Frequency: Annual

Study Establishment: Central Queensland University 
Country of Study: Australia

Application Procedure: Check website for further details

Closing Date: 31 October

Funding: Government

Additional Information: This scholarship is paid fortnightly for the period of 2 years (Masters) or 3 years (PhD). Open for applications from 1 July www.scholarshipcare.com/womensequal-opportunity-postgraduate-research-award-upra-w/

\section{CQUniversity/Industry Collaborative Grants Scheme}

Purpose: To encourage active research collaboration between the university and eligible industry partners

Eligibility: Open for candidates who are full-time members of staff (either individuals or teams) and are able to demonstrate through their track record that they have the capability to successfully complete the proposed project

Type: Grant

Value: Up to AU $\$ 10,000$ is tenable for 1 year, commencing 1 January and ending 31 December

Length of Study: 12 months

Study Establishment: Central Queensland University

Country of Study: Australia

Application Procedure: Applications must be submitted on the current application form, in the required format with the required number of copies. One original application, and one identical copy must be submitted in hard copy, and one copy must be submitted electronically, either as a word or pdf document

Closing Date: 11 August

\section{For further information contact:}

Bldg 351, Rockhampton (City) Campus, Rockhampton, QLD 4702, Australia.

Tel: $\quad$ (61) 49232601

Fax: (61) 49232600

Email:1.walker@cqu.edu.au

\section{International Student Scholarship}

Purpose: The International Student Scholarship is available to all new international undergraduate and postgraduate coursework students who meet the academic criteria at CQUniversity Australia. The Scholarship rewards successful applicants with up to the value of $20 \%$ of your tuition fees for the duration of their studies, subject to meeting terms and conditions.
Eligibility: 1. The International Student Scholarship is awarded, at the discretion of the University, to exceptional international students, undertaking on-campus, full-time degree study at CQUniversity Australia. 2. The International Student Scholarship is only available to students applying for undergraduate or postgraduate coursework. 3. The International Student Scholarship is only available for full degree courses (full bachelor or masters only). 4. The International Student Scholarship is only available to students new to CQUniversity Australia - it is not available to students who are currently studying at CQUniversity Australia. Students currently studying at CQUniversity and applying for Change of Course will also not be eligible for the International Student Scholarship. 5. The International Student Scholarship is not available in conjunction with any other CQUniversity Australia scholarship. 6. The International Student Scholarship is not available to any student who has been given entrance to CQUniversity Australia based on work experience. 7. The International Student Scholarship is not transferable to a third party or redeemable for cash. 8. The International Student Scholarship is calculated and applied on a per term basis.

Level of Study: postgraduate

Type: SCHOLARSHIP

Value: $20 \%$ of tuition fees

Closing Date: 31 December

Additional Information: www.cqu.edu.au/courses/futurestudents/scholarships/offerings/international-student-scholarship

\section{Merit Grants Scheme}

Purpose: To provide opportunities for individuals or groups with well established or developing track records in research to initiate high quality research projects

Eligibility: Members of the full-time staff of the University with a proven research record 'relative to opportunity' are eligible to compete for Merit Research Grants. Candidates must not be absent for a period exceeding eight weeks during the proposed period of grant. A researcher may be in receipt of only one Merit Grant at any one time

Type: Grant

Value: AU\$10,000-30,000

Length of Study: 1 year

Study Establishment: Central Queensland University

Country of Study: Australia

Application Procedure: Applications must be submitted on the current application form, in the required format, and with the required number of copies

Funding: Government

Additional Information: A researcher may be in receipt of only one Merit Grant at any one time 


\section{Research Administration Assistants Postdoctoral Award}

Purpose: To provide for the university's intellectual environment by facilitating mentoring, team building, and career development in areas of current or future research strength

Eligibility: The applicant must remain based on a Central Queensland University campus (excluding international campuses) for the duration of the award

Level of Study: Postdoctorate

Type: Award

Value: On-costs of $28 \%$ will be paid in addition to salary

Frequency: Annual

Study Establishment: Central Queensland University

Country of Study: Australia

Application Procedure: Applications must be submitted on the current application form, in the required format, and with the required number of copies

Funding: Government

Additional Information: Applicants may seek funding for 1,2 , or 3 years

\section{Seed Grants Scheme}

Purpose: To provide seed funding to encourage new research-trained staff to undertake a funded research project Eligibility: Open to newly trained researchers, who are currently within the first 5 years of academic or other researchrelated performance allowing uninterrupted, stable research development following completion of their postgraduate research training

Level of Study: Research

Type: Grant

Value: Up to AU $\$ 10,000$

Length of Study: 1 year

Study Establishment: Central Queensland University

Country of Study: Australia

Application Procedure: Applications must be submitted on the current application form, in the required format, and with the required number of copies

Closing Date: 11 August

Funding: Government

\section{Centre de Recherches et} d'Investigations Epidermiques et Sensorielles

20 rue Victor Noir, F-92200 Neuilly-sur-Seine, France.

Tel:

(33) 146434900

Email: contact@ceries.com

Website: www.ceries.com
CERIES (Centre de Recherches et d'Investigations Epidermiques et Sensorielles or Centre for Epidermal and Sensory Research and Investigation) is the healthy skin research centre of Chanel.

\section{Centre de Recherches et d'Investigations Epidermiques et Sensorielles Research Award}

Purpose: To honour a scientific researcher for a fundamental or clinical research project in the field of healthy skin

Eligibility: There are no eligibility restrictions

Level of Study: Research

Value: $€ 40,000$

Length of Study: 1 year

Frequency: Annual

Country of Study: Any country

Application Procedure: Applicants must consult the website

No. of awards offered: 26

Closing Date: 1 June

Funding: Private

Contributor: Chanel

No. of awards given last year: 1

No. of applicants last year: 26

Additional Information: www.nature.com/naturecareers/ events/event $/ 8348$

For further information contact:

Email: chanelrt.award@ruderfinnasia.com

\section{Centre De Science Humaines (CSH)}

2 Aurangzeb Road, New Delhi 110011, India.

Tel: $\quad$ (91) 1130410070

Email:_direction@csh-delhi.com

Website: www.csh-delhi.com

The Centre de Sciences Humaines (CSH), created in 1989, is a research centre funded by the French Ministry of Foreign Affairs

\section{Centre de Sciences Humaines Post-Doctoral Fellowship}

Purpose: To question the status of India as an emerging power in the international scene 
Eligibility: Open to candidates who hold a PhD in economics/ economic geography/urban studies and are prefereable below 35 years of age

Level of Study: Postdoctorate

Type: Fellowship

Value: Indian Rupees 20,000-25,000 per month

Length of Study: 1 year

Frequency: Annual

Country of Study: India

Application Procedure: Applicants must send their curriculum vitae, 2 academic references letters, a synopsis of the $\mathrm{PhD}$ theses and a comprehensive research proposal

Closing Date: 31 January

Additional Information: calenda.org/203026

\section{For further information contact:}

Email: veronique.dupont@esh-delhi.com

\section{Centre for Clinical Research Excellence}

Centre for Clinical Research Excellence - Infection and Bioethics in Haematological Malignancies, Level 3, ICPMR, Westmead Hospital, Institute Road, Westmead, NSW 2145, Australia.

Tel: $\quad$ (61) 98456255

Email: cjordens@med.usyd.edu.au

Website: www.ccre-ibhm.org.au

The Centre for Clinical Research Excellence (CCRE) is multi-centre research collaboration with a special focus on bioethics, consisting of four research sites affiliated with the University of Sydney

\section{Postgraduate Scholarships for Interdisciplinary Bioethics Research}

Purpose: To develop surveillance methods and interventions to improve infection-related outcomes in malignant haematology and bone marrow transplantation, with interdisciplinary bioethics research underpinning all major themes Eligibility: Open to Australian citizens or permanent resident meeting the standard criteria for NHMRC scholarships, including full-time enrollment and status, as well as the criteria for admission to postgraduate study in the faculty of medicine or faculty of science at the University of Sydney

Level of Study: Graduate

Type: Scholarship

Country of Study: Australia

Application Procedure: Check website for further details

\section{For further information contact:}

Tel: (61) 434070788

\section{Centre for Environment Planning and Technology University}

Kasturbhai Lalbhai Campus, University Road, Vasant Vihar, Navrangpura, Ahmedabad, Gujarat 380009, India.

Contact: CEPT University

Centre for Environmental Planning and Technology University, formerly the Centre for Environmental Planning and Technology, is an academic institution located near university area in Ahmedabad, India offering postgraduate programmes in areas of the natural and developed environment of human society and related disciplines.

\section{Full-Tuition Fees Waiver for MPhil/PhD Students}

Purpose: Scholarships are available for pursuing MPhil/PhD programme

Eligibility: Students from India are eligible to apply

Type: Grant

Value: The university offers full tuition fees waiver to $\mathrm{MPhil} / \mathrm{PhD}$ students for their entire term of registration in the program. The university also offers a scholarship (Rs. 36,700 per month-subject to change) for the first six months (mandatory) of the coursework against teaching assignments (15-20 hours/week) as allocated by the respective faculty

Country of Study: India

Application Procedure: Go to the Centre for Environmental Planning and Technology(CEPT) website Click on the 'Admissions' button (on the header menu) at the top of the page. This will open a page with all the programs offered at CEPT University. Click on the program you wish to apply. This will open the tab with 'About' 'FAQ' \& 'How to Apply'. Click on the 'How to Apply' button and you will be redirected to a page containing eligibility criteria, program details and the link to the admissions portal. For further information, kindly check the following link. cept.ac.in/2/37/faculty-ofarchitecture/479/fees-scholarship

Closing Date: 30 April

Additional Information: For detailed information, check with the below link. scholarship-positions.com/full-tuition-feeswaiver-mphil-phd-students-cept-university-india/ scholarshippositions.com/full-tuition-fees-waiver-mphil-phd-students-ceptuniversity-india/2018/04/24/ 


\section{For further information contact:}

Harvard Square, Mifflin Pl, Cambridge, MA 02138, United States of America.

\section{Centre for Groundwater Studies (CGS)}

GPO Box 2100, Adelaide, SA 5001, Australia.

Tel: $\quad$ (61) 882015632

Email: cgs@groundwater.com.au

Website: www.groundwater.com.au

Centre for Groundwater Studies (CGS) is an international leader in water and environmental research and education.

\section{Chinese Government Scholarship Water and Environmental Research Scholarships}

Purpose: To assist students with research projects in the specified areas

Eligibility: Open to Australian citizens and permanent residents who have a background in science, mathematics or engineering

Level of Study: Postgraduate

Type: Scholarship

Value: AU $\$ 22,231$

Length of Study: 1 year

Frequency: Annual

Country of Study: Australia

Closing Date: September

Additional Information: For additional information see the website

For further information contact:

Email: impt@scholars4dev.com

\section{Chandigarh University}

NH-95 Chandigarh-Ludhiana Highway, Mohali, Punjab 140413, India.

Contact: Chandigarh University

A renowned university in India is offering scholarships for brilliant but less privileged students across the globe who have interest in studying in India.

\section{Chandigarh University Scholarships in India}

Purpose: Chandigarh University offers undergraduate and post-graduate and doctorate courses in various disciplines including Engineering, Management, Computing, Education, Animation and Multimedia, Tourism, Pharma Sciences, Biotechnology, Architecture, Commerce and Legal Studies Eligibility: Students outside India, Nepal and Bhutan can apply for these scholarships. Not Required but all academic documents are to be sent to micheal.africa-at-cumail.in for eligibility checking. Not required but the applicant must be able to read, write and understand the English Language

Level of Study: Graduate, Postgraduate

Value: It is between $15 \%$ and $50 \%$ (maximum) for tuition fees only

Study Establishment: Scholarships are awarded to study the subjects offered by the university

Country of Study: India

Application Procedure: Interested students can contact Mr. Michael on micheal.africa@cumail.in

Closing Date: July

Additional Information: For more details please contact the website scholarship-positions.com/chandigarh-universityscholarships-india/ www.shiksha.com/university/cuchandigarh-university-45668/scholarships

\section{For further information contact:}

Email: micheal.africa@cumail.in

\section{Charles Babbage Institute (CBI)}

211 Andersen Library, University of MN 222 21st Avenue South, Minneapolis, MN 55455, United States of America.

Tel: (1) 6126245050

Email:_cbi@umn.edu

Website: www.cbi.umn.edu

The Charles Babbage Institute (CBI) is a research centre dedicated to promoting the study of the history of computing, its impact on society and preserving relevant documentation. CBI fosters research and writing in the history of computing by providing fellowship support, archival resources and information to scholars, computer scientists and the general public.

\section{Adelle and Erwin Tomash Fellowship in the History of Information Processing}

Purpose: To advance the professional development of historians in the field 
Eligibility: 1. Must be a graduate student or a postgraduate student 2. Must attend a university 3 . Must not be attending high school currently 4. Must study full-time 5 . Restricted to students studying Computer Science/Data Processing, Electrical Engineering/Electronics, Engineering/Technology, History, Humanities, Science, Technology, and Society

Level of Study: Doctorate

Type: Fellowship

Value: US $\$ 14,000$

Length of Study: 1 year

Frequency: Annual

Country of Study: Any country

Application Procedure: 1. Recommendations or References

2. Other - Research proposal 3. Resume 4. Transcript

No. of awards offered: 1

Closing Date: 15 January

Funding: Private

Additional Information: Please check at www.cbi.umn.edu/ research/tfellowship.html www.petersons.com/scholarship/ adelle-and-erwin-tomash-fellowship-in-the-history-of-inform ation-processing-111_150883.aspx

\section{For further information contact:}

University of Minnesota 211 Elmer Andersen Library, 222-21st Avenue, South, Minneapolis, MN 55455, United States of America.

Tel: $\quad$ (1) 6245050

Fax: (1) 6126258054

Email: cbi@tc.umn.edu

\section{Charles Darwin University}

Charles Darwin University 21 Kitchener Dr, Darwin City, NT 0800, Australia.

Tel: $\quad$ (61) 889466666

Website: www.cdu.edu.au/

Charles Darwin University is a new world university built on social justice, sustainability, creativity and collective effort.

\section{CDU Vice-Chancellor's International High Achievers Scholarships}

Purpose: Charles Darwin University (CDU) offers the ViceChancellor's International High Achievers Scholarships to international students who have a record of academic excellence and high achievement and who are seeking to commence an Undergraduate or Postgraduate coursework degree at CDU.

Eligibility: Eligible applicants must: 1. Applicant must apply to commence study in 2020 2. Applicants must meet the University's academic and English language entry requirement for their chosen course; 3. Applicant must have a minimum overall score of $85 \%$ in their highest completed qualification; 4. Applicant must be an international student on a student visa; 5. Applicant must not hold another scholarship from an Australian or foreign sponsoring agency Please note: the VCIHAS scholarships are very competitive and meeting the minimum eligibility standards described above does not guarantee that you will be awarded a scholarship.

Level of Study: Bachelors/Masters Degree

Type: Scholarships

Value: $25 \%$ or $50 \%$ of the tuition fee. The tuition scholarships apply to the tuition fees for the full duration of the degree.

Frequency: annual

Country of Study: Australia

Application Procedure: To apply, you must complete the scholarship application form and submit it together with your application for admission to a degree program at CDU

No. of awards offered: Limited

Closing Date: 15 May

Additional Information: www.cdu.edu.au/international/ future-students/scholarships

\section{Charles Darwin University (CDU)}

Charles Darwin University Ellengowan Drive, Casuarina, NT 0811, Australia.

\section{Tel: $\quad$ (61) 889466666}

Email: scholarships@cdu.edu.au

Website: www.cdu.edu.au

The Charles Darwin University (CDU) offers programmes from certificate level to $\mathrm{PhD}$, incorporating the full range of vocational education courses. CDU has a distinctive research profile, reflecting the priorities appropriate to its location. It is a participating member of several CRCs.

\section{Nanyang Technological University MBA Programme}

Length of Study: 1 year, 18 months or 4 years Application Procedure: Applicants must submit, with their application form, three recent passport sized photographs, official copies of degrees and professional qualifications, two references in sealed envelopes, evidence of finance, TOEFL and IELTS scores (overseas applicants only) 


\section{For further information contact:}

Tel: $\quad$ (61) 889466447

Fax: (61) 889466777

Email: busgrad@business.ntu.edu.au

\section{Vocational Education and Training (VET) Distinction Scholarship}

Purpose: CDU Global offers a limited number of VET Distinction Scholarships to international students who come from China PRC, Indonesia or the Philippines and have a record of academic excellence and high achievement.

Eligibility: 1. Applicant must apply to study a Certificate III or higher VET qualification. 2. Applicant must be from China PRC, Indonesia or the Philippines. 3. Applicants must meet the University's academic and English language entry requirements for their chosen program. 4. Applicant must have a minimum overall score of $80 \%$ in their highest completed qualification. 5. Applicant must be classified as an International student on a student visa. 6. Applicant must be able to obtain a recommendation letter from a government sponsor, employer or partner institution of CDU. 7. Applicant should not hold another scholarship from an Australian or foreign sponsorship agency.

Level of Study: Postgraduate

Type: scholarship

Value: US $\$ 3,000$

Length of Study: 1 year

Application Procedure: 1. Step 1: Submit your application to study with CDU in July through Studylink: student-cdu. studylink.com/ and make note of your application reference number. 2. Step 2: Complete and submit the online application form (this will be live as of the 24/3/20, please email: international@cdu.edu.au if you would like to be alerted when it is live). You will need to record your Studylink reference number and submit all the required items listed in the criteria at the time of completing your application.

Closing Date: 6 May

Additional Information: www.cdu.edu.au/international/ how-apply/scholarships

\section{Charles Sturt University (CSU)}

Charles Sturt University Boorooma Street, Locked Bag 588, Wagga Wagga, NSW 2678, Australia.

Tel: $\quad$ (61) 263386077

Email: inquiry@csu.edu.au

Website: www.csu.edu.au
CSU is one of the leading Australian universities for graduate employment and largest provider in distance education. Utilizing our expertise in distance education, CSU provides educational opportunities to students around the world. Around 36,000 students undertake their choice of study with CSU on one of our campuses, from home, their workplace or anywhere around the globe.

\section{Australian Postgraduate Awards}

Purpose: To financially support postgraduate students of exceptional research promise in Master or Doctoral programs at Charles Sturt University

Eligibility: Awards will only be available to those who are Australian citizens and New Zealand citizens; have been granted permanent resident status by October 31st; have lived in Australia continuously for at least 12 months prior to October 31 st; have completed at least 4 years of tertiary education studies at a high level of achievement; have obtained First Class Honours or equivalent results; will undertake a Master's (Honours) or Doctoral degree; are enroling as full-time students or, in exceptional circumstances, be granted approval by CSU for a part-time award; have had their enrolment into the proposed higher degree programme accepted by CSU

Level of Study: Postgraduate, Research

Type: Award

Value: US $\$ 32,500$ per year

Length of Study: 2-3 years

Frequency: Annual

Study Establishment: Charles Sturt University

Country of Study: Australia

Application Procedure: Applicants must submit an application form

Closing Date: 31 October

Funding: Government

Additional Information: Please check at www.csu.edu.au/ research/support/research-students/my-hdr/getting-started/ scholarship-opportunities/main-round

\section{For further information contact:}

Email: rgs@latrobe.edu.au

\section{Biology of Annual Ryegrass Scholarship}

Purpose: To characterize annual ryegrass in Australian winter cropping areas

Eligibility: Open only for the citizens of Australia or permanent residents those who have a background in agriculture, biology, or plant science and achieved Honours 2a or equivalent

Level of Study: Graduate 
Value: AU $\$ 24,616$ (maximum per year) paid fortnightly for the period of 3 years

Country of Study: Australia

\section{For further information contact:}

Charles Sturt University, Wagga Wagga, Boorooma St, North Wagga Wagga, NSW 2650, Australia.

Tel: (61) 269332862

Email: jpratley@csu.edu.au

\section{Charles Sturt University Postgraduate Research Studentships (CSUPRS)}

Purpose: To support high quality research students in Masters or Doctoral programs at Charles Sturt University

Eligibility: Open to the candidates who hold or expect to hold, at least a Bachelor degree with upper second class honours or a qualification deemed equivalent from CSU

Level of Study: Graduate, Research

Type: Studentship

Value: US $\$ 22,500$ stipend plus allowances

Frequency: Annual

Application Procedure: Scholarship application form can be downloaded from the website. Send in the filled application to the center with original referee report and five copies of their report

Closing Date: 30 October

Additional Information: Offers of scholarships cannot be made to candidates until their enrolment as Research Higher Degree students has been approved by the Board of Graduate Studies. Please check at www.csu.edu.au/research/support/ research-students/my-hdr/getting-started/scholarship-opportun ities/main-round www.gooduniversitiesguide.com.au/scholar ships/csu-postgraduate-research-scholarship-csuprs/charlessturt-university/12142

\section{For further information contact:}

Postgraduate Scholarships, Center for Research \& Graduate Training, Charles Sturt University, Locked Bag 588, Wagga Wagga, NSW 2678, Australia.

Tel: $\quad$ (61) 269334162

Email: pgscholars@csu.edu.au

\section{Evidence-Based Approach to Improve Insulin Sensitivity in Horses, Using Dietary Ingredients}

Eligibility: Open only for the citizens of Australia or permanent residents those who have achieved Honours 1 (Semester 1)
Level of Study: Graduate

Value: AU $\$ 19,231$ (maximum per year) paid fortnightly for the period of 3 years and to be used for living expenses

Country of Study: Australia

\section{For further information contact:}

Charles Sturt University, Locked Bag 588, Wagga Wagga, NSW 2678, Australia.

Tel: $\quad$ (61) 269334242

Email: gnoble@csu.edu.au

\section{Full-time scholarship (Australian Government's Research Training Program)}

Eligibility: 1. Commencing a CSU HDR program, or currently enrolled. 2. Enrolling/enrolled as a full-time student. 3. Are enrolled concurrently in any other program, unless it is essential to the success of the HDR, or exceptional circumstances exist and are approved. 4. Are receiving another Commonwealth-funded postgraduate research scholarship.

Level of Study: Postgraduate

Type: scholarship

Value: This scholarship is valued at US\$28,092 per annum, payable in fortnightly instalments.

Length of Study: 2 or 3 years

Closing Date: 1 May

Additional Information: research.csu.edu.au/study-with-us/ scholarships/full-time-scholarship-agrtp

\section{Charlie Trotter Culinary Education Foundation}

40 E. Chicago Avenue, Suite 418, Chicago, IL 60611, United States of America.

\section{Tel: $\quad$ (1) 3126009724}

Email: info@charlietrotters.com

Website: www.charlietrotters.com/about/foundation.asp

Charlie Trotter's is regarded as one of the finest restaurants in the world, dedicated to excellence in the culinary arts. It has been instrumental in establishing new standards for fine dining. Its main goal is to educate and expose youth to the great culinary arts in as many ways as possible. The Charlie Trotter Culinary Education Foundation, a non-profit organization, has been established to promote culinary arts among 
youth. The foundation is involved in awarding scholarships to students who are seeking careers in the culinary arts and working with Chicago-area youth to promote the enthusiastic quest for education as well as an interest in the cooking and food.

\section{Charlie Trotter's Culinary Education Foundation Culinary Study Scholarship}

Eligibility: Open to an Illinois resident at the time of application

Level of Study: Professional development

Type: Scholarship

Value: US $\$ 5,000$ cash scholarship for a pre-enroled student

Length of Study: 1 year

Frequency: Annual

Country of Study: United States of America

Application Procedure: Check website for further details

Closing Date: 1 March

Funding: Private, Foundation

Contributor: Charlie Trotter's

Additional Information: Please check website for more details

\section{For further information contact:}

The Culinary Trust Scholarship Program P.O. Box 273, New York, NY 10013, United States of America.

Tel: $\quad$ (1) 6462246989

Email: cholarships@theculinarytrust.com

\section{Chiang Ching Kuo Foundation for International Scholarly Exchange}

13F, 65 Tun Hwa South Road, Section 2, 106-ROC, Taiwan, China.

Tel:

Email:

(886) 227045333

Website:

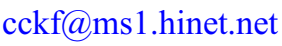

www.cckf.org

The Chiang Ching Kuo Foundation for International Scholarly Exchange is a non-profit organization headquartered in Taipei, the capital of the Republic of China. The Foundation was established in 1989 in honour of the late President Chiang Ching kuo. The main objective of the Foundation is to promote the study of Chinese culture and society, broadly defined.

\section{Chiang Ching Kuo Foundation Doctoral Fellowships}

Purpose: To financially support Doctoral candidates while writing their dissertations

Eligibility: Open to applicants who have completed all other requirements for their $\mathrm{PhD}$ degree except the dissertation. Candidates must not be employed or receive grants from other sources

Level of Study: Doctorate

Type: Fellowships

Value: Up to US $\$ 15,000$

Length of Study: 1 year

Frequency: Annual

Application Procedure: Applicants need to submit a 1 page summary of the proposed project, budget, curriculum vitae and detailed description of the proposed project along with the application form. Application forms are available online

No. of awards offered: 104

Closing Date: 15 October

Funding: Commercial, Private

No. of awards given last year: 28

No. of applicants last year: 104

\section{Chiang Ching Kuo Foundation for International Scholarly Exchange Eminent Scholar Lectureship}

Purpose: To sponsor eminent foreign scholars to come to Taiwan to take up lectureships or positions as visiting scholars

Eligibility: Open to eminent scholars invited by universities or academic institutions of Taiwan

Type: Lectureship/Prize

Value: New Taiwan NT\$2,000,000

Length of Study: 1 year

Frequency: Annual

Study Establishment: Universities or academic institutions in Taiwan

Country of Study: Taiwan

Application Procedure: Applicants must use the application forms provided by the Foundation. The application must be sent by registered mail to the Secretariat. Electronic version of all application materials must be enclosed on diskette or sent as email attachment to cckf@ms1.hinet.net with heading 'Application Materials from (Name)' in the header of the message. Applications are accepted from June 1st

Closing Date: 15 October

Funding: Foundation

Additional Information: Project directors who are currently receiving Foundation aid are ineligible to apply. Project directors may not submit more than one application 


\section{Chiang Ching Kuo Foundation for International Scholarly Exchange Publication Subsidies}

Purpose: To assist in the final stages of publishing academic works

Eligibility: Open to scholars in the final stages of publishing academic works. Applications from scholars affiliated with institutions in Taiwan must involve cooperation with one or more scholars from other countries. Applicants for publication subsidies must be affiliated with a university or other academic institution

Type: Grant

Value: Ranges between New Taiwan NT\$5,000 and NT\$10,000. Publication Subsidy Grants may only be used to cover editing, indexing, and other relevant publication costs. Translation and research-related expenses may not be included

Application Procedure: Applicants must use the application forms provided directly from the Foundation Secretariat. Three copies of the application and supporting documents must be submitted by registered mail to the Secretariat. In addition, electronic version of all application materials must be enclosed on diskette or sent as email attachment to cckf@ms1.hinet.net with heading 'Application Materials from (Name)' in the header of the message

Closing Date: 15 September

Funding: Trusts

Additional Information: Please check the website for more details

\section{For further information contact:}

The Chiang Ching-kuo Foundation for International Scholarly Exchange, 8361 B Greensboro Dr. McLean, VA 22102, United States America.

Email: cckfnao@aol.com

\section{Doctoral Fellowships}

Purpose: Supporting doctoral candidates for completing their dissertation in the last stage of their doctoral programs

Eligibility: Applicants should have completed all other requirements for their $\mathrm{PhD}$ degree. Applicants should be enroled in an accredited university in the United States, Canada, Mexico, and Central and Southern America

Level of Study: Doctorate

Type: Fellowship

Value: US\$18,000

Length of Study: 1 year

Frequency: Annual

Closing Date: 15 October
Funding: Foundation

Additional Information: www.cckf.org/en/programs/ameri can/doctoral-fellowships

\section{Junior Scholar Grants}

Purpose: The Foundation provides grants for time off for research and writing to postdoctoral and assistant professors without tenure who are affiliated with an accredited American university and who have taught for no more than 6 years since receiving $\mathrm{PhD}$ degree

Eligibility: Junior Scholar Grants is only available for applicants who are affiliated with an American university

Type: Grant

Value: Up to US\$30,000

Frequency: Annual

No. of awards offered: 80

Closing Date: 15 October

Funding: Foundation

No. of awards given last year: 20

No. of applicants last year: 80

\section{Scholar Grants}

Purpose: To help replace half of the salary of faculty on sabbatical, or for time off for research and writing

Eligibility: Tenure faculty, including full professors and associate professor, in the accredited universities in the United States, Canada, Mexico, and Central and Southern America are eligible to apply for scholar grants

Type: Grant

Value: US\$40,000 or US\$35,000

Frequency: Annual

No. of awards offered: 42

Closing Date: 15 October

No. of awards given last year: 12

No. of applicants last year: 42

Additional Information: www.cckf.org/en/programs/ameri can/scholar

\section{Chicago Tribune}

435 North Michigan Avenue, Chicago, IL 60611, United States of America.

Tel:

Email: jwoelffer@tribune.com

Website: www.chicagotribune.com 
The Chicago Tribune is the Midwest's leading newspaper. The Chicago Tribune Literary Awards are part of a continued dedication to readers, writers and ideas.

\section{Nelson Algren Awards}

Purpose: To award writers of short fiction

Eligibility: Each entrant must be at least 18 years old and a legal resident of the contest area (above) as of the date of entry

Level of Study: Unrestricted

Type: Award

Value: one grand prize winner (US\$3,500) and five finalists (US\$750)

Frequency: Annual

Country of Study: Any country

Application Procedure: Visit algren.submittable.com (the "Contest Page"), complete an entry form with the following required information: (a) name, (b) telephone number, (c) email address, (d) the title and word count of your submission, and submit it along with your short story (a "Story") (together with the entry form referred as an "Entry") that otherwise meets all Submission Requirements below. Entries will not be accepted through any other method

Closing Date: 17 February

Funding: Corporation

Additional Information: Please contact to Chicago Tribune for latest updates. Please check at articles.chicagotribune. com/2013-11-26/news/chi-2013-nelson-algren-award-officialrules-20120906_1_grand-prize-enter-or-win-chicago-tribunecompany-llc www.chicagotribune.com/entertainment/books/ literary-awards/ct-algren-contest-announcement-2019-20181 121-story.html\#nt=standard-embed

\section{For further information contact:}

Chicago Tribune, Nelson Algren Awards, 435 N. TT200, Michigan Avenue, Chicago, IL 60611, United States of America.

Email: printersrow@tribune.com

\section{Chilean International Cooperation Agency}

\section{Chile: Nelson Mandela Scholarships}

Purpose: The Chilean International Cooperation Agency (AGCI) is offering scholarships for accredited Spanish-taught Master's program at Chilean higher education institutions. The scholarships are offered to professionals who are citizens of South Africa, Mozambique and Angola
Eligibility: 1. Experience in the subjects they choose to pursue Master's studies in unconditional acceptance offer at a Chilean higher education institution. 2. 4-year university degree. 3. If employed already, you will need a letter of support, indicating that you will be released for the duration of your studies

Level of Study: Postgraduate

Type: Scholarship

Value: $\mathrm{R} \$ 500$

Length of Study: 4 year

Frequency: Annual

Country of Study: South Africa

Application Procedure: Apply online: www.agci.gob.cl

Closing Date: 31 October

Funding: Foundation

For further information contact:

Email: becasmandela@gmail.com

\section{China Scholarship Council}

Level 13, Building A3 No.9 Chegongzhuang Avenue, 100044, Beijing, China.

Tel: $\quad$ (86) 66093900

Email: webmaster@csc.edu.cn

Website: www.csc.edu.cn

The China Scholarship council (CSC) is a non-profit institution, which is affiliated with the ministry of education. The main objective of the CSC is to develop the educational, scientific and technological, and cultural exchanges and economic and trade cooperation between China and other countries.

\section{K C Wong Postgraduate Scholarship Programme}

Purpose: To support students who intend to study further at King's College London

Eligibility: Open to applicants who are citizens and permanent residents of People's Republic of china

Type: Scholarship

Value: Tuition fees at the international rate plus an annual stipend of $£ 8,400$

Length of Study: 3 years

Frequency: Annual

Study Establishment: King's College London

Country of Study: United Kingdom

Application Procedure: A completed application form, which is available online, must be sent 
Closing Date: 1 February

Funding: Government

Contributor: K C Wong Education Foundation

\section{For further information contact:}

Research \& Graduate School Support Section King's College London, London WC2R 2LS, United Kingdom.

Tel: $\quad$ (44) 2078483376

Fax: (44) 2078483328

Email: graduateschool@kcl.ac.uk

\section{Chinese American Medical Society (CAMS)}

41 Elizabeth Street, Suite 600, New York, NY 10013, United States of America.

Tel: $\quad$ (1) 2123344760

Email:_jlove@camsociety.org

Website: www.camsociety.org

Contact: Dr H H Wang, Executive Director

The Chinese American Medical Society (CAMS) is a non-profit, charitable, educational and scientific society that aims to promote the scientific association of medical professionals of Chinese descent. It also aims to advance medical knowledge and scientific research with emphasis on aspects unique to the Chinese and to promote the health status of Chinese Americans. The Society makes scholarships available to medical dental students and provides summer fellowships for students conducting research in health problems related to the Chinese

\section{Chinese American Medical Society Scholarship Program}

Purpose: In the early 1970's the Chinese American Medical Society went to considerable lengths to provide scholarships to outstanding medical students in need of financial assistance

Eligibility: 1 . Must be a graduate student 2. Must attend a university 3 . Must not be attending high school currently 4. Must study full-time 5. Restricted to students studying Health and Medical Sciences

Level of Study: Graduate, Postgraduate

Type: Programme grant

Value: US $\$ 5,000-U S \$ 20,000$

Frequency: Annual

Country of Study: Any country
Application Procedure: The submission has to be made to the email address scholarship@camsociety.org Email is the preferred method of submission for applications. The committee asks that all applications and supporting materials be sent as a single PDF file and emailed to scholarship@camsociety.org Closing Date: 30 March

Funding: Private

Additional Information: www.petersons.com/scholarship/ chinese-american-medical-society-scholarship-111_150708. aspx

\section{For further information contact:}

Scholarship Committee, 265 Canal Street, Suite 515, New York, NY 10013, United States of America.

Tel: $\quad$ (1) 2123344760

Email: scholarship@camsociety.org

\section{Chinook Regional Career Transitions for Youth}

Room B310, 1701 - 5 Avenue South, Lethbridge, AB T1J 0W4, Canada.

Tel: $\quad$ (1) 4033283996

Email: mvennard@pallisersd.ab.ca

Website: www.careersteps.ca

The Chinook regional career transitions for youth aims to improve the school-to-work transitions for students, promoting lifelong learning and coordinating and implementing career development activities and programming for youth.

\section{Robin Rousseau Memorial Mountain Achievement Scholarship}

Purpose: To bring about awareness of ways to improve safety in the mountains

Eligibility: Applicants must be Alberta residents and active in the mountain community; and plan to study in any recognized Mountain Leadership and Safety program

Level of Study: Professional development

Type: Scholarship

Value: Course fee

Frequency: Annual

Application Procedure: A completed application form must be sent

Closing Date: 30 January

Additional Information: myredkite.com/finaid/robinrousseau-memorial-mountain-achievement-scholarship 


\section{For further information contact:}

Alberta Scholarship Programs Box 28000 Stn Main, Edmonton, AB T5J 4R4, Canada.

Tel: $\quad$ (1) 7804278640

Fax: (1) 7804271288

Email: scholarships@gov.ab.ca

\section{Toyota Earth Day Scholarship Program}

Purpose: To encourage community service

Eligibility: Open to students who have achieved academic excellence and distinguished themselves in environmental community service and extracurricular and volunteer activities

Level of Study: Professional development

Type: Scholarship

Value: $C \$ 5,000$

Frequency: Annual

Application Procedure: Application form available online

Closing Date: 15 February

Additional Information: ustpaul.ca/upload-files/Financial Aid/scholarships/Toyota_Earth_Day_Scholarship_Program $\% 202010$-En.pdf

\section{For further information contact:}

Toyota Earth Day Scholarship Program, III Peter St., Suite 503, Toronto, ON M5V 2H1, Canada.

Email: scholarship@earthday.ca

\section{Choirs Ontario}

Choirs Ontario A-1422 Bayview Avenue, Toronto, ON M4G 3A7, Canada.

Tel: (1) 4169231144

Email: info@choirsontario.org

Website: www.choirsontario.org

Contact: Melva Graham

Choirs Ontario is an arts service organization dedicated to the promotion of choral activities and standards of excellence. Established in 1971 as the Ontario Choral Federation, Choirs Ontario provides services to choirs, conductors, choristers, composers, administrators and educators as well as anyone who enjoys listening to the sound of choral music. Choirs Ontario operates with the financial assistance of the Ministry of Culture, the Ontario Arts Council, the Trillium Foundation, the Toronto Arts Council and numerous foundations, corporations and individual donors.

\section{Ruth Watson Henderson Choral Composition Competition}

Purpose: To award new choral composition

Eligibility: Candidates must be Canadian citizens or landed immigrants who are permanent residents of Ontario

Level of Study: Postgraduate

Type: Prize

Value: $C \$ 1,000$

Country of Study: Any country

Application Procedure: Further information available on the website

Funding: Private

Additional Information: fst.se/ruth-watson-hendersonchoral-composition-competition

\section{Citizens United for Research in Epilepsy}

\section{Taking Flight Award}

Subjects: Medical and Health Sciences

Purpose: This award seeks to promote the careers of young epilepsy investigators to allow them to develop a research focus independent of their mentor(s).

Type: Fellowship

Value: Up to US $\$ 100,000$

Length of Study: 1 year

Frequency: Annual, if funds are available

Country of Study: Any country

Application Procedure: Information at: www.cureepilepsy. org/the-cure-epilepsy-grant-program-and-grant-opportunities/

No. of awards offered: One

Closing Date: Varies by year but usually in March

\section{Citizens United in Research for Epilepsy (CURE)}

\section{Taking Flight Award}

Subjects: Basic mechanisms of epilepsy; Acquired epilepsies; Pediatric epilepsies; SUDEP; Treatment-resistant epilepsies; and Sleep \& epilepsy. 
Purpose: The award seeks to promote the careers of young epilepsy investigators to allow them to develop a research focus independent of their mentor(s).

Eligibility: You must fall into one of the following categories to be eligible for the Taking Flight Award: A senior postdoctoral fellow who has a minimum of 3 years postdoctoral experience; A clinical fellow who is a Neurology Resident in his/her Neurology training and considering Epilepsy Fellowships; Newly appointed faculty within one year of having completed postdoctoral training. International applicants are welcome; you do not have to be a US citizen or working in the US to apply for this award. All materials must be submitted in English.

Type: Award

Value: Requests may be made for up to US $\$ 100,000$ for one year. Funding requests may include salary support for the PI, technical staff and/or collaborators; supplies, animal costs, publication fees etc.; and travel to an epilepsy-related conference if the PI is presenting his/her CURE-funded research. Funds are not to be used to purchase equipment. Indirect costs are not supported.

Length of Study: One year

Country of Study: Any country

Application Procedure: See website for further details.

Closing Date: 21 November

Additional Information: www.cureepilepsy.org/grantsprogram/\#grant_opportunities

\section{The CURE Epilepsy Award}

Subjects: Basic mechanisms of epilepsy; Acquired epilepsies; Pediatric epilepsies; SUDEP; Treatment-resistant epilepsies; and Sleep \& epilepsy.

Purpose: The award reflects CURE's continued focus on scientific advances that have the potential to truly transform the lives of those affected by epilepsy, with prevention and disease modification as critical goals

Eligibility: This award is available to both established and early career investigators. Generally, early career investigators are university faculty at the assistant professor level (or hold an equivalent position in a non-university research organization). Established investigators are university faculty at the associate professor level or above. Researchers who serve on CURE's Scientific Advisory Council are ineligible to apply for or sponsor a grant for the duration of their term. International applicants are welcome. Postdoctoral fellows may not apply for this award. All materials must be submitted in English.

Type: Award

Value: Requests may be made for up to a total of US $\$ 250,000$ paid over 2 years. Funding requests may include salary support for the Principal Investigator (PI), co-PIs, technical staff, supplies, animal costs, publication fees and travel to an epilepsy-related conference if the PI is presenting his/her CURE-funded research. Limited equipment purchases that are required to complete goals will be considered. Indirect costs are not supported.

Length of Study: Two years

Country of Study: Any country

Application Procedure: See website for further details.

Closing Date: 21 November

Additional Information: www.cureepilepsy.org/grantsprogram/\#grant_opportunities

\section{Clara Haskil Competition}

Case Postale 234, 31 rue du Conseil, CH-1800 Vevey, Switzerland.

Tel: $\quad$ (41) 219226704

Email: info@clara-haskil.ch

Website: www.regart.ch/clara-haskil

Contact: Mr Patrick Peikert, Director

The Clara Haskil Competition exists to recognize and help a young pianist whose approach to piano interpretation is of the same spirit that constantly inspired Clara Haskil, and that she illustrated so perfectly.

\section{Clara Haskil International Piano Competition}

Purpose: To recognize and financially help a young pianist Eligibility: Open to pianists of any nationality and either sex who are no more than 27 years of age

Level of Study: Postgraduate

Type: Prize

Value: CHF 25,000

Frequency: Every 2 years

Country of Study: Any country

Application Procedure: Applicants must pay an entry fee of CHF 200

No. of awards offered: Approx. 150

Funding: Corporation, Trusts, International office

Contributor: Fondation Nestlé pour l'Art

No. of awards given last year: 2

No. of applicants last year: Approx. 150

Additional Information: The competition is usually held during the last weeks of August or the beginning of September app.getacceptd.com/clarahaskil 


\section{For further information contact:}

International Piano Competition, Concours Clara Haskil, $\mathrm{CH}-$ 1800 Vevey, Switzerland.

Tel: (41) 219226704

Fax: (41) 219226734

\section{Clare Hall Cambridge}

\section{Clare Hall Research Fellowships in the Arts and Social Sciences}

Purpose: Research Fellowships are primarily intended to provide opportunities for scholars at an early stage of their academic careers to establish and pursue their research in a supportive academic environment

Eligibility: 1. During their tenure, Research Fellows have no college teaching duties other than to pursue their research. They are however members of the College Governing Body and may serve on other College committees. 2. Successful candidates are expected to be graduate students who have recently completed or who are about to complete their PhD 3. There is no restriction on age, sex or previous standing, except that candidates may not already have held a Research Fellowship at a college of either the University of Oxford or the University of Cambridge, and some preference may be given to candidates who are at a fairly early stage of their research career. 4. Research Fellows are required to live in Cambridge during Full Term, but leave may be granted to work away if necessary. Small grants for research expenses may be made available on application to the Senior Tutor

Level of Study: Research

Type: Fellowship

Length of Study: 3 years

Frequency: Annual

Country of Study: Any country

Application Procedure: Applications must be made online using the following link: app.casc.cam.ac.uk/fas_live/clh arts.aspx

Closing Date: 13 March

Funding: Private

Additional Information: www.clarehall.cam.ac.uk/ research-fellows

\section{For further information contact:}

Clare Hall, Herschel Road, Cambridge, CB3 9AL, United Kingdom.

Email: college.registrar@clarehall.cam.ac.uk

\section{Claude Leon Foundation}

P.O. Box 30538, Tokai 7966, South Africa.

Tel: $\quad$ (27) 217870418

Email: postdocadmin@leonfoundation.co.za

Website: www.leonfoundation.co.za

The Claude Leon Foundation is a South African Charitable Trust. resulting from a Bequest by Claude Leon (1884-1972), A prominent Johannesburg businessman. CLF funds a postdoctoral fellowship programme, now in it's 18th Year - It's goal is the building of research capacity in the faculties of Science, Engineering and Medical Sciences at South African Universities via awards to both South African and foreign postdoctoral scientists.

\section{Claude Leon Foundation Postdoctoral Fellowship}

Purpose: To fund postdoctoral research

Eligibility: Open to South African and foreign nationals. Preference will be given to candidates who have received their doctoral degrees in the last 5 years, and to those who are currently underrepresented in South African tertiary institutions Level of Study: Postdoctorate

Value: ZAR 235,000 PA for a 2-year fellowship plus travel grant up to a maximum of ZAR 45,000 to present a paper on poster at an international conference during the 2nd year of fellowship

Length of Study: 2 years on renewal after the first year Frequency: Annual

Study Establishment: South African universities and some institutions.

Country of Study: South Africa

Application Procedure: Applications are not accepted directly from candidates. They must have been offered a postdoctoral position at a tertiary institution. The application should then be sent to the foundation by the institution not by the candidate

No. of awards offered: 400

Closing Date: 31 May

Contributor: The Claude Leon Foundation, South Africa

No. of awards given last year: 58

No. of applicants last year: 400

Additional Information: Applications should be sent to the foundation by the institution at which the candidate has secured a postdoctoral position, not by the candidate www. leonfoundation.co.za/postdoctoral.htm

\section{For further information contact:}

Email: billfrankel@kayacomm.com 


\section{Coimbra Group}

\section{Coimbra Group Scholarship Programme for Young Professors and Researchers from Latin American Universities}

Purpose: It aims to increase cooperation amongst its members by enhancing special academic and cultural ties, and creating channels of information and exchange

Eligibility: To be a national of and currently resident in a Latin American country. Candidates already living and/or studying in Europe will not be considered. 1. To hold a university degree or equivalent. 2. To be linked as a professor or researcher to a Latin American University recognised as such by the authorities of the country. 3. To use the Coimbra Group Office electronic application process. Only one application per candidate will be accepted. 4. To submit online an Acceptance Letter/email from the tutor/ partner with whom the work programme will be undertaken in the host institution. This document is mandatory. 5. To be born on or after 1 January 1979. 6. Previously selected candidates can apply for a second grant, but they will not be prioritised

Level of Study: Graduate

Type: Scholarship

Frequency: Annual

Country of Study: Any country

Application Procedure: Kindly check the website for further information. www.coimbra-group.eu/wp-content/uploads/ CALL-LA-2019-brochure-1.pdf

Closing Date: 31 March

Funding: Private

Additional Information: The Coimbra Group Office will contact all candidates and inform them about the result of their application by the end of May euraxess.ec.europa.eu/ worldwide/brazil/coimbra-group-scholarship-programmeyoung-professors-and-researchers-latin

\section{For further information contact:}

Egmontstraat, 11, rue d'Egmont, B-1000 Brussels, Belgium.

Tel: $\quad$ (32) 25138332

Email: Moleiro@coimbra-group.eu

\section{Coimbra Group Scholarship Programme for Young Researchers from the European Neighbourhood}

Purpose: The main aim of this scholarship programme is to enable scholars to undertake research in which they are engaged in their home institution and to help them to establish academic and research contacts

Eligibility: Applicants must fulfil all the following criteria: 1. Be born before or after 1 January 1984. 2. Be nationals of and current residents in one Of the above-listed countries. 3 . Be current academic staff members of a university or an equivalent higher education institution located in one of the above-listed countries and be of postdoctoral or equivalent status, although some institutions may offer opportunities to doctoral student

Level of Study: Graduate

Type: Programme grant

Frequency: Annual

Country of Study: Any country

Application Procedure: 1. Candidates may apply for one university only. Multiple applications will not be considered valid. 2. Only the universities listed in the table below are taking part in the current edition of the Coimbra Group Scholarship Programme. 3. Applicants will be able to fill in the on-line registration until 31 March midnight (Brussels time) on the Coimbra Group website: www.coimbra-group. eu/activities/scholarships

Closing Date: 31 March

Funding: Private

Additional Information: armacad.info/coimbra-group2019-02-12-coimbra-group-scholarship-programme-2019for-young-researchers-from-the-european-neighbourhoodeurope

\section{For further information contact:}

Email: quici@coimbra-group.eu

\section{Coimbra Group Short Stay Scholarship Programme for Young Researchers}

Purpose: It aims to increase cooperation amongst its members by enhancing special academic and cultural ties, and creating channels of information and exchange

Eligibility: Applicants should be: 1. Born on or after 1 January 1974. 2. Nationals of and current residents in a country in Sub-Saharan Africa. 3. Current staff members of a university or an equivalent higher education institution in Sub-Saharan Africa. 4. Of doctoral/postdoctoral or equivalent status. Eligible countries are all African countries except Algeria, Egypt, Libya, Morocco, and Tunisia applicants from these countries are eligible under the Scholarship Programme for Young Researchers from the European Neighbourhood

Level of Study: Graduate

Type: Scholarship

Frequency: Annual

Country of Study: Any country 
Application Procedure: Online application form is available in the following link. There are two steps of application procedure to be followed. www.coimbra-group.eu/activities/ scholarships

Closing Date: 31 March

Funding: Private

Additional Information: www.coimbra-group.eu/wpcontent/uploads/CALL-Africa-2019-brochure.pdf

For further information contact:

Email: info@coimbra-group.eu

\section{Collegeville Institute for Ecumenical and Cultural Research}

14027 Fruit Farm Road, Box 2000, Collegeville, MN 56321, United States of America.

Tel: $\quad$ (1) 3203633366

Email: staff@collegevilleinstitute.org

Website: www.collegevilleinstitute.org

Contact: Donald Ottenhoff, Executive Director

The Institute for Ecumenical and Cultural Research seeks to discern the meaning of Christian identity and unity in a religiously and culturally diverse nation and world and to communicate that meaning for the mission of the church and the renewal of human community. The Institute is committed to research, study, prayer, reflection and dialogue, in a place shaped by the Benedictine tradition of worship and work.

\section{Bishop Thomas Hoyt Jr Fellowship}

Purpose: To provide the Institute's residency fee to a North American person of colour writing a doctoral dissertation, in order to help the churches to increase the number of persons of colour working in ecumenical and cultural research

Eligibility: Open to a North American, Canadian or Mexican person of colour writing a doctoral dissertation within the general area of the Institute's concern

Level of Study: Postgraduate

Type: Fellowship

Value: US $\$ 5,000$ per year

Length of Study: 1 academic year

Frequency: Annual

Study Establishment: The Institute

Country of Study: United States of America

Application Procedure: Applicants must apply in the usual way to the Resident Scholars Programme (see separate listing). If invited by the admissions committee to be a Resident
Scholar, the person will then be eligible for consideration for the Hoyt Fellowship

No. of awards offered: 1

Closing Date: 1 November

Funding: Private

No. of awards given last year: 1

No. of applicants last year: 1

For further information contact:

Tel: $\quad$ (1) 3203633367

Email: dottenhoff@collegevilleinstitute.org

\section{Columbia College of Missouri}

\section{Columbia College of Missouri Boone County Endowed Award}

Purpose: This award is for Missouri high school seniors who are residents of Boone County and planning to attend Columbia College

Eligibility: Must be a graduating high school senior. Must be a resident of Boone County, MO. 1. Must be a United States citizen or permanent resident. 2. Must demonstrate community service/volunteer work. 3. Must enroll as a full-time student. 4. Must have a cumulative grade point average of 3.1 or higher. 5. Must have an ACT score of 22 or higher or the equivalent SAT score

Level of Study: Graduate

Type: Award

Value: US $\$ 1,000$

Frequency: Annual

Country of Study: United States of America

Application Procedure: The scholarship is made possible through the support of more than 200 area businesses. Recipients of the award will be chosen by committee in April and will be notified appropriately. Application details are available in the form of pdf. www.ccis.edu/offices/financialaid/ booneendowed/boonecountyendowedscholarshipday.pdf

Closing Date: 31 March

Funding: Private

No. of awards given last year: 5

Additional Information: www.unigo.com/scholarships/all/ columbia-college-of-missouri-boone-county-endowed-award/ 1070

\section{For further information contact:}

1001 Rogers St., Columbia, MO 65216, United States of America.

Tel: $\quad$ (1) 5738757506

Email: admissions@ccis.edu 


\section{Columbia GSAS}

\section{Foreign Language and Area Studies Fellowship}

Purpose: Administered by the Title VI National Resource Centers at the University of Pennsylvania, the Foreign Language and Area Studies (FLAS) Fellowships program funding to Graduate and Undergraduate Students studying modern foreign languages and related area studies

Eligibility: Students receiving Academic Year Fellowships must be enrolled in full-time study for the duration of the FLAS award and must take one language course and one related area or international studies course each semester. 1. Fellows must be United States Citizens or permanent residents. 2. Academic Year Fellows must be admitted to or enrolled in undergraduate, graduate, or professional programs at the University of Pennsylvania. FLAS awards may be used in some cases for students participating in official overseas language programs and in very limited cases for dissertators Level of Study: Postgraduate

Type: Fellowship

Value: US $\$ 5,000$ and a US\$2,500

Frequency: Annual

Country of Study: Any country

Application Procedure: You will need to create a free online Interfolio account and complete the application in that system. In addition to entering information into the account, you will need to upload: 1. A personal statement regarding your planned use of the FLAS fellowship. This is a one-page, single-spaced, essay describing why this language study is essential to realizing your study and career goals. 2. Your curriculum vitae. 3 . Unofficial higher education transcript (s) of your most recent academic work, whether at the University of Pennsylvania or another university or college, in digital format. Transcripts may be verified during the review process. 4. Two letters of recommendation (you will request them through the system). When you ask the faculty members for a recommendation, tell them that all letters of recommendation must specifically address how a FLAS would contribute to your current program of study or would be integrated with it

Closing Date: 13 February

Funding: Private

Additional Information: gsas.columbia.edu/student-guide/ financing-your-education/flas-fellowship-summer

\section{For further information contact:}

Graduate School of Arts and Sciences, 107 Low Memorial Library, 535 West 116th Street, New York, NY 10027, United States of America.

Email: gsas-fellowships@columbia.edu

\section{Graduate School of Arts and Sciences International Travel Fellowships}

Purpose: Travel Fellowships provide funding for international travel (outside of the United States) that is necessary for the completion of the dissertation. Travel Fellowship funds may not be used for research in residence at Columbia

Eligibility: 1. Be a PhD student in an Arts and Sciences program 2. Have completed all requirements for the MPhil degree and passed the prospectus defense before September 1 Level of Study: Graduate

Type: Fellowships, operating grants

Frequency: Annual

Country of Study: Any country

Application Procedure: Applications must include the following items: 1. Completed GSAS online application form. 2. An up-to-date GSAS transcript (official PDF transcript from the Registrar's office). Note: The GSAS Fellowship application does not accept encrypted files for upload. Official Columbia transcript PDFs are encrypted; you may order a paper copy through SSOL or print the official transcript PDF you receive from Parchment, then scan and upload it. 3. A curriculum vitae (three pages maximum). 4. A statement of your language preparation for research abroad, specifying the language(s) needed to carry out your research and your proficiency in each (one page maximum). 5. A project proposal of no more than 1,500 words, which should include a justification of your need to travel and a specific discussion of your research plans during the fellowship period. Please do not submit a copy of the departmental dissertation prospectus. Proposals will be read by an inter-departmental faculty committee and should emphasize the potential of your research to make a contribution to the particular field and to scholarship in general. 6. A timetable for completion of research and writing (two pages maximum). Please be as specific as possible. Applicants can apply for only one of the following terms: academic year (fall and spring). 7. Two letters of recommendation. GSAS prefers that recommenders submit their letters of recommendation electronically to expedite processing. 8. A budget proposal

Closing Date: 26 February

Funding: Private

Additional Information: The terms of the GSAS Travel Fellowship prohibit grantees from holding teaching assignments or any other position concurrently gsas.columbia.edu/ student-guide/dissertation/gsas-international-travel-awards

\section{For further information contact:}

109 Low Memorial Library, MC 4306, 535 West 116th Street, New York, NY 10027, United States of America.

Email: gsas-admissions@columbia.edu 


\section{Columbia University}

405 Low Library, MC 4335, 535 West 116th Street, New York, NY 10027, United States of America.

Tel: $\quad$ (1) 2128543830

Email:_support@ei.columbia.edu

Website: www.earth.columbia.edu

The Earth Institute at Columbia University brings together talent from throughout the University to address complex issues facing the planet and its inhabitants, with particular focus on sustainable development and the needs of the world's poor.

\section{Benjamin A. Gilman International Scholarship Program}

Purpose: The United States Department of State's Benjamin A. Gilman International Scholarship is a grant program that enables students of limited financial means to study or intern abroad, thereby gaining skills critical to our national security and economic competitiveness

Eligibility: Gilman Scholarships are open to undergraduates in good academic standing at accredited United States colleges and universities who are United States citizens and who meet the following criteria: 1 . They are receiving a federal Pell Grant or can provide proof that they will be receiving a Pell Grant at the time of application of during their term of study abroad. 2. They are applying to or have been accepted into a study abroad program eligible for credit at their home institution. 3. They are studying abroad for at least four consecutive weeks in one country. 4. They are studying abroad in any country except a country on the United States Department of State's current Travel Warning list

Level of Study: Postgraduate

Type: Scholarship

Value: Awards of up to US\$5,000 for semester or academic year program

Frequency: Annual

Country of Study: Any country

Closing Date: 3 March

Funding: Private

Additional Information: urf.columbia.edu/fellowship/ benjamin-gilman-international-scholarships

\section{For further information contact:}

202 Hamilton Hall, MC 2811, 1130 Amsterdam Ave, New York, NY 10027, United States of America.
Tel: (1) 2128532375

Fax: (1) 2128542797

Email: ugrad-urf@columbia.edu

\section{Knight-Bagehot Fellowships in Economics and Business Journalism at Columbia University}

Purpose: To improve the quality of economics and business journalism through instruction to mid career journalists.

Eligibility: Open to professional journalists globally;

Level of Study: Graduate, Postgraduate, MBA

Type: Fellowship

Value: An approximately US $\$ 60,000$ stipend to cover living expenses, plus tuition for the full academic year at Columbia University

Length of Study: 1 academic year

Frequency: Annual

Study Establishment: School of Journalism, Columbia University

Country of Study: United States of America

Application Procedure: Applicants must submit a completed application form, two 1,000 word essays, three letters of reference, and five work samples. journalism.colum bia.edu/kb

No. of awards offered: 10 Fellows each year

Closing Date: 31 January

Funding: Corporation, Foundation, Trusts

Contributor: Knight Foundation

No. of awards given last year: 10

No. of applicants last year: 100

Additional Information: journalism.columbia.edu/ $\mathrm{kb}$

\section{For further information contact:}

Graduate School of Journalism, Columbia University, 2950 Broadway, New York, NY 10027, United States of America.

Tel: $\quad$ (1) 2128542711

Fax: (1) 2128547837

Email: ann.grimes@columbia.edu

\section{Marie Tharp Visiting Fellowships}

Purpose: To provide an opportunity for women scientists to conduct research at one of the related departments within the Earth Institute

Eligibility: Open to women candidates who have obtained their $\mathrm{PhD}$ and are citizens of the United States

Level of Study: Doctorate, Research

Type: Fellowships

Value: US $\$ 25,000$ 
Length of Study: 3 months

Frequency: Annual

Country of Study: United States of America

Application Procedure: Applicants must submit a 3-page proposal, a curriculum vitae, a proposed budget and complete contact information of 3 references

Additional Information: All application materials may be submitted by mail or by email www.earth.columbia.edu/ sitefiles/file/Research/Marie_Tharp_Information_Packet.pdf

\section{For further information contact:}

ADVANCE at The Earth Institute at Columbia University Lamont-Doherty Earth Observatory of Columbia University, 61 Rte 9W, Palisades, NY 10964, United States of America.

Email: kdutt@1deo.columbia.edu

\section{Commonwealth Eye Health Consortium}

International Centre for Eye Health, London School of Hygiene \& Tropical Medicine, Keppel Street, London, WC1E 7HT, United Kingdom.

Tel: (44) 2076368636

Email:_press@1shtm.ac.uk

Contact: Commonwealth Eye Health Consortium

The Commonwealth Eye Health Consortium is a group of expert organizations working together to deliver a five-year programme of fellowships, research, and technology to strengthen eye health systems across the Commonwealth.

\section{CEHC Masters Scholarships in Public Health for Eye Care}

Purpose: The Masters in Public Health for Eye Care at the London School of Hygiene \& Tropical Medicine is a wellestablished course that aims to train leaders in the prevention of blindness and to strengthen research and academic capacity for eye care programmes and training facilities, particularly in low- and middle-income countries

Eligibility: See the website. Entrance Requirement : 1. Come from low or middle-income Commonwealth countries that are less represented in the alumni body of the MSc Public health for eye care. 2. Work in regions where there are severe constraints in human resources for eye health work in regions where there are no / limited training opportunities in
PHEC / community eye health. 3. Demonstrate previous involvement/commitment to community eye health activities or VISION2020 programmes Present a clear career plan in public health for eye care, which they will realistically. 4 . Be able to follow on completion of the MSc. 5. Have experience in public health for eye care based research and/or training in eye care. 6. Fulfill the United Kingdom Border Agency English Language Requirement by passing the LSHTM English language requirement by 11 May

Value: Several scholarships are awarded each year. Each scholarship covers the following:All course feesTwo return flightsDissertation project fundLiving costsAccommodation with food at the International Students House in Central London. Find out more about the International Students House

Study Establishment: Scholarships are awarded to undertake MSc in Public Health for Eye Care

Country of Study: United Kingdom

Application Procedure: Apply to the London School of Hygiene \& Tropical Medicine for a place on the course: if you have applied and been accepted to the academic year you must request to "be reconsidered" for the academic year. Please contact the LSHTM Registry to be asked to "be reconsidered" Once you have received an offer from the London School of Hygiene \& Tropical Medicine here: CEHC; MSc Scholarships Application

Closing Date: 11 May

Additional Information: For more details please browse the website scholarship-positions.com/cehc-masters-scholarshipsin-public-health-eye-care-uk/ iceh.lshtm.ac.uk/commonwealtheye-health-consortium-cehc-scholarships-2018-19-for-mscpublic-health-for-eye-care/

\section{For further information contact:}

Email: Romulo.Fabunan@Lshtm.ac.uk

\section{Commonwealth Fund}

1 East 75th Street, New York, NY 10027, United States of America.

Tel: $\quad$ (1) 2126063800

Email: grants@cmwf.org

Website: www.cmwf.org

The Commonwealth Fund of New York is a philanthropic foundation established in 1918. The Fund supports independent research on health and social issues and makes grants to improve healthcare practice and policy. 


\section{Australian-American Health Policy Fellowship}

Purpose: To enable Fellows to gain an in-depth understanding of the Australian health care system and policy process, recent reforms, and models for best practice, thus enhancing their ability to make innovative contributions to policymaking in the United States, to improve the theory and practice of health policy in Australia and the United States by stimulating the cross-fertilization of ideas and experience and to encourage ongoing health policy collaboration and exchange between Australia and the United States by creating a network of international health policy experts

Eligibility: Open to accomplished, mid-career health policy researchers and practitioners including academics, physicians, decision makers in managed care and other private organizations, federal and state health officials and journalists Level of Study: Research

Type: Fellowship

Value: For a full 10-month stay in Australia, the fellowship awards up to AU $\$ 87,000$ which includes a living allowance, relocation expenses, research related travel and conferences, etc. There is also a family supplement available (e.g. up to AU $\$ 26,000$ for a partner and two children). Round trip airfares to Australia are also covered

Length of Study: Up to 10 months

Frequency: Annual

Study Establishment: Suitable establishment in Australia Country of Study: Australia

Application Procedure: Please go to www. commonwealthfund.org/grants-and-fellowships/fellowships/ australian-american-health-policy-fellowship/applicationform to know complete procedure to apply for this program

Closing Date: 2 October

Funding: Government

Additional Information: In Australia: Director; International Strategies Branch Portfolio Strategies Division Department of Health and Ageing MDP 85, GPO Box 9848, Canberra ACT 2601, Australia; Tel: (61) 26289 4593; Fax: (61) 26289 7087. Australian-American Health Policy Fellowships is the successor of the Packer Policy Fellowship Program, which ran from 2003 to 2009. Email at packerpoli cyfellowship@health.gov.au www.commonwealthfund.org/ publications/newsletter-article/australian-american-healthpolicy-fellow ship-0

\section{For further information contact:}

Email: ro@cmwf.org

\section{Harkness Fellowships in Health Care Policy}

Purpose: To build a network of policy orientated health care researchers whose multinational experience and outlook stimulate innovative policies and practices in the United States and other industrialised countries

Eligibility: Open to Australian, British, and New Zealand citizens. Applicants must be at postgraduate level or have equivalent experience

Level of Study: Postgraduate

Type: Fellowship

Value: Up to US\$75,000

Length of Study: 4 months-1 year

Frequency: Annual

Study Establishment: A host institution which is normally, but not exclusively, of an intellectual kind, such as a university graduate school, a research institute or a 'think tank'

Country of Study: United States of America

Application Procedure: Applicants must write for details

Additional Information: www.commonwealthfund.org/fel lowships/harkness-fellowships-health-care-policy-and-practice Applicants must be submitted via email

\section{For further information contact:}

Harkness Fellowship in Health Care, Associate Professor \& Directo, Center for Health Economics Research \& Evaluation, University of Sydney, Mallett Street Campus, 88 Mallett Street Level 6 Building F, Camperdown, NSW 2050, Australia.

Tel: $\quad$ (61) 293510900

Fax: (61) 293510930

Email: mf@cmwf.org

\section{Harkness Fellowships in Healthcare Policy and Practice}

Purpose: To encourage the professional development of promising healthcare policy researchers and practitioners who will contribute to innovation in healthcare policy and practice in the United States of America and their home countries

Eligibility: Open to individuals who have completed a Master's degree or $\mathrm{PhD}$ in health services or health policy research. Applicants must also have shown significant promise as a policy-orientated researcher or practitioner, e.g. physicians or health service managers, journalists and government officials, with a strong interest in policy issues. Candidates should also be at the research Fellow to senior lecturer level, if academically based; be in their late 20 s to early $40 \mathrm{~s}$, and have been nominated by their department chair or the director of their institution

Level of Study: Postgraduate, Professional development, Research

Type: Fellowship 
Value: up to US\$130,000 in support, with an additional family supplement (up to US\$60,000 for a partner and two children up to age 18)

Length of Study: spend up to 12 months in the United States

Frequency: Annual

Study Establishment: An academic or other research policy institution

Country of Study: United States of America

Application Procedure: Applicants must complete a formal application available online at the website www.cmwf.org/ fellowships

Funding: Private

Contributor: The Commonwealth Fund

Additional Information: www.commonwealthfund.org/fel lowships/harkness-fellowships-health-care-policy-and-practice

\section{For further information contact:}

Email: mf@cmwf.org

\section{The Commonwealth Fund Mongan Fellowship in Minority Health Policy}

Purpose: To create physician-leaders who will pursue careers in minority health policy

Eligibility: Open to physicians who are citizens of the United States of America and who have completed their residency. Additional experience beyond residency is preferred. Applicants must demonstrate an awareness of, or interest and experience in dealing, with the health needs of minority populations, strong evidence of past leadership experience, as related to community efforts and health policy and the intention to pursue a career in public health practice, policy, or academia

Level of Study: Graduate, Postgraduate, Professional development, Research

Type: Fellowship

Value: US\$60,000 stipend, full tuition, health insurance, books, travel, and related program expenses, including financial assistance for a practicum project

Length of Study: five one-year, degree-granting

Frequency: Annual

Study Establishment: Harvard Medical School

Country of Study: United States of America

Application Procedure: Applications available online at the website: www.cmwf.org/fellowships

Closing Date: 2 December

Funding: Foundation

Additional Information: For more information, please visit: mfdp.med.harvard.edu/cff/how-apply www.commonwealth fund.org/commonwealth-fund-fellowship-minority-healthpolicy-harvard-university

\section{For further information contact:}

Minority Faculty Development Program, Harvard Medical School, 164 Longwood Avenue, 2nd Floor, West Court, Boston, MA 02115, United States of America.

Tel: $\quad$ (1) 6174322922

Fax: (1) 6174323834

Email: mfdp_cfhuf@hms.harvard.edu

\section{Commonwealth Scholarship and Fellowship Plan}

Commonwealth Scholarship Commission in the United Kingdom, c/o Association of Commonwealth Universities, John Foster House, 36 Gordon Square, London, WC1H OPF, United Kingdom.

The Plan was drawn up at the first Commonwealth Education Conference held in Oxford in 1959. It is a system of awards for men and women from all Commonwealth countries to study in countries other than their own. One of its guiding principles is that it be based on mutual co-operation

\section{Commonwealth Shared Scholarship Scheme at United Kingdom Universities}

Purpose: Commonwealth Shared Scholarships are for candidates from least developed and lower middle income Commonwealth countries, for full-time Master's study on selected courses, jointly supported by United Kingdom universities. The scholarships do not cover undergraduate courses, PhD study, or any pre-sessional English language teaching

Eligibility: 1 . Be a citizen of or have been granted refugee status by an eligible Commonwealth country, or be a British Protected Person. 2. Be permanently resident in a developing Commonwealth country. 3. Be available to start your academic studies in the United Kingdom by the start of the United Kingdom academic year in September/October. 4. By October, hold a first degree of at least upper second class $(2: 1)$ standard, or a second class degree and a relevant postgraduate qualification (usually a Master's degree). 5. Not have studied or worked for one (academic) year or more in a developed country. 6 . Be unable to afford to study in the United Kingdom without this scholarship

Level of Study: Postdoctorate

Type: Scholarship

Value: $£ 1,330$

Length of Study: 1 year 
Frequency: Annual

Country of Study: Any country

Application Procedure: Apply online

Closing Date: 14 March

Funding: Foundation

Additional Information: cscuk.dfid.gov.uk/apply/sharedscholarships/

\section{For further information contact:}

Woburn House, 20-24 Tavistock Square, London, WC1H 9HF, United Kingdom.

\section{Commonwealth Scholarship Commission in the United Kingdom}

The Association of Commonwealth Universities, Woburn House, 20;24 Tavistock Square, London, WC1H 9HF, United Kingdom.

Tel: $\quad$ (44) 2073806700

Email: info@cscuk.org.uk

Website: www.dfid.gov.uk/cscuk

Contact: Ms Natasha Lokhun, Communications Officer

The Commonwealth Scholarship Commission (CSC) in the United Kingdom is responsible for managing Britain's contribution to the Commonwealth Scholarship and Fellowship Plan (CSFP). The CSC makes available seven types of award and supports around 700 awards in total annually.

\section{Association of Commonwealth Universities Titular Fellowships}

Purpose: To enable the universities of the commonwealth to develop the human resources of their institutions and countries through the interchanging of people, knowledge, skills and technologies. Not intended for degree courses, or for immediately postdoctoral programmes

Eligibility: Applicants must be on the staff of member universities under the ACU, the Commonwealth interuniversity organization or working in industry, commerce or public service in a Commonwealth country. Applicant must be within 28-50 years of age

Level of Study: Professional development

Type: Scholarship
Value: $£ 5,000$ for travel, board, insurance and fees where the approved programme includes a training programme

Length of Study: 6 months

Frequency: Annual

Study Establishment: ACU member university or in industry, commerce or public sector

Country of Study: Commonwealth countries

Application Procedure: Candidates must be nominated by executive heads of ACU member universities or by the chief executive officer of a Commonwealth interuniversity organization. Full application details on ACU website

No. of awards offered: 50

Closing Date: 30 April

Contributor: ACU

No. of awards given last year: 8

No. of applicants last year: 50

For further information contact:

Email: acuawards@acu.ac.uk

\section{Community Foundation for Calderdale}

Office 158, Dean Clough, Halifax, Yorkshire, HX3 5AX, United Kingdom.

Tel:

(44) 1422349700

Email: enquiries@ccfound.co.uk

Website: www.ccfund.co.uk

Contact: Mr Mohammad Aslam, Director of the Board, Grants

\section{W.D. Farr Endowment Fund Grants}

Purpose: The Greeley Rotary W. D. Farr Endowment Fund at the Community Foundation Serving Greeley and Weld County welcomes applications and considers grant requests from US\$500 to US\$2,500 for the benefit of the youth of Greeley, Colorado. The W.D. Farr Endowment Fund supports programs in the Greeley area that enhance

Level of Study: Graduate

Type: Grant

Value: US $\$ 500$ to US $\$ 2,500$

Frequency: Annual

Country of Study: Any country

Application Procedure: Attachment Checklist requires following information to process further proposal. 1. Cover letter. 2. Project budget sheet. 3. Board of Directors list 
Closing Date: 31 January

Funding: Private

\section{For further information contact:}

2425 35th Avenue, Suite 201, Greeley, CO 80634, United States of America.

Email: info@cfsgwc.org

\section{Concordia University}

1455 De Maisonneuve Blvd. W., QC H3G 1M8, Montréal, Canada.

Tel: $\quad$ (1) 5148482424

Website: www.concordia.ca

Contact: Ms Patricia Verret, Graduate Awards Manager

Concordia University is the result of the 1974 merger between Sir George Williams University and Loyola College. The University incorporates superior teaching methods with an interdisciplinary approach to learning and is dedicated to offering the best possible scholarship to the student body and to promoting research beneficial to society

\section{Bank of Montréal Pauline Varnier Fellowship}

Purpose: To support graduate students to acquire higher degree in the fields of business and commerce

Eligibility: Open to women with 2 years of cumulative business experience who are entering full-time studies in the MBA program at the John Molson School of Business. Candidates must be Canadian citizens or permanent residents

Level of Study: MBA

Type: Fellowship

Value: $C \$ 10,000$ per year

Length of Study: 2 years

Frequency: Annual

Study Establishment: Concordia University

Country of Study: Canada

Application Procedure: Applicants must submit a completed application form, three letters of recommendation and official transcripts of all university studies by the closing date

Closing Date: 1 February
Funding: Private

No. of awards given last year: 1

Additional Information: Academic merit is the prime consideration in the granting of the awards

\section{For further information contact:}

M.B.A. Program, Faculty of Commerce and Administration, Concordia University, 1455 Boulevard de Maisonneuve O, Montréal, QC H3G 1M8, Canada.

Tel: $\quad$ (1) 8482424 ext 2717

Email: gradprograms@jmsb.concordia.ca

\section{Congressional Black Caucas Foundation}

\section{Congressional Black Caucus Foundation Spouses Visual Arts Scholarship}

Purpose: This award is for students with majors in the visual arts including, but not limited to, architecture, ceramics, drawing, fashion, graphic design, illustration, interior design, painting, photography, sketching, video production and other decorative arts

Eligibility: 1. Must be a full-time student. 2. Must be planning to pursue a degree in a field that will lead to a career in the visual arts. The visual arts include architecture, ceramics, drawing, fashion, graphic design, illustration, interior design, painting, photography, sketching, video production and other visual arts. Must have minimum GPA of 2.5 on a 4.0 scale. This award is for United States students

Level of Study: Postgraduate

Type: Scholarship

Value: US $\$ 3,000$

Frequency: Annual

Country of Study: United States of America

Application Procedure: 1. The online application is available on the Congressional Black Caucus Foundations (CBC) website. During the online application process, the applicant must upload and/or complete the following forms. 2. A personal statement essay from the student (500-1,000 words) that addresses all four (4) of the topics listed on the application in one cohesive essay. 3. Two (2) letters of recommendation (Email addresses will be requested of each recommender for electronic submission of the letter. Hard copy letters will not be accepted.)

Closing Date: 31 March

Funding: Private 
Additional Information: Late applications and materials will not be accepted www.petersons.com/scholarship/cbcspouses-visual-arts-scholarship-111_182500.aspx

\section{For further information contact:}

1720 Massachusetts Avenue NW, Washington, DC 20036, United States of America.

Tel: $\quad$ (1) 2022632800

Email: scholarships@cbcfinc.org

\section{Conseil Européen Pour la Recherche Nucléaire European Organization for Nuclear Research}

CH-1211 Geneva 23, Switzerland.

Tel: $\quad$ (41) 227678484

Email: recruitment.service@cern.ch

Website: www.cern.ch

CERN European Laboratory for Particle Physics is the world's leading laboratory in its field, that being the study of the smallest constituents of matter and of the forces that hold them together. The laboratory's tools are its particle accelerators and detectors, which are among the largest and most complex scientific instruments ever built

\section{Conseil Européen Pour la Recherche Nucléaire Summer Student Programme}

Purpose: To awaken the interest of undergraduates in CERN's activities by offering them hands-on experience during their long summer vacation

Eligibility: 1. You are a Bachelor or Master student (not PhD) in the Fields of Physics, Engineering, Computer Science or Mathematics. 2. Should have completed, at least Three Years of Full-Time Studies at University Level. 3. You have a good knowledge of English (However, IELTS or TOEFL is Not Required). 4. Candidates of all nationalities are welcome to apply for this Summer Student Programme.

Value: A 90 CHF Per Day Allowance to Cover the Cost of Accommodation \& Meals for a single person and A Round Airfare Tickets Travel Allowance to \& From Geneva.

Length of Study: 8-13 weeks

Study Establishment: CERN

Country of Study: Switzerland

Application Procedure: You need to apply online
Closing Date: 31 January

Additional Information: Please check at home.web.cern.ch/ students-educators/summer-student-programme opportuni tiescorners.info/cern-summer-student-program-2020/

For further information contact:

Email: jkrich@umich.edu

\section{Conseil Européen Pour la Recherche Nucléaire- Japan Fellowship Programme}

Purpose: To support young researchers who are interested in LHC data analysis and physics studies

Eligibility: Applicants should be nationals or permanent residents of Japan and have a doctorate for applicants in experimental or phenomenological physics and/or accelerator science. Candidates who are currently preparing a $\mathrm{PhD}$ are eligible to apply. However, they are expected to have obtained their PhD by the time they take up their appointment at CERN

Level of Study: Doctorate

Type: Fellowship

Value: Covers travel expense and insurance coverage

Length of Study: Up to 3 years

Frequency: Annual

Application Procedure: A completed electronic application form along with a curriculum vitae should be submitted

Closing Date: 1 December

Contributor: CERN

Additional Information: Please check at jobs.web.cern.ch/ job/10941

\section{For further information contact:}

Email: recruitment.science@cern.ch

\section{Marie Curie Fellowships for Early Stage Training at CERN}

Purpose: To offer structured scientific and/or technological training and to encourage participants to take up long-term research careers

Eligibility: Open to researchers in the first 4 years of their research activity. Persons who have obtained a doctorate are ineligible

Study Establishment: CERN

Application Procedure: Candidates should register and apply for the Marie Curie Fellowship programme using the CERN e-recruitment system

Contributor: European Comission 


\section{Conservation Leadership Programme}

Conservation Leadership Programme, Birdlife International, Wellbrook Court, Girton Road, Cambridge, CB3 0NA, United Kingdom.

Tel: $\quad$ (44) 1223277318

Email: clp@birdlife.org

Website: www.conservationleadershipprogramme.org

Contact: The Programme Manager

Since 1985, the Conservation Leadership Programme has supported and encouraged international conservation projects that address global conservation priorities at a local level. This is achieved through a comprehensive system of advice, training and awards. The programme is managed through a partnership between BP, FFI, CI, WCS and Birdlife International.

\section{Future Conservationist Awards}

Purpose: To develop leadership capacity amongst emerging conservationists to address the most pressing conservation issues of our time

Eligibility: The project must address a globally recognized conservation priority, involve people, have host government approval, be run by teams of at least three people, be studentled, have over $50 \%$ students registered, last for less than 1 year and take place in Africa, Asia Pacific, Middle East, Eastern Europe, Latin America or the Caribbean

Level of Study: Doctorate, Graduate, Postgraduate

Type: Award

Value: Up to US\$12,500

Length of Study: Projects should be less than 1 year in length Frequency: Annual

Country of Study: This is a global programme

Application Procedure: Application forms are available from the website. Applications should be made electronically No. of awards offered: 360

Funding: Private

Contributor: BP, BirdLife International, Conservation International, WildLife Conservation Society, and Fauna and Flora International

No. of awards given last year: 29

No. of applicants last year: 360

Additional Information: Please be sure to check at www. conservationleadershipprogramme.org/FutureConservatio nistAward.asp www.conservationleadershipprogramme.org/ grants/grant-overview/future-conservationist-award/

\section{Conservation Trust}

National Geographic Society, 1145 17th Street NW, Washington, DC 20036-4688, United States of America.

Email:_conservationtrust@ngs.org

Website: www.nationalgeographic.com/conservation

The objective of the Conservation Trust is to support conservation activities around the world as they fit within the mission of the National Geographic Society. The trust will fund projects that contribute significantly to the preservation and sustainable use of the Earth's biological, cultural, and historical resources.

\section{National Geographic Conservation Trust Grant}

Purpose: To support cutting programmes that contribute to the preservation and sustainable use of the Earth's resources Eligibility: Applicants must provide a record of prior research or conservation action. Researchers planning work in foreign countries should include at least one local collaboration as part of their research teams. Grants recipients are excepted to provide the National Geographic Society with rights of first refusal for popular publication of their findings

Level of Study: Research

Type: Research grant

Value: US\$15,000-20,000

Frequency: Annual

Application Procedure: Apply online at www.national geographic.com/explorers/grants-programs/conservationtrust-application

Funding: Trusts

Contributor: National Geographic Society

\section{For further information contact:}

Conservation Trust, National Geographic Society, 1145 17th Street NW, Washington, DC 20036, United States of America.

\section{Consortium for Advanced Research Training in Africa (CARTA)}

Consortium for Advanced Research Training in Africa (CARTA), Nairobi, KE, Kenya.

Tel: (254) 204001000

Email: carta@aphrc.org

Website: www.cartafrica.org/ 
CARTA's mission is to promote the health and development of African populations through high-quality research on policy-relevant priority issues. The initiative will foster the emergence of vibrant and viable multidisciplinary research hubs of locally-trained internationally recognized scholars.

\section{Consortium for Advanced Research Training in Africa PhD Fellowships}

Purpose: CARTA offers an innovative model for doctoral training in sub-Saharan Africa to strengthen the capacity of participating institutions to conduct and lead internationallycompetitive research

Eligibility: A Masters degree in a relevant field, Prior admission into a $\mathrm{PhD}$ program is not required for application but awards are contingent on such admission being obtained at one of the participating African universities, Male applicants must be under the age of 40 years and female applicants under the age 45 years

Level of Study: Postgraduate

Type: Fellowship

Value: Fellowships cover tuition fees, medical insurance and other university fees in special circumstances only

Length of Study: The fellowship runs for a maximum of 4 years

Country of Study: Africa

Closing Date: 30 April

Funding: International office

Additional Information: Please check website for more details www.opportunitiesforafricans.com/carta-phd-fellow ships-2019-2020/

For further information contact:

Email: carta_fellowship@aphrc.org

\section{Consortium for Applied Research on International Migration}

PO Box 616, NL-6200 MD, Maastricht, Netherlands.

Email: secretariaat-carim@maaastrichtuniversity.nl

CARIM is one of the top institutes for translational cardiovascular research in Europe. It is among the world leaders in the fields of research into vascular and thrombotic disorders and atrial fibrillation as well as translational heart failure research. It has also made important international contributions to molecular imaging in the cardiovascular field.

\section{Consortium for Applied Research on International Migration Postdoctoral Talent Fellowship}

Purpose: Purpose is to provide recently promoted top CARIM talent a chance to gain experience abroad and return to CARIM to perform excellent research

Eligibility: For eligibility details, please visit the website

Level of Study: Postdoctoral

Type: Fellowship

Value: The fellowship amounts to $€ 53,011$ gross which is meant for a period of 12 months. Bench fees are not included in this fellowship. The fellowship includes one return flight to the host institute (based on economy fare)

Country of Study: Any country

Application Procedure: There will be one call a year, and the deadline for the "CARIM - Postdoctoral Talent Fellowship" is the 13th of May, 00.00 hours. To apply for the "CARIM Postdoctoral Talent Fellowship", the applicants from within (or connected to) CARIM are invited to submit an application (by mail) to the CARIM office (secretariaat-carim-atmaastrichtuniversity.nl)

Closing Date: 30 May

Additional Information: www.nationalmeritscholarships. $\mathrm{com} /$ carim-postdoctoral-talent-fellowship.html

For further information contact:

Email: secretariaat-carim@maastrichtuniversity.nl

\section{Cooperative Research Centre for Water Quality and Treatment (CRCWQT)}

Australia Water Quality Centre, Private Mail Bag 3, Salisbury, SA 5108, Australia.

Tel: $\quad$ (61) 882590326

Email:_dennis.steffensen@sawater.com.au

Website: www.waterquality.crc.org.au

Contact: Professor Dennis Mulcahy, Training Leader

The Cooperative Research Centre for Water Quality and Treatment (CRCWQT) provides a national strategic research capacity for the Australian water industry and focuses on issues relating to water quality management and health risk reduction. 


\section{Cooperative Research Center for Water Quality and Treatment Young Water Scientist of the Year Scholarship}

Purpose: To provide support to $\mathrm{PhD}$ students for research done within the Water Forum CRC

Eligibility: Open to candidates who are in the final year of their $\mathrm{PhD}$.

Level of Study: Doctorate

Type: Scholarship

Value: AU $\$ 2,500$

Length of Study: 1 year

Frequency: Annual

Country of Study: Australia

For further information contact:

Email: detr@wmo.int

\section{Copenhagen Business School}

Solbjerg Plads 3, DK-2000 Frederiksberg, Denmark.

Tel: $\quad$ (45) 38153815

Email:_cbs@cbs.dk

Website: www.cbs.dk

\section{Copenhagen Business School PhD Scholarship on IT Management}

Eligibility: To be considered, the candidate should have a basic training at the Masters level (similar to the $3+$ 2 Bologna process). An educational background in the social sciences is necessary. The applicant must have successfully completed the Masters degree before commencing PhD at CBS. The applicants must be fluent in English

Level of Study: Doctorate, Research

Type: Scholarship

Value: The scholarships are fully salaried positions, according to the national Danish collective agreement. The scholarship includes the tuition fees, office space, travel grants, plus a salary, currently starting with per month approx. DKK 23,770 (approx. €3,160) up to DKK 28,964 (approx. $€ 3,860$ ) depending on seniority, plus a pension contribution totalling $17.1 \%$ of $85 \%$ of the base salary

Length of Study: 3 years

Country of Study: Denmark
Application Procedure: Application must be sent via the electronic recruitment system. The application must include a 5-page project description. This research proposal should contain a presentation of an original research question, a description of the initial theoretical framework and methodology, a presentation of the suggested empirical material as well as a work plan. In addition to the research proposal, the application must include copies of a Master's degree certificate or other certificates of a corresponding level, brief curriculum vitae, a list of papers and publications, and one copy of a selected written work (e.g. Master's thesis)

Closing Date: 28 February

Contributor: Copenhagen Business School

Additional Information: The scholarship requires the student to spend a minimum of 12 months of their PhD programme in a research institution in China. Countries of study are Denmark and China

For further information contact:

Email: dsi.msc@cbs.dk

\section{Core}

3 St Andrew's Place, London, NW1 4LB, United Kingdom.

Tel: $\quad$ (44) 2074860341

Email: info@corecharity.org.uk

Website: www.corecharity.org.uk

Contact: Alice Kington, Finance and Research Manager

\section{Core Fellowships and Grants}

Purpose: To provide funding for gastroenterological research Eligibility: Open to applicants resident within the United Kingdom. Fellowship projects must contain an element of basic science training

Level of Study: Doctorate, Postdoctorate, Postgraduate, Research

Type: Fellowship or Grant

Value: $£ 50,000$ per year salary and $£ 10,000$ per year consumables (Research Fellowships); $£ 50,000$ total (Development Grants)

Length of Study: $1-3$ years

Frequency: Dependent on funds available

Study Establishment: Recognized and established research centres

Country of Study: United Kingdom 
Application Procedure: Applicants must complete an application form for consideration in a research competition. Details are available from the website

No. of awards offered: Varies

Funding: Commercial, Private, Foundation, Trusts, Individuals

Contributor: Charitable donations

No. of awards given last year: 4

No. of applicants last year: Varies

Additional Information: Conditions are advertised on the core website www.corecharity.org.uk serb.gov.in/emr.php

For further information contact:

Email: IAS_applications@ceu.edu

\section{Council of American Overseas Research Centers (CAORC)}

PO Box 37012, MRC 178, Washington, DC 20013-7012, United States of America.

Tel: $\quad$ (1) 2026331599

Email: fellowships@caorc.org

Website: www.caorc.org

Council of American Overseas Research Centers (CAORC) serve as a base for virtually every American scholar undertaking research in the host countries. The members have centres in many locations across the world.

\section{Council of American Overseas Research Centers Andrew W. Mellon East-Central European Research Fellows}

Purpose: To help scholars in the humanities and allied social sciences to carry out research at institutes of advanced study in other countries

Eligibility: Open to candidates who have obtained $\mathrm{PhD}$ and are nationals of Bulgaria, Czech, Estonia, Hungary, Latvia, Lithuania, Poland, Romania or Slovakia

Level of Study: Research

Type: Fellowships

Value: Varies

Length of Study: Short-term residencies

Frequency: Annual

Country of Study: Any country
Additional Information: www.iwm.at/fellowships/formerfellowship-programs/andrew-w-mellon-east-central-europeanresearch-visiting-fellowships/

\section{Council of American Overseas Research Centers Multi-Country Research Fellowship Program for Advanced Multi-Country Research}

Purpose: To advance higher learning and scholarly research and to conduct research of regional or trans-regional significance

Eligibility: Applicants must have obtained a $\mathrm{PhD}$ or be established postdoctoral scholars. The candidate should be a citizen of the United States. Preference will be given to Candidates examining comparative and/or cross-regional research

Level of Study: Doctorate, Postdoctorate, Research

Type: Fellowships

Value: Up to US\$10,500

Frequency: Annual

Country of Study: Any country

Application Procedure: The application can be downloaded from the website. To obtain hard copy of the application, please contact CAORC

No. of awards offered: 120

Closing Date: 20 January

Contributor: United States State Department

No. of awards given last year: 9

No. of applicants last year: 120

Additional Information: Scholars must carry out research in at least one of the countries that host overseas research centres. Please check website for further information einaudi. cornell.edu/opportunity/council-american-overseas-researchcenters-multi-country-research-fellowship

\section{Council of American Overseas Research Centers Neh Research Fellowships}

Purpose: The National Endowment for the Humanities (NEH) Senior Research Fellowship supports advanced research in the humanities. Fellowship awards are for four consecutive months

Eligibility: 1. Applicants must be United States citizens or foreign nationals who have resided in the United States for three years prior to the application deadline. 2. Applicants must be postdoctoral scholars. 3. Funding is not available for research conducted in the United States. 4. It is not required that you be affiliated with a United States academic institution to apply 
Level of Study: Graduate

Type: Fellowship

Value: US\$4,200

Frequency: Annual

Country of Study: Any country

Closing Date: 24 January

Funding: Foundation

\section{Council of Independent Colleges}

One Dupont Circle, N.W, Suite 320, Washington DC 200361142, United States of America.

Tel: $\quad$ (1) 2024667230

Email:_visitingfellows@cic.nche.edu

Website: www.cic.org/projects_services/visitingfellows.asp

Contact: Michelle Friedman, Program Manager

\section{Woodrow Wilson Visiting Fellows}

Purpose: To encourage the flow of ideas between the academic and non-academic sectors of society

Eligibility: The program is available to all four-year public and private, nonprofit colleges and universities in the United States as well as CIC International Member institutions. CIC member campuses participate at a discounted rate.

Level of Study: Postgraduate

Type: Fellowships

Value: STANDARD VISIT: CIC Non-Member Price: US\$6,000, CIC Member Price: US\$5,500 ABBREVIATED

VISIT: CIC Non-Member Price: US\$4,900, CIC Member Price: US $\$ 4,500$

Length of Study: 1 year

Frequency: Annual

Application Procedure: If your campus is ready to start the process of hosting a Fellow, please complete this online form. The form should be completed by a campusdesignated "campus coordinator" who will be CIC's point of contact throughout the planning and execution of the visit. Be prepared to provide a short list of preferred Fellows, preferred time to host a Fellow, preferred visit length, and a brief paragraph about the intended engagement of the Fellow on campus

Closing Date: 17 April

Funding: Private

Contributor: Lilly Endowment

Additional Information: www.cic.edu/member-services/ woodrow-wilson-visiting-fellows

\section{For further information contact:}

Visiting Fellows Program, 5 Vaughn Drive, Suite 300, Princeton, NJ 08540-6313, United States of America.

Tel: (1) 6094527007 ext. 181

Email: sanford@woodrow.org

\section{Council of Logistics Management}

\section{George A. Gecowets Graduate Scholarship Program}

Subjects: Logistics; all programs leading to careers in logistics management

Purpose: To grant scholarships solely on merit - academic achievement, work experience, leadership, and career commitment - rather than financial need.

Eligibility: A student is eligible to apply for this scholarship if they are already enrolled in the first year of a Master's degree program leading to a career in Logistics related graduate program. Type: Scholarship

Value: US $\$ 1,000$

Country of Study: United States of America

Closing Date: 1 April

Additional Information: phdstudents.smeal.psu.edu/ scholarship-fellowship-opportunities/external-awards/gecowets. html

\section{Council of Supply Chain Management Professionals (CSCMP)}

333 East Butterfield Road, Suite 140, Lombard, IL 60148, United States of America.

Tel: (1) 6305740985

Email: membership@cscmp.org

Website: www.cscmp.org

Contact: Kathleen Hedland, Director Education and Roundtable Services

The Council of Supply Chain Management Professionals (CSCMP) is a non-profit organization of business personnel who are interested in improving their logistics management skills. CSCMP works in co-operation with private industry and various organizations to further the understanding and development of the logistics concept. This is accomplished 
through a continuing programme of organized activities, research and meetings designed to develop the theory and understanding of the logistics process, promote the art and science of managing logistics systems, and foster professional dialogue and development within the profession.

\section{Council of Supply Chain Management Professionals Distinguished Service Award}

Purpose: To provide honor to an individual for achievement in supply chain management

Eligibility: All individuals who have made contributions to the field of supply chain management are eligible for the DSA. This includes practitioners with responsibilities in a functional area of supply chain management, consultants and educators-anyone who has made a significant contribution to the advancement of supply chain management. Please check at cscmp.org/career/awards/distinguished-serviceaward-process for more detailed information

Type: Award

Frequency: Annual

Application Procedure: Nominations must be accompanied by a fully completed nomination form and should be emailed to Sue Paulson

Closing Date: 30 April

\section{For further information contact:}

Tel: $\quad$ (1) 6306453469

Email: spaulson@cscmp.org

\section{Council of Supply Chain Management Professionals Doctoral Dissertation Award}

Purpose: To encourage research leading to advancement of the theory and practice to supply chain management

Eligibility: Open to all candidates whose doctoral dissertation demonstrates signified originality and contributes to the logistics knowledge base. See cscmp.org/downloads/public/educa tion/awards/dda-guidelines.pdf for details

Level of Study: Postdoctorate

Type: Award

Value: US\$5,000

Frequency: Annual

Closing Date: May

Additional Information: cscmpedge.org/ehome/344812/ awardsrecognitions/\#DDA

\section{For further information contact:}

Email: kmcinerney@cscmp.org

\section{Supply Chain Innovation Award}

Purpose: CSCMP's Research Strategies Committee (RSC) and Supply Chain Brain established the Supply Chain Innovation Award in 2005 to highlight and recognize the top players in the supply chain industry when it comes to innovative programs, projects and collaboration

Eligibility: The submitting company must be a CSCMP member. In addition, each member of your team must be registered for the annual conference by 1 August. All travel, accommodations, and related expenses are the responsibilities of the finalist teams

Type: Scholarship

Frequency: Annual

Application Procedure: While the finalist teams present their case studies, the panel of judges evaluates the session as it happens live in front of the audience of conference attendees

Funding: Private

Contributor: CSCMP's Research Strategies Committee (RSC) and Supply Chain Brain

Additional Information: Please check complete guidelines at cscmp.org/career/awards/supply-chain-innovation-awardcompetition-guidelines www.eiseverywhere.com/eSites/ 219306/Guidelines

\section{For further information contact:}

Tel: (1) 6306453454

Email: cscmpresearch@cscmp.org

\section{Council on Foreign Relations (CFR)}

The Harold Pratt House, 58 East 68th Street, New York, NY 10065, United States of America.

Tel: $\quad$ (1) 2124349400

Email:_fellowships@cfr.org

Website: www.cfr.org

Contact: Janine Hill, Director, Fellowship Affairs and Studies

The Council on Foreign Relations (CFR) is dedicated to increasing America's understanding of the world and contributing ideas to United States foreign policy. The Council accomplishes this mainly by promoting constructive debates and discussions, clarifying world issues and publishing Foreign Affairs, the leading journal on global issues. 


\section{Council on Foreign Relations International Affairs Fellowship in Japan}

Purpose: To cultivate the United State's understanding of Japan and to strengthen communication between emerging leaders of the two nations

Eligibility: 1. Applicants must be U.S. citizens. 2. Applicants must be mid-career professionals. 3. Applicants must have a strong record of professional achievement. 4. Applicants must have an interest in U.S.-Japan relations. 5. Applicants must hold at least a bachelor's degree. 6. Although the program is intended primarily for those without substantial prior experience in Japan, exceptions have been made when an applicant has demonstrated that the fellowship would add a significant new dimension to his or her career. 7. Knowledge of the Japanese language is not a requirement.

Level of Study: Professional development

Type: Fellowship

Value: Living expenses in Japan plus international transportation, health and travel insurance and necessary research expenses

Length of Study: 3-12 months

Frequency: Annual

Country of Study: Japan

Application Procedure: Application is primarily by invitation, on the recommendation of individuals in academic, government and other institutions who have occasion to know candidates particularly well suited for the experience offered by this fellowship. Others who inquire directly and who meet preliminary requirements may also be invited to apply without formal nomination. Those invited to apply will be forwarded application materials

No. of awards offered: 6

Closing Date: 31 October

Funding: Private

Contributor: Hitachi Limited

No. of awards given last year: 3

No. of applicants last year: 6

Additional Information: While the Fellow is not required to produce a book, article or report, it is hoped that some written output will result. Please check at www.cfr.org/thinktank/ fellowships/iaf japan.html www.cfr.org/fellowships/inter national-affairs-fellowship-japan

\section{For further information contact:}

Fellowship Affairs, Council on Foreign Relations, 58 East 68th Street, New York, NY 10065, United States of America.
Tel:
(1) 2124349740

Fax: (1) 2124349870

\section{Council on Library and Information Resources (CLIR)}

1707 L Street, NW Suite 650, Washington, DC 20036, United States of America.

\author{
Tel: $\quad$ (1) $2029394750 / 4751$ \\ Email: abishop@clir.org \\ Website: www.clir.org \\ Contact: Alice Bishop, Senior Program Officer
}

CLIR is an independent, nonprofit organization that forges strategies to enhance research, teaching, and learning in collaboration with libraries, cultural institutions, and communities of higher learning.

\section{Council on Library and Information Resources Postdoctoral Fellowship}

Purpose: The CLIR Postdoctoral Fellowship Program offers recent $\mathrm{PhD}$ graduates the chance to develop research tools, resources, and services while exploring new career opportunities. CLIR Postdoctoral Fellows work on projects that forge and strengthen connections among library collections, educational technologies, and current research. Host institutions benefit from fellows' field-specific expertise by gaining insights into their collections' potential uses and users, scholarly information behaviors, and current teaching and learning practices

Eligibility: Applicants must have received a $\mathrm{PhD}$ in a discipline no more than five years before applying; if a PhD has not yet been received, all work toward the degree (including dissertation defense and final dissertation editing) must be completed before starting the fellowship. Applicants can be citizens of any country but MUST be legally permitted to work in the United States and/or Canada

Level of Study: Postdoctorate

Type: Postdoctoral fellowship

Value: Varies by host institution

Length of Study: 2 years

Frequency: Annual

Country of Study: United States of America \& Canada Application Procedure: Complete an online application www.clir.org/fellowships/postdoc/applicants/

No. of awards offered: 115

Closing Date: 10 January

Funding: Private, Foundation

Contributor: Alfred P. Sloan Foundation, Andrew W. Mellon Foundation, individual host institutions

No. of awards given last year: 15 
No. of applicants last year: 115

Additional Information: www.postdocs.ubc.ca/award/ council-library-information-resources-postdoctoral-fellowshipprogram

\section{Craig H. Neilsen Foundation}

16830 Ventura Boulevard, Suite 352, Encino, CA 91436, United States of America.

Tel: $\quad$ (1) 8189251245

Website: chnfoundation.org/

Established by Craig H. Neilsen in 2002 as a private foundation, the Craig H. Neilsen Foundation is dedicated to supporting both programs and scientific research to improve the quality of life for those affected by and living with spinal cord injury

\section{Neilsen SCIRTS Postdoctoral Fellowship Grants}

Purpose: The Spinal Cord Injury Research on the Translational Spectrum (SCIRTS) portfolio supports research to improve the understanding of traumatic spinal cord injury and develop new approaches to alleviate the dysfunction and complications that follow. The scope of this portfolio is broad, encompassing mechanistic, preclinical modeling, translational and/or clinical research. These two-year Postdoctoral Fellowships encourage early-career training and specialization in the field of spinal cord injury research.

Eligibility: Applicants must have a doctoral degree or an equivalent terminal professional degree.

Level of Study: Postdoctoral

Type: Fellowships

Value: US\$150,000

Length of Study: Two-year

Frequency: Annual

Closing Date: 5 November

Additional Information: chnfoundation.org/spinal-cordinjury-research-on-the-translational-spectrum/

\section{Craig H. Neilsen Foundation}

\section{Pilot Grants}

Subjects: Aging, caregiving, employment, health behaviors and fitness, independent living, self-management and technology access.
Purpose: This funding is intended to support pilot studies that lay essential groundwork, allow the applicant to test the feasibility of novel methods and procedures and/or collect new data that can lead to or enhance larger-scale studies. Proposed pilot projects should indicate how they will establish a new investigational program or take on 'risk' balanced by high potential impact.

Eligibility: Applicants must have a doctoral degree or other equivalent terminal professional degree, be beyond the postdoctoral level at the time of the FGA submission, and demonstrate appropriate experience to serve as an independent PI.

Type: Grant

Value: Funding for PSR Pilot grants is for up to two years, US $\$ 200,000$ total costs

Length of Study: Two years

Country of Study: Any country

Application Procedure: See website for further details.

Closing Date: 25 March

Additional Information: chnfoundation.org/psychosocialresearch/

\section{Postdoctoral Fellowships}

Subjects: Spinal cord injury

Purpose: To encourage early-career mentored training to increase professional interest in the field and to encourage researchers from related health disciplines to undertake training in psychosocial research focused on spinal cord injury.

Eligibility: Fellows must have attained their doctoral degree or an equivalent terminal professional degree by the FGA submission deadline and have held that degree no longer than five years prior to the FGA submission deadline. For Fellows with an MD degree, the five-year period begins after completion of their residency program. Unique circumstances related to this criterion must be communicated to the Neilsen Foundation for approval prior to submission.

Type: Fellowship

Value: Funding for fellowships is US\$75,000 per year, for up to two years; US\$150,000 total costs.

Length of Study: Two years

Country of Study: Any country

Application Procedure: See website for further details.

Closing Date: 25 March

Additional Information: chnfoundation.org/psychosocialresearch/

\section{Studies and Demonstration Projects}

Subjects: Spinal cord injury

Purpose: This funding is intended to support substantive studies that fill important gaps in the SCI field, that open 
new areas of SCI psychosocial research, or that develop and evaluate interventions to address psychosocial issues after SCI. Submissions in this category should facilitate, expand or improve the translation of knowledge and/or the adoption of interventions and practices that will have a positive impact for those living with SCI. Based within a psychosocial framework, PSR Studies and Demonstration Projects can range from SCI epidemiological studies to interventions that will enhance clinical treatment, rehabilitation, habilitation and/or other related quality of life outcomes.

Eligibility: Applicants must be independent investigators, actively employed at the grantee institution at the time of FGA submission, and can be at any stage of their research career. o Criteria for funding junior investigators include evidence of a research background that is relevant to the proposed study and the mission of the Neilsen Foundation. To establish independence, Applicants who hold a non-tenure track position (Instructor, Research Assistant, etc.) may include, with their Biosketch, a letter of support from the institution's Director or Department Chair at the LOI and FGA stage. Such a letter should confirm the Applicant's position as independent and that all needed space and equipment are available to this PI.

Type: Grant

Value: Funding for PSR Studies and Demonstration Projects is for up to three years, US\$400,000 total costs

Length of Study: Three years

Country of Study: Any country

Application Procedure: See website for further details.

Closing Date: 25 March

Additional Information: chnfoundation.org/psychosocialresearch/

\section{Cranfield University}

School of Applied Sciences, Bedfordshire, MK43 OAL, United Kingdom.

Tel: (44) 1234754086

Email: info@cranfield.ac.uk

Website: www.cranfield.ac.uk/sas

Contact: Vicky Mason, Online Marketing Manager

The School of Applied Sciences is recognized globally for its multidisciplinary approach to teaching and research in the key areas of manufacturing, materials, and environmental science and technology. Our focus is on fundamental research and its application, together with teaching, to meet the needs of industry and society.

\section{Cranfield Global Manufacturing Leadership Masters Scholarship}

Type: Scholarship

Value: Tuition fee plus $£ 1,000$ cash

Country of Study: United Kingdom

Application Procedure: A number of Cranfield's full-time Manufacturing programme MSc courses are applicable to the Global Manufacturing Leadership (GML) Scholarships, please see the course list above. Applicants should submit a normal Cranfield application through the online application system. The online application forms part of the evaluation of academic achievement. Note the 6-digit online application number

Closing Date: 3 April

Funding: Private

Additional Information: www.cranfield.ac.uk/funding/ funding-opportunities/cranfield-global-manufacturing-leader ship-masters-scholarship

\section{For further information contact:}

College Road, Cranfield, MK43 0AL, United Kingdom.

Tel: $\quad$ (44) 1234758181

Email: gmlscholarship@cranfield.ac.uk

\section{Cranfield Merit Scholarship in Leadership and Management}

Eligibility: Sub-Saharan African countries are eligible Type: Scholarship

Value: $£ 4,000$ for tuition fees

Country of Study: United Kingdom

Application Procedure: For application details, send an email to studysom@cranfield.ac.uk

Closing Date: 25 May

Additional Information: worldscholarshipforum.com/ 20182019-cranfield-merit-scholarship-leadership-managementcranfield-university-uk/

\section{For further information contact:}

Email: studysom@cranfield.ac.uk

\section{Cranfield Sub-Saharan Africa Merit Scholarship}

Purpose: To commence full-time study in one of the eligible master courses for the current academic year

Type: Scholarship

Value: $£ 4,000$ for tuition fees

Frequency: Annual 
Country of Study: Any country

Closing Date: 25 May

Additional Information: www.afterschoolafrica.com/

25189/cranfield-sub-saharan-africa-merit-scholarship/

For further information contact:

Email: studysom@cranfield.ac.uk

\section{Global Manufacturing Leadership Masters Scholarships}

Purpose: The scholarships aim to contribute to the education of young professionals with the capabilities required to lead Manufacturing into the future

Eligibility: Applicants can be from any country. Please note Erasmus funded students are not eligible for this scholarship

Type: Scholarship

Value: The scholarship pays for the Cranfield Manufacturing Masters tuition fee and a $£ 1,000$ cash maintenance grant

Country of Study: Any country

Application Procedure: Applicants can be from any country. Please note Erasmus funded students are not eligible for this scholarship

Closing Date: 17 March

Additional Information: www.marj3.com/en/globalmanufacturing-leadership-masters-scholarships-cranfield-uni versity.html

\section{For further information contact:}

Email: gmlscholarship@cranfield.ac.uk

\section{The Diamond Education Grant}

Purpose: Its purpose is to provide grants to assist women to update their skills after employment breaks or to acquire new skills to improve their opportunities for employment and promotion

Type: Grant

Value: Small grants towards tuition fees and other study costs Frequency: Annual

Country of Study: Any country

Application Procedure: Apply online at the Diamond Education Grant website

Closing Date: 15 April

Contributor: Soroptimist International

Additional Information: www.cranfield.ac.uk/funding/ funding-opportunities/diamond-education-grant

\section{For further information contact:}

Soroptimist International Great Britain \& Ireland (SIGBI) Ltd, 2nd Floor, Beckwith House, 1-3 Wellington Road North, Stockport, SK4 1AF, United Kingdom.

Tel: (44) 1614807686

Email: hq@sigbi.org

\section{The Lorch Foundation MSc Student Bursary}

Purpose: To assist postgraduate study

Eligibility: Applicants should be United Kingdom citizens and possess a minimum 2:1 United Kingdom Honours degree in Engineering or Physical Sciences or related discipline, and have been offered a place on the 1-year full-time MSc in Water and Wastewater Engineering or Water and Wastewater Technology

Level of Study: Postgraduate

Type: Bursary

Value: $£ 5,000$ plus tuition fees

Length of Study: 1 year

Frequency: Annual

Study Establishment: Cranfield University, School of Applied Sciences

Country of Study: United Kingdom

Application Procedure: Applicants must apply directly to the university

Closing Date: 31 July

Funding: Foundation

Contributor: The Lorch Foundation

No. of awards given last year: 1

Additional Information: The bursary is provided by the Lorch Foundation, a charitable institution founded to support and promote education and research in the field of water purification and related sciences for the benefit of mankind. The successful applicant will undertake thesis research on processes of water purification and industrial effluent recycling as part of the MSc programme www.cranfield.ac. $\mathrm{uk} /$ funding/funding-opportunities/lorch-foundation-bursaries

\section{For further information contact:}

Tel: (44) 1234758181

Email: studentfunding@cranfield.ac.uk

\section{Water MSc Scholarship for Students from Malawi and Vietnam}

Purpose: The aim of the scholarship is to recruit students across all of our areas of academic specialisms with expertise in a wide range of disciplines to pursue MSc programme 
Eligibility: The scholarship is open to students from Malawi and Vietnam

Value: The Cranfield Water Scholarship provides funding of $£ 6,000$ towards tuition fees

Country of Study: Any country

Closing Date: 25 May

Additional Information: scholarship-positions.com/ cranfield-water-msc-scholarship-students-malawi-vietnamuk/2018/03/15/

\section{For further information contact:}

Email: studywater@cranfield.ac.uk

\section{Women as Cyber Leaders Scholarship}

Purpose: For female students wishing to develop a career in Cyber

Type: Postgraduate scholarships

Value: $£ 6,500$ toward tuition fees

Country of Study: United Kingdom

Application Procedure: For eligibility and application details, please visit website www.cranfield.ac.uk/funding/ funding-opportunities/women-as-cyber-leaders-scholarship

Closing Date: 30 June

Contributor: Cranfield Defence and Security

Additional Information: aseanop.com/women-cyberleaders-scholarship-cranfield-university-uk/

For further information contact:

Email: cdsadmissionsoffice@cranfield.ac.uk

\section{Crohn's and Colitis Foundation of America}

386 Park Avenue South, 17th Floor, New York, NY 10016, United States of America.

Tel: (1) 8009322423

Email: info@ccfa.org

Website: www.ccfa.org/

\section{Crohn's \& Coltis Foundation Career Development Award}

Purpose: To stimulate and encourage innovative research that is likely to increase our understanding of the aetiology, pathogenesis, therapy and preventive of Crohn's Disease and Ulcerative Clotis (IBD)
Eligibility: Candidates should hold an MD, must have 5 years of experience (with 2 years of research relevant to IBD)

Level of Study: Postdoctorate, Research

Type: Fellowship

Value: Not to exceed US $\$ 90,000$ per year

Length of Study: 1-3 years

Frequency: Annual

Study Establishment: Approved research institute

Country of Study: United States of America

Application Procedure: See details at this link: www. crohnscolitisfoundation.org/sites/default/files/2019-06/

CDAGuidelines2019.pdf

Closing Date: 1 July

Funding: Corporation, Foundation, Individuals

Additional Information: www.crohnscolitisfoundation.org/ research/grants-fellowships/career-development-awards

\section{For further information contact:}

Crohn's \& Colitis foundation of America, 386 park avenue south, 17th floor, New York, NY 10016, United States of America.

Tel: (1) $2126853440 / 8009322423$

Email: info@icfa.org

\section{Crohn's \& Coltis Foundation Research Fellowship Awards}

Level of Study: Predoctorate, Research

Funding: Corporation, Foundation, Individuals

Additional Information: www.crohnscolitisfoundation.org/ research/grants-fellowships/research-fellowship-awards

\section{Crohn's \& Coltis Foundation Senior Research Award}

Purpose: To stimulate and encourage innovative research that is likely to increase our understanding of the aetiology, pathogenesis, therapy and preventive of Crohnapos;s Disease and Ulcerative Clotis (IBD)

Eligibility: Applicants should be researchs who hold an MD, $\mathrm{PhD}$ or equivalent

Level of Study: Predoctorate, Research

Type: Research award

Value: Up to US\$100,000 direct cost per year plus indirect cost of $15 \%$ of direct cost (or US\$15,000, whichever is less)

Length of Study: Up to 2 years

Frequency: Annual

Study Establishment: Approved research institute

Country of Study: United States of America 
Application Procedure: All completed applications must include one CD ROM or disk in PDF or word format, one master and four copies collected in order per check list. The complete application must be complied and saved as a single document

Closing Date: 1 July

Funding: Corporation, Foundation, Individuals

Additional Information: www.crohnscolitisfoundation.org/ research/grants-fellowships/senior-research-awards

\section{Croucher Foundation}

Suite 501, Nine Queen's Road Central, Hong Kong.

Tel: $\quad$ (852) 27366337

Email: cfadmin@croucher.org.hk

Website: www.croucher.org.hk

Contact: Ms Elaine Sit, Administrative Officer

Founded to promote education, learning and research in the areas of natural sciences, technology and medicine, the Croucher Foundation operates a scholarship and fellowship scheme for individual applicants who are permanent residents of Hong Kong wishing to pursue doctoral or postdoctoral research overseas. The Foundation otherwise makes grants to institutions only.

\section{Croucher Foundation PhD Scholarships and Postdoctoral Fellowships}

Purpose: Our goal is to identify and support a group of talented Hong Kong students and early-career researchers who, through a process of intensive education and exposure to prominent academics in their respective fields, will develop independent and critical abilities and form enduring collaborative partnerships, to enable them to become next generation of leaders of science, technology and medicine in Hong Kong. Eligibility under the following programmes is restricted to permanent Hong Kong residents

Eligibility: 1. Fellows must be full-time research workers. 2. All applicants must disclose offers of financial support received, or likely to be received, from other sources. Applicants and Fellowship holders must keep the Foundation informed of the progress of applications for support from other sources. Croucher Fellowships are on occasion, and at the discretion of the Foundation as an exception, allowed to be held concurrently with other minor awards. 3. The Foundation occasionally gives approval for Fellows to be remunerated for a limited amount of teaching or research responsibilities but such Fellows must seek approval in advance from the Foundation which may in its absolute discretion modify the terms of the Fellowship

Level of Study: Doctorate, Postdoctorate

Type: Scholarships and fellowships

Value: an annual maintenance allowance has been set to US $\$ 48,240$ per annum. one economy class single air fare and a one-off arrival allowance of US $\$ 1,000$

Length of Study: six years of graduation with a doctoral degree

Frequency: Annual

Country of Study: Any country

Closing Date: 1 November

Funding: Foundation

Additional Information: For further inquiries, check the website croucher.org.hk/funding/study_awards/postdoc toral_fellowships croucher.org.hk/funding/study_awards/ postdoctoral_fellowships

\section{For further information contact:}

Croucher Foundation, Suite 501, Nine Queen's Road Central, Hong Kong.

Fax: (852) 27300742

\section{Croucher Science Communication Studentships}

Purpose: These awards are intended for those engaged in full-time study leading to a Master's degree. Applicants must have obtained at least Second Class Honours Division One in their first degree. Otherwise they must obtain substantively a higher degree by September 2020 to become eligible. Students in their final year of first degree may also apply, but any offer of award will be conditional on their obtaining a suitable qualification upon their graduation by July 2020 .

Eligibility: 1. an annual maintenance allowance which is set at US $\$ 22,400$. 2. one economy class single air fare at both the beginning and end of the period of the award (if awards are tenable overseas); 3 . tuition fees. 4 . a one-off arrival allowance of US $\$ 1,000$ to cover the costs of arriving in a new country during the first year of tenure (if awards are tenable overseas); 5. an academic development allowance of up to US\$2,000 to allow Croucher Studentship recipients to attend conferences, workshops or courses during the tenure of their awards; 6. a medical insurance allowance of up to US $\$ 2,000$ to cover medical insurance costs (if awards are tenable overseas); 7. a family allowance of up to US $\$ 16,000$ for the first child and up to US $\$ 6,800$ for every additional child who resides with the scholar during the entire duration of the award; 8. a commencement award of US $\$ 2,500$ to be offered towards the completion of the Master's degree to contribute towards the cost of travel expenses for family members to attend their graduation ceremonies. 9. a project allowance to 
offer support to those award recipients particularly interested in designing and implementing activities and projects in schools and in the wider community during the tenure of the award and/or the period immediately following the award. Interested scholars are invited to submit proposals to the Foundation for consideration of a programme of activities designed to involve school students, teachers, families and/or other non-specialist audiences in dialogue and debate. Level of Study: Postdoctorate

Type: Studentships

Length of Study: 1 year

Closing Date: May

Additional Information: croucher.org.hk/funding/croucherscience-communication-studentships

For further information contact:

Tel: $\quad$ (852) 27300742

\section{Culinary Trust}

PO Box 5485, Portland, OR 10013, United States of America.

Tel: $\quad$ (1) 972285485

Email: scholarships@theculinarytrust.org

Website: www.theculinarytrust.org/

The Culinary Trust has been the philanthropic partner to over 4,000 members of the International Association of Culinary Professionals (IACP) for over 20 years. The Trust solicits, manages and distributes funds for educational and charitable programmes related to the culinary industry in many areas.

\section{L'Academie de Cuisine Culinary Arts Scholarship}

Purpose: To financially prospective students prospective students for the Culinary Arts Program each year

Eligibility: Open to a student pre-enroled for the 12 months, Culinary Arts or Pastry Arts Certificate Program

Type: Scholarship

Value: US $\$ 5,000$

Length of Study: 1 year

Application Procedure: Check the website for further details Closing Date: December

Additional Information: Scholarship is valid for enrollment during July or October only

\section{For further information contact:}

Tel: (1) 6462246989

\section{The Julia Child Endowment Fund Scholarship}

Purpose: To support a career professional to conduct independent study and research in France, as it relates to French food, wine, history, culture and traditions. This programme also encourages, enables and assists aspiring students and career professionals to advance their knowledge of the culinary arts Eligibility: Open to applicants who have 2 years of food service experience

Level of Study: Professional development

Type: Scholarship

Value: US\$5,000

Frequency: Annual

Country of Study: France

Application Procedure: Applicants are required to include a three-page project proposal, an itemized budget detailing the use of this award, a tentative travel schedule with dates and locations, and provide a current curriculum vitae to qualify for this scholarship

Closing Date: 15 December

Funding: Trusts

Additional Information: Please check website for more details

\section{For further information contact:}

Email: foodwine@bu.edu

\section{Zwilling, J.A. Henckels Culinary Arts Scholarship}

Purpose: To provide financial assistance to students from designated states who are interested in pursuing a degree in the culinary arts

Eligibility: Open to any pre-enroled student, currently enroled student or career professional toward any culinary arts degree or certificate program at any nationally accredited culinary school

Level of Study: Postgraduate

Type: Scholarship

Value: US $\$ 5,000$

Application Procedure: Check the website for further details Closing Date: 15 December

Contributor: Zwilling, J.A. Henckels Trust

\section{Cultural Vistas}

440 Park Avenue South, 2nd Floor (between 29th and 30th Streets), New York, NY 10016, United States of America.

Tel: $\quad$ (1) 2124973500

Email: info@culturalvistas.org

Website: www.culturalvistas.org/ 
CDS International, Inc. is a non-profit organization that administers work exchange programmes. CDS International's goal is to further the international exchange of knowledge and technological skills, and to contribute to the development of a pool of highly trained and interculturally experienced business, academic and government leaders.

\section{Robert Bosch Foundation Fellowship Program}

Purpose: To support young Americans the opportunity to complete a high-level professional development program in Germany

Eligibility: 1. U.S. citizen 2. 40 years of age or younger at the application deadline 3. Minimum five years of relevant, fulltime work experience in target fellowship field (excluding internships) 4. Graduate degree preferred 5. Evidence of outstanding professional performance 6 . Sincere commitment to furthering the transatlantic relationship

Level of Study: Graduate, Unrestricted

Type: Fellowship

Value: Monthly stipend within the range of $€ 3,200$ to 3,700

starting in October; monthly summer stipend of $1.500+$ free accommodations during July, August and September; exact amount of stipend dependent upon number of accompanying dependent family members

Length of Study: 9 months

Frequency: Annual

Application Procedure: 1. Complete application form 2. Resume 3. Official transcripts 4 . 2 page personal statement 5. 2 letters of reference

Closing Date: 15 October

Funding: Private

Additional Information: culturalvistas.org/programs/ abroad/robert-bosch-foundation-fellowship/

\section{For further information contact:}

Email: bosch@culturalvistas.org

\section{Curtin University}

Kent Street, Bentley, Perth, WA 6102, Australia.

\section{Contact: Curtin University}

Curtin University is an Australian public research university based in Bentley and Perth, Western Australia. The university is named after the 14th Prime Minister of Australia, John
Curtin, and is the largest university in Western Australia, with over 58,000 students (as of 2016).

\section{Association of Firearm and Tool Mark Examiners Scholarship}

Purpose: The scholarships listed here are offered to Curtin students by external organisations and individuals (Scholarship Providers) that are not affiliated with Curtin University. Curtin University cannot vouch for the accuracy of the information provided by these scholarship providers. All enquiries should be directed to the relevant scholarship provider

Eligibility: Scholarship is available for pursuing undergraduate and postgraduate degree program

Level of Study: Postgraduate

Type: Scholarship

Value: US $\$ 2,000$

Length of Study: 3 year

Frequency: Annual

Country of Study: Any country

Closing Date: 1 April

Funding: International office

Additional Information: scholarship-positions.com/ association-of-firearm-and-tool-mark-examiners-scholarshipfor-international-students-in-australia/2019/03/12/

\section{For further information contact:}

Email: AFTEScholarship@gmail.com

\section{Three-year Fully Funded PhD Scholarship in Public Health}

Purpose: Curtin University is offering three-year fullyfunded PhD scholarship in Public Health. The scholarship is awarded to conduct health services research that focuses on health systems and implementation science at the School of Public Health

Eligibility: International students can apply for these scholarships. If English is not your first language then you will need to show that your English language skills are at a high enough level to succeed in your studies

Value: The successful candidate will receive a stipend of AU\$27,082 per annum

Study Establishment: Scholarship is awarded to conduct health services research that focuses on health systems and implementation science at the School of Public Health

Country of Study: Australia

Application Procedure: The mode of applying is online 
Closing Date: 9 April

Additional Information: For more details please visit our website scholarship-positions.com/three-year-fully-fundedphd-scholarship-public-health-australia/2018/02/27/

For further information contact:

Email: lynda.bergey@curtin.edu.au

\section{Curtin University of Technology}

Office of Research and Development, GPO Box U1987, Perth, WA 6845, Australia.

Tel: $\quad$ (61) 892669266

Email:_research_scholarships@curtin.edu.au

Website: www.curtin.edu.au/

Curtin University of Technology is a world class, internationally focused, culturally diverse institution. They foster tolerance and encourage the development of the individual. Their programmes centre around the provision of knowledge and skills to meet industry and workplace standards. A combination of first rate resources, staff and technology makes Curtin a forerunner in tertiary education both within Australia and internationally.

\section{American Planning Association(I) - Innovation, Competition and Economic Performance}

Purpose: To encourage students to undertake a Higher Degree by Research within the the Centre for Research in Applied Economics (CRAE)

Eligibility: Candidates must be Australian citizens or permanent residents or New Zealand citizens, should hold or are expected to hold a First Class Honours Degree or its equivalent and must meet Curtin University of Technology's requirements for admission to a $\mathrm{PhD}$.

Level of Study: Graduate

Type: Competition

Value: AU $\$ 25,118$ per year

Length of Study: 3 years with the possibility of an extension of up to 6 months

Application Procedure: Candidates must forward the completed application for admission to a higher degree by research to the Centre for Research into Applied Economics (CRAE)

Closing Date: 31 March

\section{For further information contact:}

Tel: (61) 892662035

Email: H.Bloch@exchange.curtin.edu.au

\section{Australian Biological Resources Study Postgraduate Scholarship}

Purpose: To foster research training compatible with ABRS and national research priorities

Eligibility: Applicants must be Australian citizens or permanent residents, must hold a First or Upper Second Class Honours or equivalent degree in an appropriate discipline and be enroled as a full-time student in a $\mathrm{PhD}$ degree at an Australian institution

Level of Study: Graduate

Type: Scholarship

Value: AU\$22,500

Country of Study: Australia

Application Procedure: Applicants must submit the application to ABRS through the host institution. The application form will then be submitted to the ABRS Advisory Committee for consideration and assessment using the selection criteria. The individual selected as most worthy of funding will be awarded the scholarship

Closing Date: 26 October

Additional Information: scholarships.adelaide.edu.au/ Scholarships/honours/faculty-of-sciences/australian-biologicalresources-study-abrs-national

For further information contact:

Australian Biological Resources Study, GPO Box 787, Canberra, ACT 2601, Australia.

Tel: $\quad$ (61) 262509554

Fax: (61) 262509555

Email: abrs.grants@environment.gov.au

\section{Curtin Business School Doctoral Scholarship}

Purpose: To enable doctoral (PhD, DBA) students to study at the Curtin Business School

Eligibility: Applicants must have completed at least 4 years of tertiary education studies at a high level of achievement and have First/Upper Second Class Honours or equivalent results. See scholarships.curtin.edu.au/scholarship.cfm? id $=52$ for more details

Level of Study: Postgraduate

Type: Scholarship

Value: US $\$ 25,000$

Length of Study: Up to 3 years 
Frequency: Annual

Country of Study: Any country

Application Procedure: Applicants can download the application form and obtain further information from the website Closing Date: 31 December

\section{For further information contact:}

Tel: $\quad$ (61) 892664301

Email: GRS.CurrentStudents@curtin.edu.au

\section{Curtin University Postgraduate Scholarship (CUPS)}

Purpose: To assist with general living costs

Eligibility: Applicants must be Australian or New Zealand citizens or Australian permanent residents and must have completed 4 years of higher education studies at a high level of achievement and must hold, or are expected to obtain, First Class Honours or equivalent results; be enroled in or accepted to enrol in a Higher Degree by Research as a full-time student in the previous year in which the award is to be given

Level of Study: Graduate, Postgraduate

Type: Scholarship

Value: Varies, an annual living allowance of US\$23,728 was given last year. This stipend is indexed annually and is tax-free unless taken on a part-time basis

Length of Study: 2 years for a Master by Research and 3 years, with a possible extension of up to 6 months, for a Doctoral degree

Application Procedure: Check website for further details Closing Date: 31 October

Additional Information: www.australianuniversities.com. au/scholarships/guide/8014-curtin-university-postgraduatescholarship-cups.html

\section{For further information contact:}

Tel: (1) 892664906

Fax: (1) 892663793

\section{Establishing the Source of Gas in Australia's Offshore Petroleum Basins Scholarship}

Purpose: To develop an isotopic method to analyse gases in fluid inclusions and to establish the source of gas in Australia's offshore petroleum basins

Eligibility: Applicants must have First Class Honours or equivalent science degree, preferably in chemistry/geology/ geochemistry. Interests in analytical organic chemistry, laboratory skills in trace analysis, wet chemical methods, GC/GCMS or GC-IRMS instrumentation and awareness of stable isotopic concepts is desirable
Level of Study: Postgraduate

Type: Scholarship

Value: At least US\$20,000 per year

Application Procedure: Check website for further details

Closing Date: 31 December

Contributor: The Stable Isotope and Molecular Biogeochemistry Research Group, Geoscience Australia, GFZ

\section{For further information contact:}

Stable Isotope and Molecular Biogeochemistry Group, Centre for Applied Organic Geochemistry, Department of Applied Chemistry, Curtin University of Technology, GPO Box U1987, Perth, WA 6845, Australia.

Tel: $\quad$ (61) 892662474

Fax: (61) 892662300

Email: K.grice@curtin.edu.au

\section{French-Australian Cotutelle}

Purpose: To support the development of the double doctoral degree Cotutelle' between Australia and France

Eligibility: Applicants must be PhD students (of any nationality) enroled in a Cotutelle project between a French and an Australian university; should not have benefited from the French Embassy Cotutelle grant in previous years and should be registered with FEAST-France

Level of Study: Postgraduate

Type: Grant

Value: US $\$ 2,500$

Application Procedure: Applicants must provide the French Embassy with the completed application form and a copy of the Cotutelle convention

Closing Date: 8 December

For further information contact:

Email: Stephane.GRIVELET@diplomatie.gouv.fr

\section{Hunter Postgraduate Scholarship}

Purpose: To support a $\mathrm{PhD}$ student undertaking research in an area relevant to understanding the causes of Alzheimer's disease

Eligibility: Candidates must be $\mathrm{PhD}$ students undertaking research in an area relevant to understanding the causes of Alzheimer's disease

Level of Study: Postgraduate

Type: Scholarship

Value: Up to NZ\$5,000 towards fees subject to funds available

Length of Study: 1 years 
Application Procedure: Check website for further details Closing Date: 31 October

Additional Information: www.wgtn.ac.nz/scholarships/cur rent/hunter-postgraduate-scholarship

\section{For further information contact:}

Tel: $\quad$ (61) 262547233

Email: aar@alzheimers.org.au

\section{Masters Scholarship in Scotland}

Purpose: The Scottish International Scholarship Programme is targeted at graduates in science, technology and the creative industries, and aims to create lasting connections between Scotland and industry leaders and entrepreneurs across the world

Eligibility: Open to Australian citizens who are presently studing science and technology

Level of Study: Postgraduate

Value: The Scotland Scholarship covers the tuition fee, airfare and a stipend for a taught masters course of up to 12 months duration at any Scottish Institution

Length of Study: Varies

Frequency: Annual

Study Establishment: Any Scottish institution

Country of Study: Scotland

Application Procedure: For more information including application forms please visit: www.gla.ac.uk/

\section{For further information contact:}

Email: scholarships@glasgow.ac

\section{Scots Australian Council Scholarships}

Purpose: To develop lasting links between young Scots and Australians by offering outstanding graduates and young professionals the opportunity to study at a Scottish university

Eligibility: Applicants must be Australian citizens or Australian permanent residents or New Zealand citizens or on permanent Humanitarian Visa. They must be indigenous or Torres Strait Islander students or students with a disability or students from rural or regional areas or mature students or sole parents or current students or prospective students

Level of Study: Postgraduate

Type: Scholarship

Value: $£ 12,000$

Application Procedure: Check website for further details Closing Date: 14 January

Contributor: Scottish universities, Scottish business and industry, British Foreign and Commonwealth Office

\section{For further information contact:}

The Scots Australian Council, 19 Dean Terrace, Stockbridge, Edinburgh EH4 1NL, United Kingdom.

Email: scholarships@scotsoz.org

\section{Sediment and Asphaltite Transport by Canyon Upwelling - Top Up Scholarship}

Purpose: To investigate the role of upwelling currents in transporting material across the continental slope of the Morum Sub-Basin, southern Australia using an integrated geological, oceanographic, and organic geochemical approach

Eligibility: Applicants must be Australian and New Zealand residents, First Class Honours or equivalent science degree holders, preferably in chemistry/geology/geochemistry. Interests in analytical organic chemistry, laboratory skills in trace analysis, wet chemical methods, GC/GCMS or GC-IRMS instrumentation; awareness of stable isotopic concepts is desirable

Level of Study: Graduate

Type: Scholarship

Value: See the organization website

Application Procedure: Applicants must forward their interests, curriculum vitae and names of two referees to Stable Isotope and Molecular Biogeochemistry Group, Centre for Applied Organic Geochemistry, Department of Applied Chemistry

Contributor: The Stable Isotope and Molecular Biogeochemistry Research Group, Adelaide University, a petroleum industry partner

\section{The General Sir John Monash Awards}

Purpose: To enable them to undertake postgraduate study abroad at the world's best universities, appropriate to their field of study

Eligibility: Applicants must be Australian citizens who have graduated from an Australian University with outstanding levels of academic achievement

Level of Study: Postgraduate Research

Type: Award

Value: AU\$70,000 per annum

Length of Study: 3 years

Frequency: Annual

Application Procedure: 1. Be an Australian Citizen; 2. Have completed or be about to complete a full degree from an Australian university, and; 3 . Be planning to undertake postgraduate study at an overseas university commencing in the calendar year following the year of application and selection; 
it is not necessary to have already been accepted to the institution at the time of applying.

No. of awards offered: Between 15 and 20

Closing Date: 10 July

Additional Information: scholarships.adelaide.edu.au/ Scholarships/postgraduate-research/all-faculties/general-sirjohn-monash-awards

\section{For further information contact:}

The General Sir John Monash Foundation, Level 1, Bennelong House, 9 Queen Street, Melbourne, VIC 3000, Australia.

Tel: (61) 61396202428

Email: peter.binks@monashawards.org

\section{Water Corporation Scholarship in Biosolids Research}

Purpose: To investigate the potential impacts to soil and plants following the agricultural land application of alumdosed wastewater sludge

Eligibility: Applicants must be Australian Citizens, Australian permanent residents or must hold an Australian permanent Humanitarian Visa. They must hold a relevant degree from a recognized University in the preferred fields of Agriculture, Environmental Science or the equivalent and demonstrate a high level in their Honours project or equivalent

Level of Study: Graduate, Postgraduate

Type: Scholarship

Value: US\$23,400 per year

Length of Study: 3 years for a doctoral program and 2 years for a masters program

Application Procedure: Check website for further details Closing Date: 31 October

\section{For further information contact:}

Email: D.Pritchard@curtin.edu.au

\section{Cystinosis Research Foundation}

\section{Postdoctoral Research Fellowships}

Subjects: Cystinosis research

Purpose: The ultimate goal of the Cystinosis Research Foundation is to find better treatments and a cure for cystinosis. Research and fellowship applications must take into consideration the mission and goals of the foundation in order to be considered.

Eligibility: First priority will be given to 'named' postdoctoral trainees. However, investigators who are already studying cystinosis can apply for a fellowship position with the expectation of attracting a suitable postdoctoral fellow within a year. Pre-doctoral students, who are already studying cystinosis, will be considered if funding is available.

Type: Fellowship

Value: Max. US\$75,000 per year

Length of Study: One to two years

Frequency: Annual

Country of Study: Any country

Application Procedure: Maximum length is six one-sided pages, single-spaced, using a standard 12-point font with 1-inch margins $(2.54 \mathrm{~cm})$ on all sides including figures, diagrams and drawings. Cover sheet, documentation, budget and budget justification and curriculum vitae (CV limit is 5 pages maximum or a bio sketch) are not included in the 6-page limit. Longer applications will not be evaluated.

Closing Date: 20 April

Additional Information: Fellowship applications must provide a $\mathrm{CV}$ (maximum of 5 pages) of the proposed candidate and a statement outlining his/her career goals. Please discuss why this fellowship is important to the applicant. It should be clear who the fellow's mentor(s) will be. The mentor must provide a $\mathrm{CV}$ (maximum of 5 pages) or a bio sketch as well as a statement of the plan for training the fellow. www.cystinosis research.org/research/for-researchers/

\section{Research Proposals}

Subjects: Cystinosis research

Purpose: The ultimate goal of the Cystinosis Research Foundation is to find better treatments and a cure for cystinosis. The Cystinosis Research Foundation is prepared to fund proposals to improve the immediate care of children and adults with cystinosis and to develop a new understanding and treatment of cystinosis in an effort to help these patients in the future.

Eligibility: No limitations to eligibility

Type: Research grant

Length of Study: One to two years

Frequency: Annual

Country of Study: Any country

Application Procedure: Maximum length is nine one-sided pages, single-spaced, using a standard 12-point font with 1-inch margins $(2.54 \mathrm{~cm})$ on all sides including figures, diagrams and drawings. Cover sheet, documentation, budget and budget justification and curriculum vitae (CV limit is 5 pages maximum or a bio sketch) are not included in the 9-page limit. Longer applications will not be evaluated.

Closing Date: 20 April

Additional Information: Applicants must submit the original completed application, nine (9) printed copies of each proposal and an electronic copy (PDF format if possible) www.cystinosisresearch.org/research/for-researchers/ 